\title{
Comprehensive assessment of impulsivity in alcohol use and gambling disorders
}

\author{
Ildikó Kovács \\ Ph.D. Thesis
}

Szeged

2020 


\title{
Comprehensive assessment of impulsivity in alcohol use and gambling disorders
}

\author{
Ph.D. Thesis
}

Ildikó Kovács, M.A.

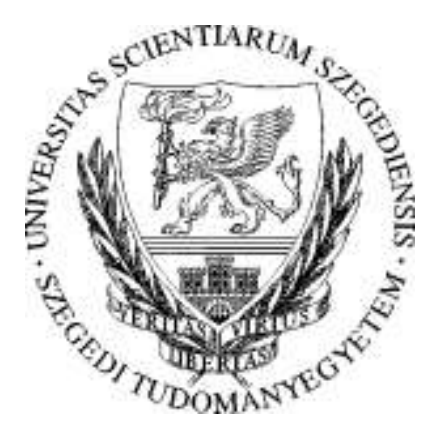

Doctoral School of Clinical Medicine

Department of Psychiatry

Albert Szent-Györgyi Clinical Centre

Faculty of Medicine

University of Szeged

Supervisors:

Zoltán Janka, M.D., Ph.D., D.Sc.

professor emeritus

Department of Psychiatry, Faculty of Medicine, University of Szeged

Bálint Andó, M.A., Ph.D.

senior lecturer

Department of Psychiatry, Faculty of Medicine, University of Szeged

Szeged 


\section{Original research articles related to the thesis:}

I. Andó, B., Kovács, I., Janka, Z., \& Demetrovics, Zs. (2016). Szerencsejáték-használati zavar és alkoholhasználat-zavar - hasonlóságok és különbségek. Psychiatria Hungarica, 31(2), 169-175.

II. Kovács, I., Richman, M.J., Janka, Z., Maraz, A., \& Andó, B. (2017). Decision making measured by the Iowa Gambling Task in alcohol use disorder and gambling disorder: a systematic review and meta-analysis. Drug and Alcohol Dependence, 181, 152-161. IF: 3.322

III. Kovács, I., Demeter, I., Janka, Z., Demetrovics, Zs., Maraz, A., \& Andó, B. (2020). Different aspects of impulsivity in chronic alcohol use disorder with and without comorbid problem gambling. PLOS One 15(1): e0227645, DOI: 10.1371/journal.pone.0227645. IF 2019: 2.776

Cumulative impact factor of the original papers related to the thesis: 6.098

\section{Conference abstracts related to the thesis:}

I. Kovács, I. (2017). Impairment of decision making measured by the Iowa Gambling Task in alcohol dependence and gambling disorder: A systematic review and metaanalysis. $4^{\text {th }}$ International Conference on Behavioral Addictions, 20-22 February, Haifa, Israel.

II. Kovács, I. (2016). From behavioural addictions to substance related disorders: neurocognitive aspects of impulsivity. ECNP Seminar in Neuropsychopharmacology, 7-9 October, Budapest, Hungary.

III. Kovács, I., Demeter, I., Demetrovics, Zs., Janka, Z., Maraz, A., \& Andó, B. (2019). Impulsivity as risk factor for comorbid problem gambling in chronic alcohol use disorder patients: a clinical exploratory study. 32nd ECNP Congress, 7-10 September, Copenhagen, Denmark.

IV. Kovács, I., Richman, M., Janka, Z., Maráz, A., \& Andó, B. (2017). Characteristics of cognitive impulsivity in alcohol use and gambling disorder: a meta-analysis on decision making assessed with the Iowa Gambling Task. 30th ECNP Congress, 2-5 September, Paris, France. 


\section{Table of contents}

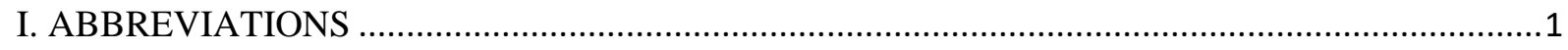

II. SCOPE AND AIM OF THIS WORK

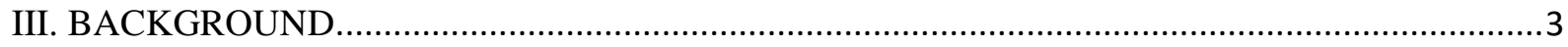

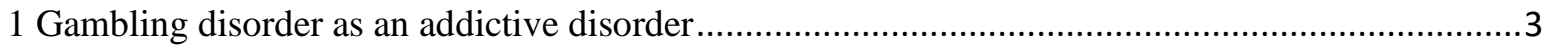

1.1 Epidemiology of gambling disorder and alcohol use disorder ................................................

1.2 Comorbidity of alcohol use disorder and gambling disorder ...............................................

2 Similarities in the symptomatology of alcohol use and gambling disorder...................................5

3 Common features in aetiology, comorbid psychiatric disorders and prognosis in AUD and GD ....8

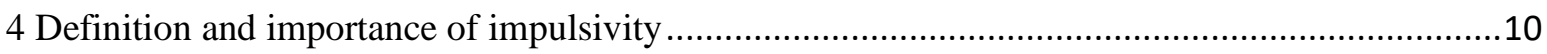

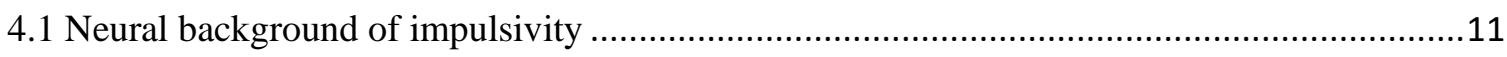

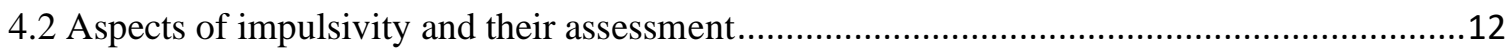

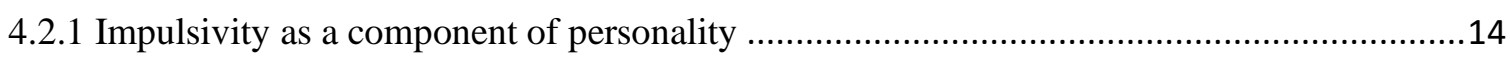

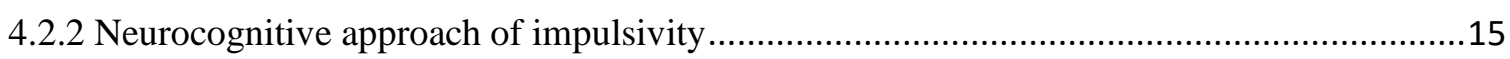

5 Importance of impulsivity in alcohol use and gambling disorder ..............................................17

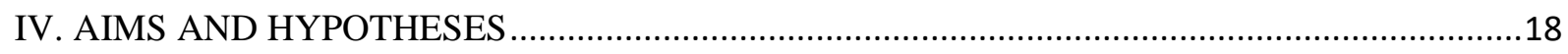

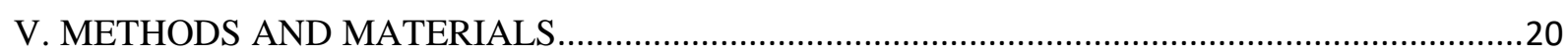

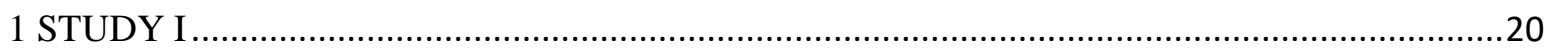

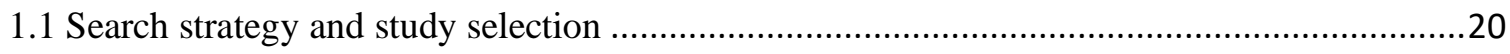

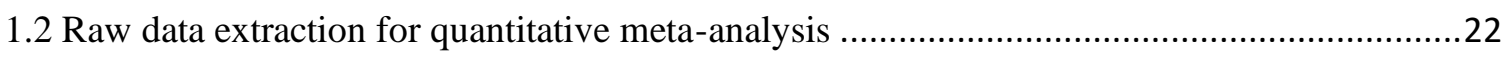

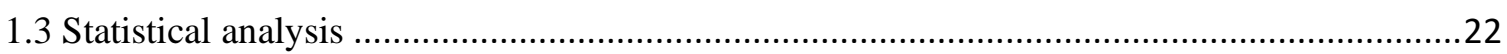

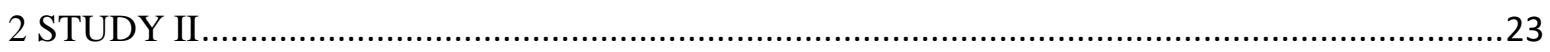

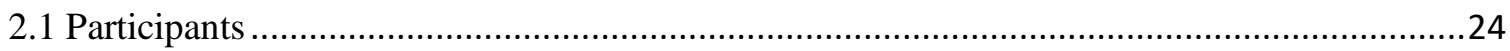

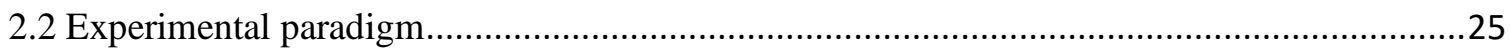

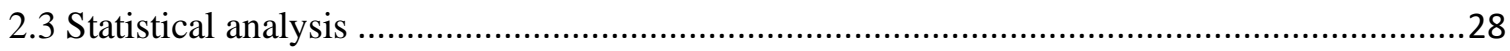

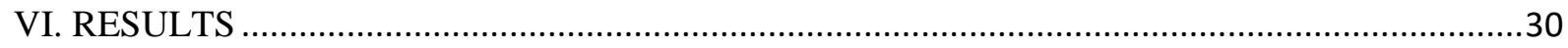

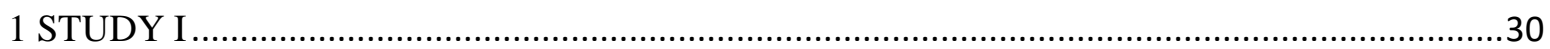

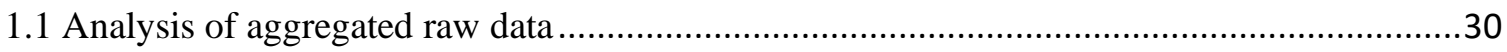

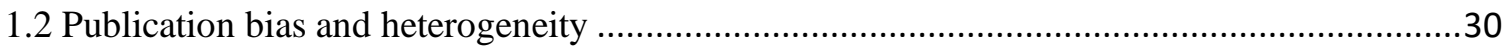

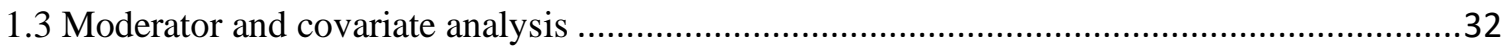

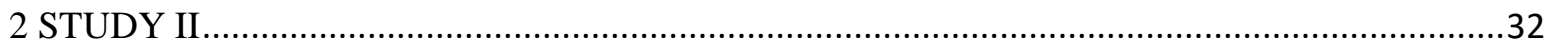

2.1 Demographic data and prevalence of gambling disorder symptoms in the sample .................32

2.2 Exploratory correlation matrix and group differences between gambling symptom severity and demographic variables, psychopathological symptoms and measures of impulsivity .............33

2.3 The effect of demographic variables, psychopathological symptoms and measures of impulsivity on gambling symptoms 
VII. DISCUSSION.

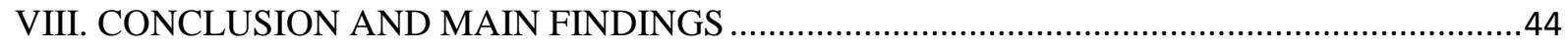

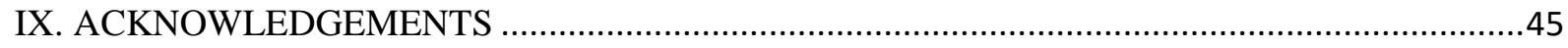

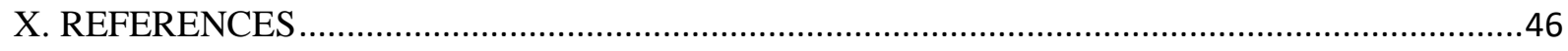

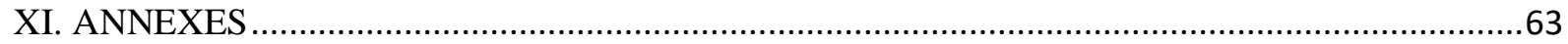


I. ABBREVIATIONS

ASI

AUD

AUDIT

BIS

BPAQ

CMA

DDT

DSM

GD

$\mathrm{HC}$

ICD

IGT

M

PRISMA

SCL-90-R

SD

SOGS

OR

VIF

WAIS

WCST
Addiction Severity Index

Alcohol Use Disorder

Alcohol Use Disorder Identification Test

Barratt Impulsiveness Scale

Buss-Perry Aggression Questionnaire

Comprehensive Meta-Analysis Software

Delay Discounting Task

Diagnostic and Statistical Manual of Mental Disorders

Gambling Disorder

Healthy Control

International Classification of Diseases

Iowa Gambling Task

Mean

Preferred Reporting Items for Systematic Review and Meta-Analysis

Symptom Checklist-90-Revised

Standard Deviation

South Oaks Gambling Screen

Odds Ratio

Variance Inflation Factor

Wechsler Adult Intelligence Scale

Wisconsin Card Sorting Test 


\section{SCOPE AND AIM OF THIS WORK}

The fifth edition of the Diagnostic and Statistical Manual of Mental Disorders (DSM5) introduced a novel approach in the classification of addictive disorders, since Gambling Disorder (GD) was reclassified from Impulse Control Disorders into Substance-Related and Addictive Disorders as the first and yet the only non-substance-related addiction. Scientific literature indicates that from substance-related addictions, alcohol use disorder (AUD) shows the highest comorbidity with GD. It is also highlighted that GD displays similar features to substance-related disorders, thus AUD, in terms of clinical expression, comorbidity, physiology, brain origin and treatment prognosis. Although the background and characteristics of these disorders separately have been assessed for decades, data on features of concomitant AUD and GD are scarce, which underlines the paramount importance of examining the two disorders jointly. For this purpose, our aim was firstly to review the similarities of AUD and GD, from which higher impulsiveness was pointed out as a core feature in both disorders. Then, in the framework of a systematic review-based meta-analysis, aggregated clinical data was analysed concerning cognitive impulsivity in AUD and GD patients contrasted with healthy controls. Moreover, different aspects of impulsivity were investigated in AUD patients with or without comorbid GD symptoms to assess whether the comorbidity of these two disorders are accompanied by more severe impulse control deficits.

The main goals of the studies comprising the present thesis were the following:

I. To assess similarities and differences between alcohol use disorder and gambling disorder.

II. To differentiate patients diagnosed with alcohol use disorder, gambling disorder and healthy matched controls in terms of cognitive impulsivity measured by the Iowa Gambling Task.

III. To evaluate the comorbidity of gambling disorder symptoms in alcohol use disorder patients receiving inpatient treatment.

IV. To investigate whether concomitant gambling disorder symptoms in chronic alcohol use disorder patients is accompanied by more severe impulse control deficiencies. 


\section{BACKGROUND}

\section{Gambling disorder as an addictive disorder}

Novel findings of studies conducted in the fields of neurology, neurobiology, genetics, epidemiology and behavioural sciences clarify and transform our knowledge about mental disorders, which forms the basis of the constant development and refinement of the Diagnostic and Statistical Manual of Mental Disorders (American Psychiatric Association, 2013). The novel fifth edition of DSM introduced several major changes in the diagnostic criteria, from which the reclassification of gambling disorder (GD) from Impulse Control Disorders to Substance-Related and Addictive Disorders is prominent.

GD, with the name of pathological gambling, has been introduced in the third version of the DSM as a standalone diagnostic category, and has previously been considered an impulse control disorder, though subsequently, literature highlighted that it has several common characteristics with substance use disorders, which resulted in its recategorization. A change in the name of the disorder has been introduced with the aim of reducing social stigmatization, and additionally, like other substance-related addictive disorders, it has also been treated as a spectrum disorder, ranging from social-recreational (in cases nonproblematic) use to addictive behaviour (Denis, Fatséas \& Auriacombie, 2012; Reilly \& Smith, 2015; Stron \& Kahler, 2007). While GD is highly comorbid with many systemic diseases and is often present concomitantly with other mental disorders (Bischof et al., 2015; World Health Organization, 2018), its co-occurrence with other substance-related addictive disorders are predominant, from which the highest comorbidity is documented with alcohol use disorder (Petry et al., 2005).

\subsection{Epidemiology of gambling disorder and alcohol use disorder}

Over the past decades, several studies have been conducted worldwide to address the prevalence of GD. A meta-analysis of 120 empirical studies based on the populations of North America concluded that $1.6 \%$ of the adult population met the DSM diagnostic criteria of GD during at least one point of their lifetime (Shaffer et al., 1999). In a representative study of US population, the lifetime prevalence of GD was found to be slightly lower (0.9\%). Age found to be a dominant factor, since the prevalence rate for adolescents under the age of 18 was $3.9 \%$, with a past year rate of $5.8 \%$ compared to adults' $1.1 \%$ (Shaffer \& Hall, 1996). Similarly, another meta-analysis of 34 empirical studies of New Zealand and Australia indicated similar prevalence rates of the appearance of GD in the population (Storer, Abbott \& Stubbs, 2009). 
Regarding population-based data from Europe, Kun et al. (2011) conducted a systematic review of literature based on nationally representative data available from European countries, where the lifetime prevalence rates of problem and pathological gambling were between $1.1 \%$ and 6.5\%. In Hungary, Paksi et al. (2009) conducted a nationally representative study on GD of 2,710 individuals aged between 18 and 64 . They reported that the prevalence of problem gambling was $1.9 \%$ in the population, while pathological gambling was $1.4 \%$. Problem and pathological GD was higher in men (5.3\%), in younger adults aged between 18 and $24(5 \%)$ and in participants coming from a lower income household (2.4\%).

Concerning AUD, according to the results of the National Comorbidity Survey, the lifetime prevalence of alcohol abuse and AUD were $14.2 \%$ and $9.4 \%$ respectively. Mean age of onset was 18 years, while the risk of developing lifetime AUD increased in cases of start of drinking before the age of 17 (lifetime prevalence rate of 24.5\%) (Kessler et al., 1997). The most recent data from the National Epidemiologic Survey on Alcohol and Related Conditions study conducted in the United States indicated a slightly increasing tendency: the past year prevalence of AUD was $13.9 \%$, while the lifetime prevalence was $29.1 \%$. Prevalence of AUD was higher among men (36.0\% versus $17.6 \%$ in women), among younger participants (37.0\%) (Hasin \& Grant, 2015). In Europe, available population surveys indicated that the cumulative rate of the past year prevalence of AUD was $8.8 \%$, with a lifetime prevalence of $5.3 \%$, with a 5-times greater odds ratio for men in case of lifetime prevalence $(\mathrm{OR}=5.3)$ (Muñoz et al., 2018). For Hungary, data indicate a past 12-month prevalence rate of $11.7 \%$ and a $24.5 \%$ lifetime prevalence of AUD (Rehm et al., 2015).

\subsection{Comorbidity of alcohol use disorder and gambling disorder}

In this work, GD was selected for comparison, since it showed the highest comorbidity of any substance-related disorder with AUD. Studies have reported that AUD and GD are highly comorbid both in community (Cunningham-Williams et al., 1998; Manning et al., 2017) and in treatment seeking (Feigelman et al., 1998; Stinchfield et al., 2005) samples as well.

Concerning community-based samples, in a national study of 43,000 individuals conducted in the US, almost three-quarters (73.2\%) of lifetime GD patients also met the criteria of AUD (Petry et al., 2005), while in a population-based meta-analysis, it was reported that $28 \%$ of lifetime GD patients had AUD as well (Lorains et al., 2011), and other studies conducted in the USA, Australia and Western Europe reported a 17-33\% comorbidity 
of concurrent GD and AUD (Daghestani et al., 1996; Lesieur et al., 1991). Welte et al. (2001) highlighted a significant connection between AUD and GD, and it was also reported that greater daily alcohol intake was associated with more frequent and more intense gambling activity. In another population-based study of 14,934 individuals, it was shown that people with AUD were 2.9 times more likely to develop moderate or even heavy GD problems (ElGuebaly et al., 2006).

In treatment seeking populations, $15 \%$ of AUD patients met the diagnostic criteria of having GD during their lives, while $10.9 \%$ of them had concurrent GD at the time of their treatment (Cowlishaw et al., 2014). Concerning outpatient treatment, a study reported that $19 \%$ of treatment-seeking AUD patients showed problem gambling symptoms measured by the South Oaks Gambling Scale (SOGS), and 4\% of them met the diagnostic criteria of fullblown GD (Sellman et al., 2002). These data indicate that the prevalence of comorbid GD in AUD is much higher than the prevalence rates of $0.5-2 \%$ reported in general populations (Colishaw et al., 2014; Kessler et al., 2008; Petry et al., 2005). Parallelly, the elevated rates of comorbid AUD in patients seeking treatment for GD also highlight the importance of addressing the associations of these two disorders. In one study, Ibáñez et al. (2001) found that $23.2 \%$ of GD patients also met the DSM criteria of current AUD, while Grant \& Kim (2001) reported on a large sample that $27 \%$ of treatment-seeking GD patients met the diagnostic criteria of lifetime AUD.

\section{Similarities in the symptomatology of alcohol use and gambling disorder}

DSM-5 lists AUD and GD as Substance-Related and Addictive Disorders. A comparison of the diagnostic criteria of both disorders are presented in Table 1, matching criteria are listed side by side.

Table 1: Comparison of DSM-5 diagnostic criteria of alcohol use disorder and gambling disorder (numbers in parenthesis are the numbering of the DSM-5) (American Psychiatric Association, 2013)

\begin{tabular}{ll}
\multicolumn{1}{c}{ Alcohol Use Disorder } & \multicolumn{1}{c}{ Gambling Disorder } \\
\hline $\begin{array}{l}\text { Alcohol is often taken in larger amounts or } \\
\text { over a longer period than was intended (1) }\end{array}$ & \\
\hline $\begin{array}{l}\text { There is a persistent desire or unsuccessful } \\
\text { efforts to cut down or control alcohol use (2) }\end{array}$ & Has made repeated unsuccessful efforts to \\
control, cut back, or stop gambling (3)
\end{tabular}


Craving, or a strong desire or urge to use alcohol (4)

Recurrent alcohol use resulting in a failure Has jeopardized or lost a significant to fulfil major role obligations at work, school, or home (5)

Continued alcohol use despite having relationship, job, or educational or career opportunity because of gambling (8) persistent or recurrent social or interpersonal problems caused or exacerbated by the Has jeopardized or lost a significant relationship, job, or educational or career opportunity because of gambling (8) effects of alcohol (6)

Important social, occupational, or recreational activities are given up or reduced because

of alcohol use (7)

Recurrent alcohol use in situations in which it is physically hazardous (8)

Alcohol use is continued despite knowledge of having a persistent or recurrent physical or psychological problem that is likely to have been caused or exacerbated by alcohol (9)

Tolerance (10)
Has jeopardized or lost a significant relationship, job, or educational or career opportunity because of gambling (8)

\begin{tabular}{ll}
\hline Tolerance (10) & $\begin{array}{l}\text { Needs to gamble with increasing amounts of } \\
\text { money in order to achieve the desired } \\
\text { excitement (1) }\end{array}$ \\
\hline Withdrawal (11) & $\begin{array}{l}\text { Is restless or irritable when attempting to cut } \\
\text { down or stop gambling (2) }\end{array}$ \\
\hline Is often preoccupied with gambling (4) \\
\hline Often gambles when feeling distressed (5) \\
\hline $\begin{array}{l}\text { After losing money gambling, often returns } \\
\text { another day to get even (6) }\end{array}$ \\
\hline $\begin{array}{l}\text { Lies to conceal the extent of involvement } \\
\text { with gambling (7) }\end{array}$ \\
$\begin{array}{l}\text { Relies on others to provide money to relieve } \\
\text { desperate financial situations caused } \\
\text { by gambling (9) }\end{array}$ \\
\hline
\end{tabular}

Footnote: specification of current severity in case of AUD: mild - presence of 2-3 symptoms; moderate presence of 4-5 symptoms; severe - presence of 6 or more symptoms. Specification of current severity for GD: mild - 2-3 criteria met; moderate $-6-7$ criteria met; severe $-8-9$ criteria met

It is visible that the diagnostic criteria of GD show a significant overlap with the diagnostic criteria of AUD. It is important to note that in cases where criteria are not equivalent to each other, mutuality is also present on a symptomatic level. Thus, the criteria of "great deal of time spent in activities necessary to obtain or use alcohol" or "craving" are not explicitly displayed in case of GD, however they present an integral part of the symptomatic picture of the disorder. Along with aspects of decreased work performance, existential problems and interpersonal disadvantages, empirical studies confirmed that people affected by GD 
experience craving (Koob, 2000; Tavares et al., 2005), withdrawal symptoms (Blaszczynski et al., 2008), tolerance (Griffith, 1993) and frequent relapse episodes (Braun et al., 2014; Ledgerwood \& Petry, 2006) as well. These clinical aspects are also considerable features in AUD (common clinical symptoms of the two disorders are listed in Table 2).

Table 2: Similarities in clinical symptoms of alcohol use disorder and gambling disorder

\begin{tabular}{c} 
Alcohol Use Disorder \\
\hline Tolerance \\
Craving \\
\hline Withdrawal symptoms \\
\hline High comorbidity both in adolescents and in adults \\
\hline Existential/work-related disadvantages \\
\hline High relapse rate \\
\hline Low treatment participation \\
\hline Loss of control \\
\hline Disfunctions in disinhibitory control
\end{tabular}

Higher impulsivity

The emergence of tolerance has been documented both in AUD and GD. Tolerance, as the necessity to increase doses of alcohol/gambling activity to reach a similar effect, plays a key role in maintaining the addictive cycle. Griffith (1993) examined biological parameters reflecting on tolerance of regular and non-regular gamblers, and highlighted that gamblers adapt to the gambling activity on a physiological level. In order to reach similar psychological and physiological state, the amount of time spent with gambling and the value of the gamble needed to be extended. This phenomenon can be paralleled with tolerance documented in AUD.

The phenomenon of craving is presented in both AUD and GD, which can be defined as a strong desire to pursue alcohol/gambling, or the memory of a positive/pleasant experience with them which supersede negative experiences (Koob, 2000). In a study, Duvarci and Varan (2000) compared GD patients with subclinical (i.e. frequent but nonpathologic) gamblers, where GD patients reported more frequent cravings, while Tavares et al. (2005) reported that GD patients experienced even stronger cravings compared to AUD patients.

Similar to AUD, the development of withdrawal symptoms is also documented in GD. Blaszczynski et al. (2008) documented that gamblers reported elevated levels of arousal and upon gambling cessation, they experienced physiological reactions of withdrawal. While Rosenthal and Lesieur (1993) reported that 65\% of GD patients exhibited at least one 
symptom of withdrawal (insomnia, high palpitation, physical weakness, muscle cramps or aches, difficulty of breathing, chills or sweating). In another study, 30-40\% of GD participants experienced severe behavioural and mood symptoms similar to the psychological and physiological symptoms that can be observed in case of AUD: low mood, irritability, motor agitation, tremor, problems in focusing attention and concentration (Wray \& Dickerson, 1981).

Existential problems like the neglection of social and/or work relationships, extensive loss of money, higher divorce rates have also been associated with both AUD and GD (Blaszczynski, 2010; Kalischuk, 2010). Also, loss of control and subsequently the emergence of multiple relapses are common in both disorders. Studies demonstrated that similar psychological, biological and social/environmental factors lead to relapse in AUD and GD, which are the following: similar personality traits (neuroticism and extraversion), cognitive distortions (having the illusion of sense of control in alcohol intake/gambling activity), coping mechanisms (use of maladaptive coping mechanisms in stressful situations) and personality traits (neuroticism, higher sensation seeking) (Ledgerwood \& Petry, 2006).

Despite the high prevalence and several adverse consequences associated with AUD and GD, many people affected by them do not seek treatment. In a large nationally representative study conducted in the US, in the first year after disease onset, only $5 \%$ of AUD patients sought treatment, while the lifetime probability of treatment seeking patients who did not remit was only 54\% (Blanco et al., 2015). It is similar in the case of GD, despite the often debilitating nature of the disease, it is less than $10 \%$ of GD patients who seek treatment (Braun et al., 2014).

Deficits in disinhibitory control has also been linked to both AUD and GD. In a study, patients showing symptoms of both disorders showed higher levels of risk taking (Ledgerwood et al., 2009), while multiple studies indicated that shared deficit of decisionmaking was reported in patients with AUD and with GD compared to healthy controls (Goudriaan et al., 2005; Lawrence et al., 2009). Moreover, the investigation of clinical and subclinical populations led to highlighting the interconnectivity of AUD, GD and impulsivity.

\section{Common features in aetiology, comorbid psychiatric disorders and prognosis in AUD and} GD

It is visible from above that cross-sectional attributes and symptoms are similar in both AUD and GD; moreover, examined from a longitudinal perspective, the two disorders also share similarities. In case of AUD and GD, higher impulsivity is shown to be a common 
symptom in both disorders, but literature suggests that accompanied with deficits in inhibitory control, elevated level of impulsiveness precedes the actual onset of the addictive disorder, thus can be regarded as a vulnerability factor for the emergence of the addiction itself (Slutske et al., 2013). As a potential interpretation for impulsivity simultaneously present as a symptom and an aetiological factor is that it is hypothesized that individuals with addictive disorders are originally more impulsive, which intensifies addiction (Verdejo-García, Lawrence \& Clark, 2008).

Three risk groups can be differentiated being more prone to the development of addictive disorders: 1) adolescents are more vulnerable for the emergence of addiction; 2) clinical groups expressing externalizing behavioural disorders (e.g. attention deficit hyperactivity disorder or conduct disorder) and 3) children of parents diagnosed with addictive disorders are also genetically prone to develop addiction (Holden, 2010). It is documented that AUD and GD are comorbid even in adolescents (Dussault et al., 2011; Verdejo-García et al., 2008), which also accentuates the existence of a shared aetiological background. This was thoroughly evaluated in twin studies, where twins with the diagnosis of GD had an eight times higher chance to have AUD in their history compared to twins without the diagnosis of GD. The co-occurrence of comorbid AUD is highly present in case of both monozygotic and dizygotic twins even with subclinical GD symptoms: $50.4 \%$ for monozygotic and $44.3 \%$ for dizygotic twins compared to $33.5 \%$ and $35 \%$, respectively, for non-GD twins (Slutske et al., 2014).

Strong associations have been documented with comorbid mental disorders in case of AUD and GD as well. Concerning GD, studies have also associated GD with symptoms of somatic ill-health, problems with sleep, loss of appetite, higher levels of stress and suicide (Cunningham-Williams et al., 2000; Morasco et al., 2006). In case of mental problems, a large study including 6510 individuals showed that $79.1 \%$ of GD patients had a comorbid psychiatric disorder, from which other substance-related problems, affective problems, anxiety disorder and suicidal risk were the most predominant (Park et al., 2010). Metaanalytical assessment also reported the high co-occurrence of GD and other substance use disorders (57,5\%), affective disorders (37.9\%) and anxiety disorders (37.4\%) (Lorains et al., 2011). Regarding AUD, vast literature established a causal link with AUD several mental illnesses. One population-based study addressed DSM Axis I and II problems co-occurring with AUD and reported strong association with mood disorders (OR: 2.20-2-71), anxiety disorders (OR: 2.11-2.61) and personality disorders (OR: 2.52-3.11) (Hasin et al., 2007). 
A predominant feature of both disorders is their association with chronic relapse problems over the lifetime (Evren et al., 2012; Ledgerwood \& Petry, 2006). Recent clinical trials have proven that the same pharmacotherapeutic approach had positive outcomes in case of both GD and AUD (Tamminga \& Nestler, 2006), while it is indicated that the concomitant appearance of both disorders influence treatment prognosis as well. In one study, characteristics of alcohol use were examined in treatment-seeking GD patients, and it was documented that the quantity of alcohol consumption gradually decreased for the first period during the course of treatment, but afterwards this tendency of decrease disappeared and $31 \%$ of the sample indicated excessive, problematic use of alcohol (Rash, Weinstock \& Petry, 2011). Parallelly, in another study assessing the gambling activity of treatment-seeking AUD patients showed that the more severe AUD correlated with higher levels of GD symptoms, and concomitantly they showed a significant positive correlation with more severe psychopathological symptom severity (Stinchfield, Kushner \& Winters, 2005).

\section{Definition and importance of impulsivity}

Impulsivity is regarded as a core feature in addictive disorders, thus AUD and GD, since many of the diagnostic criteria of both disorders may also be interpreted in the framework of impulsivity or may be related to it. In this sense, regardless of the perceived harm resulting from the pursue of drinking/gambling behaviour, prolonged gambling activity/alcohol consumption, unsuccessful attempts to cut back or seize the pursuit if these actions, with the repeated failure to withdraw from them may also be linked to malfunctions of behavioural disinhibition, the disfunction of inhibitory control, i.e. forms of impulsivity (American Psychiatric Association, 2013; Kozak et al., 2018; Verdejo-Garcia, et al. 2008).

On this notion, defining the concept of impulsivity is actually quite difficult, since it is regarded as a manifold, multifaceted construct consisting of several related subdomains and is regularly grasped as the repeated performing of maladaptive behavioural actions resulting in probable negative consequences. In this sense, impulsive actions may be considered as rapid and unplanned reactions to internal or external stimuli with the aim of achieving immediate pleasure and/or gratification (Bottesi et al., 2014; Verdejo-García et al., 2008). Recent understandings of impulsiveness underline the importance of not just the behavioural aspects of impulsivity, but also their underlying neurobiological and neuropsychological components (Ioannidis et al., 2017; Rochat et al., 2018; Stephan et al., 2017).

As described previously, AUD and GD not only share elevated levels of impulsiveness as a common symptom, but it is demonstrated that higher impulsivity is a common underlying 
genetic vulnerability (Slutske et al., 2000), and is considered to be an endophenotypic indicator in both disorders (Bottesi et al., 2014; Salvatore et al., 2015). Endophenotypes can be defined as measurable components that are not visible explicitly along the pathways in between distal genotypes and the disease itself (MacKillop, 2013). Concerning addictive disorders, thus AUD and GD, impulsivity is not regarded as a unitary construct, consequently it is not likely to be traceable in studies as an endophenotype as a whole, but specific aspects like the ability to delay rewards as a form of cognitive impulsivity has been proposed as a cognitive endophenotype (Salvatore et al., 2015). Moreover, there is evidence that higher impulsivity may not only occur in the clinical presentation of GD, but may also be present in case of milder, subclinical problem gambling (Buja et al., 2017; Cunningham-Williams et al., 1998; Vitaro et al., 1999).

\subsection{Neural background of impulsivity}

The complex neurobiological underpinnings of impulsivity as a construct, and its behavioural and neurobiological relationship with AUD and GD are well documented in scientific literature (Mitchell \& Potenza, 2014; Perry \& Carroll, 2008). It has been documented concerning the neurobiological basis of impulsivity that the monoaminergic corticostriatal systems are massively impacted (Fineberg et al., 2014). Imaging studies of the human brain also reported structural and functional changes in the corticostriatal circuitry of impulsive individuals (Mackey et al., 2017). Dysregulation and/or disfunction of the monoaminergic signalling (particularly in the dopaminergic (DA) and serotoninergic (5HT) systems), concerning which, it has been stated that these form the basis of response impulsivity and choice impulsivity as well (Mitchell \& Potenza, 2014). The role of three neurobiological systems were highlighted in connection with impulsivity: 1) the ventral striatum and the midbrain dopaminergic system; 2) the regulatory system mediated by the medial and ventral prefrontal cortices and 3) the amygdala. From a neuropsychological perspective, impulsivity is regarded to arise from the impairment of inhibitory control, where the core components are the dysregulated activity of the network of cortical and subcortical structures including the lateral prefrontal cortex (Kozak et al., 2018).

Prolonged gambling activity and alcohol administration are known to result in neurotoxic effects, which cause neural loss in "top-down" control regions of the human brain: in the orbitofrontal cortex, prefrontal cortex, paraventricular and supraoptic nuclei of the cerebellum and the hypothalamus, superior frontal association cortex, which play crucial roles in affective processing, response inhibition and decision making as a form of impulsivity 
(Everitt \& Robbins, 2005; Fein, Bachman, Fisher, \& Davenport, 1990; Harding, Wong, Svoboda, Kril, \& Halliday, 1997). As it has been previously demonstrated, the failure of abstaining from an addictive behaviour even in case of facing adverse or negative consequences is a diagnostic feature both in GD and AUD (Alessy \& Petry, 2003; Bechara et al., 1994; Hodgins \& Holub, 2015). Such a failure in controlling one's actions indicates inadequate inhibitory control, in which patients are unable to suppress the undesired, maladaptive act of gambling or drinking behaviour. This impairment reflects on deteriorated inhibitory control and decision-making, which represent a form of impulsivity (Everitt \& Robins, 2005; Mitchell \& Potenza, 2014).

\subsection{Aspects of impulsivity and their assessment}

Despite having an agreement in the scientific literature regarding impulsivity as a complex, multifaceted construct, there is still no consensus on the exact classification of the subdimensions comprising the multifactorial nature of impulsivity (Evenden, 1999; Moeller et al., 2001). On this notion, current measurements of the different aspects of impulsivity range from self-assessment, measures and electrophysiological neurocognitive assessments of impulsiveness (de Wit, 2009; Moeller et al., 2001; Bornovalova et al., 2005). Self-report comprises of individuals' correct recollection of their own behaviour, while behavioural/electrophysiological analyses of impulsivity are considered to be more objective, since they often involve the recording of prepotent motor signals (Daugherty et al., 2005; Moeller et al., 2001). The available numerous assessment options can be enrolled under four main subdomains measuring distinct aspects of impulsivity. The most widely accepted measurement tools used in both clinical and research settings were selected for presentation in the present thesis. For a detailed, comprehensive summary of the assessment and description of these subdomains of impulsivity, see Table 3.

Table 3: List and brief description of assessment tools evaluating the different aspects of impulsivity

\begin{tabular}{|c|c|}
\hline Name of assessment tool & Description \\
\hline $\begin{array}{l}\text { Novelty Seeking subscale of the } \\
\text { Temperament and Character } \\
\text { Inventory (TCI) }{ }^{1}\end{array}$ & $\begin{array}{l}\text { A } 240 \text {-item personality test assessing seven aspects of personality, } \\
\text { from which the Novelty Seeking subscale is designed to measure } \\
\text { impulsiveness, impulsive decision making and people's response to } \\
\text { new stimuli }\end{array}$ \\
\hline $\begin{array}{l}\text { Eysenck Impulsiveness Scale } \\
\text { (EIS) }{ }^{1}\end{array}$ & $\begin{array}{l}\text { A 54-item yes/no questionnaire designed to measure } 3 \text { domains of } \\
\text { impulsiveness: impulsiveness, venturesomeness and empathy }\end{array}$ \\
\hline $\begin{array}{l}\text { Dickman Impulsivity Inventory } \\
{\text { (DII })^{1}}\end{array}$ & $\begin{array}{l}\text { A 23-item true or false questionnaire determining functional or } \\
\text { dysfunctional impulsivity }\end{array}$ \\
\hline
\end{tabular}


Urgency, Premeditation (lack of), Perseverance (lack of), Sensation Seeking, Positive Urgency, Impulsive Behavior Scale (UPPS-P) ${ }^{1}$

\section{Barratt Impulsivity Scale (BIS-} 11) ${ }^{1}$

\begin{tabular}{c}
\hline Multidimensional Personality \\
Questionnaire (MPQ) \\
\hline Impulsive/Premeditated \\
Aggression Scale (IPAS) $^{2}$ \\
\hline Aggressive Acts Questionnaire \\
(AAC) $^{2}$ \\
\hline Point Subtraction Aggression \\
Paradigm (PSAP) \\
\hline Buss-Perry Aggression \\
Questionnaire (BPAQ) \\
\hline
\end{tabular}

Experiential Discounting Task $(\mathrm{EDT})^{3}$

\begin{tabular}{c}
\hline $\begin{array}{c}\text { Kirby Delay Discounting Task } \\
(\text { KDDT })^{3}\end{array}$ \\
\hline $\begin{array}{c}\text { Temporal Choice Discounting } \\
\text { Task (TCDT) })^{3}\end{array}$ \\
\hline
\end{tabular}

Delay Discounting Task ${ }^{3}$

Stop Signal Task $(\mathrm{SST})^{4}$ speed and accuracy of responding

A 59-item self-assessment rating scale measuring the following dimensions of impulsivity: negative urgency, lack of premeditation, lack of perseverance and sensation seeking

A 30-item paper and pencil rating scale assessing 3 aspects of impulsivity: motor impulsivity, attentional impulsivity and nonplanning

A 276-item true or false personality test, in which impulsivity is a component of personality in a form of control vs. impulsivity

A 30-item self-report scale incorporating questions concerning impulsive aggression and premeditated aggression

A 22-item self-report scale assessing aggressive acts as being impulsive or premeditated

Computer-based test measuring impulsive aggression by behavioural response

29-item self-report questionnaire rating 4 subdomains of impulsive aggression (physical and verbal aggression, anger and hostility) on a 5-point Likert-type scale

Computerized task in which participants experience consequences of their choices: earning monetary rewards vs. evading monetary losses

A 27-item test comprising monetary choices between smaller immediate and larger delayed rewards

Computerized task measuring preference of immediate reward subjectivity

A 138-item computerized task evaluating temporary and delay discounting by deciding between two hypothetic amounts of reward offered in different time points
A computerized reaction time task measuring response inhibition by

A computerized neuropsychological task measuring cognitive

Go/No-Go type paradigms ${ }^{4}$ impulsivity by training individuals to give a particular response to "go" stimuli and no response to "stop" signals

A computerized neuropsychological task in which stimulus cards are to be classified under 4 decks of cards by rules previously unknown to the participant

A computerized neuropsychological task measuring impulsive

Rogers Decision-Making Task $(\text { RDMT })^{4}$

decision-making by choosing different colours of boxes, resulting in different monetary gains

Balloon Analogue Risk Task $(\text { BART })^{4}$

A computerized neuropsychological task assessing risk behaviour as a form of impulsive decision-making by inflating a balloon till a breakpoint unknown to the participant

A computerized neuropsychological task assessing participants preference or aversion towards risky decisions by rolling dice and betting outcomes by high probability/low layoff versus low probability/high payoff

A computerized neuropsychological task assessing impulsive

Probability-Associated

Gambling Task (PAGT) ${ }^{4}$ decision-making by deciding between choosing a fixed (smaller) gain or gamble for higher gain (but with high chance of monetary loss)

A computerized neuropsychological task with outcome measures of risk taking, decision time, risk adjustment, quality of decisionmaking, delay aversion and impulsivity 
A computerized neuropsychological task evaluating risk

Columbia Card Task (CCT) ${ }^{4}$ preferences, the use of information through choices made in a game of cards

\begin{tabular}{|c|c|}
\hline Cups Task $(\mathrm{CT})^{4}$ & $\begin{array}{l}\text { A computerized neuropsychological task assessing risk preferences } \\
\text { through } 54 \text { trials of a game in order to achieve monetary gain }\end{array}$ \\
\hline Iowa Gambling Task $(I G T)^{4}$ & $\begin{array}{l}\text { A computerized neuropsychological task in which during } 100 \text { trials } \\
\text { participants select from } 4 \text { decks of cards with different win/loss } \\
\text { ratios to gain as much money as they can }\end{array}$ \\
\hline $\begin{array}{l}\text { Numbers in upper index represen } \\
\text { aggression; }{ }^{3} \text { - choice impulsivity/c }\end{array}$ & $\begin{array}{l}\text { he domain of impulsivity measured: }{ }^{1}-\text { trait impulsivity; }{ }^{2} \text { - impulsive } \\
\text { ay discounting; }{ }^{4} \text { - impulsive decision making/risk preference; Assessment }\end{array}$ \\
\hline
\end{tabular}

\subsubsection{Impulsivity as a component of personality}

The classical trait concept of impulsivity can be defined as a component of personality, which involves a tendency towards displaying such behaviour that is characterized by little or even no reflection, forethought or consideration of consequences. It has traditionally been characterized as an enduring and stable personality trait, which can be measured by a range of self-reported assessment scales. These tools include the relevant subscales (i.e. Novelty Seeking and Harm Avoidance) of Cloninger's Temperament and Character Inventory (Cloninger, Svrakic, \& Przybeck, 1991), Eysenck Impulsiveness Scale (Eysenck \& Eysenck, 1977), Dickman Impulsivity Inventory (Dickman, 1990), the UPPS-P Impulsive Behavior Scale (Whiteside \& Lynam, 2001) and one of the most widely accepted and clinically used measurement tool, the Barratt Impulsivity Scale (Patton et al., 1995). Despite some overlaps, the precise feature measured in these tests are somewhat different. More specifically, the Eysenck Impulsiveness Scale yields a single impulsivity score comprising of risk-taking, non-planning and liveliness subscales. The Dickman Impulsivity Inventory differentiates between dysfunctional and functional impulsivity, which represents adaptive/optimal and maladaptive/problem-causing forms of impulsiveness. The UPPS Impulsive Behavior Scale employs four subdimensions: premediation, urgency, sensation seeking and perseverance; the Temperament and Character Inventory is a complex assessment of personality factors, from which certain aspects are related to impulsiveness. While the Barratt Impulsivity Scale is designed to assess attentional, motor and non-planning subdimensions of trait impulsivity (Patton et al., 1995).

Another dimension of impulsiveness is impulsive (unplanned) aggression, which can be defined as an unpredictable or sudden use of force or action without taking into consideration of the consequences of this behaviour. From a physiological aspect, impulsive aggression is hypothesized as a partially biologically-based construct, where cortical 
inhibitory mechanisms and the results of the interactions of serotonin, the prefrontal cortex, the amygdala and the limbic system play essential roles in the emergence of aggressive impulses (Blair, 2016; Kavoussi et al., 1997). Several measures are in use to indicate impulsive aggression including in-vivo evaluation of the actual behaviour. The Impulsive/Premediated Aggression Scale (Stanford, Houston \& Mathias, 2003), the Aggression Acts Questionnaire (Barratt et al., 1999) or the Point Subtraction Aggression Paradigm (Cherek, 1981) separate aggression into two domains, premediated and impulsive aggression, while the Buss-Perry Aggression Questionnaire (Buss \& Perry, 1992), which is one of the most frequently used assessment tool in this field distinguishes four subdomains of aggression in the evaluation of impulsive aggression.

\subsubsection{Neurocognitive approach of impulsivity}

Impulsivity has also been studied in connection with cognitive processes, where several perspectives has been addressed with distinct neurocognitive assessment approaches designed to obtain a more objective measure of impulsivity. An empirically investigated component is choice impulsivity, which can be defined as making haste choices and having tendencies of preferring smaller but instant gratifications over later but larger rewards. That aspect is directly connected to the inability to exert self-control or delay gratifications, which are important elements of addictive behaviour (Fineberg et al., 2010). Neuropsychological assessments of this aspect of impulsivity include delay discounting and temporal discounting (Matta, Gonçalves \& Bizarro, 2012), from which some measurements focus on the decrease of the monetary or subjective value of the reward when it is delayed (Tesch \& Sanfey, 2008), such tests are the Experiential Discounting Task (Reynolds \& Schiffbauer, 2004), while others prioritize on the timely tendency of preferring a certain amount of reward in a shorter or longer time frame, i.e. choosing a reward or consequence with lower value as long as it is released immediately or in shorter time (Mitchell, 1999). Temporal discounting tasks are the Kirby Delay Discounting Task (Kirby \& Maraković, 1996), the Temporal Choice Discounting Task (Rachlin, Raineri \& Cross, 1991). The most widely used paradigm for assessing choice impulsivity is the Delay Discounting Task paradigm (Mitchell, 1999), in which delay of the monetary reward and the factor of time are combined.

Decision-making as a form of cognitive impulsivity is widely evaluated in the scope of addictive disorders. Bechara (2005) defined decision-making as a complex cognitive process allowing individuals to choose the most optimal course of action, which is preceded by reasoned consideration of possible existing alternatives. In case of addictive disorders, the 
assessment of decision-making dominantly focuses on neurocognitive performance tasks assessing inhibitory control. Several paradigms are of use, albeit reflecting on distinct aspects of cognitive impulsivity. The Stop Signal paradigm (Logan, 1994) assesses the inhibition of a prepotent motor response, while the Go/No-Go type paradigms (Newman et al., 1990) evaluate the ability of the learning to inhibit responses with punishments, thus measuring passive avoidance. Another form of measuring cognitive flexibility as a form of impulsive decision-making is the Wisconsin Card Sorting Task (Berg, 1948; Piper et al., 2015), which reflects on executive functions, such as learning, attention control, flexibility in response selection and adaptation to shifts in task contingencies. Therefore, it can be associated with the cognitive dimension of impulsivity, and with poor decision-making. Also, other measures of impulsive decision-making are the Rogers Decision-Making Task (Rogers et al., 1999) exhibiting boxes covering monetary gains or losses, and the Balloon Analogue Risk Task (Lejuez et al., 2002) simulating real-life risk behaviour by having to inflate a balloon with each inflation resulting in monetary gain, with the breakpoint of the balloon remaining unknown to the participants.

Most of the tasks measuring impulsive decision-making centre around gambling paradigms. These include several different form of games, like the Game of Dice Task (Brand, Fujiwara, et al., 2005) uses dice, the Probability-Associated Gambling Task (Sinz et al., 2008; Zamarian et al., 2008) includes lotteries, the Cambridge Gambling Task (Rogers et al., 1999) and the Columbia Card Task (Figner, Mackinlay, Wilkening \& Weber, 2009) incorporate cards, while the Cups Task (Levin \& Hart, 2003) utilizes cups. The aim of these tests is similar: to result in a more favourable win/loss ratio, i.e. being capable of utilizing a strategy that results in more monetary gain. Similar to this purpose, the Iowa Gambling Task (Bechara et al., 1994; Bechara et al., 1997), also uses cards as a means of measurement, while this tool is considered to be one of the most widely accepted and utilized methods of assessing this aspect of impulsiveness.

In the present thesis, concerning the classification of the distinct features of impulsivity and the relationship of more specific aspects and measurement approaches of this construct, four widely accepted, empirically examined dimensions of impulsivity were assessed, utilizing both self-assessment and computerized neuropsychological measurements: i) the traditional trait concept of impulsivity, as a maladaptive behaviour without any attention to evade potential harm (Patton, Stanford \& Barratt, 1995; Whiteside \& Lynam, 2001); ii) choice impulsivity as the inability to delay instant gratifications (Grant \& Chamberlain, 2014; Peters \& Büchel, 2011; Mitchell, 1999); iii) impulsive aggression (Blair, 2016; Buss \& Perry, 
1992; Kavoussi, Armstead \& Coccaro, 1997) and iv) deficits of response inhibition and impulsive decision making (Bechara et al., 1997; Franken et al., 2008) Assessment tools covering these four domains of impulsivity incorporated in the present thesis are presented in bold italics in Table 3 .

\section{Importance of impulsivity in alcohol use and gambling disorder}

Impulsivity has been proven to be not just a predictor of severe alcohol consumption and gambling activity in later life (Dussault et al., 2011; Hentges et al., 2018; Jacob, Haro \& Koyanagi, 2018), but there is evidence that the acute intake of alcohol and the engagement in gambling activity also induce impulsiveness in humans (Hodgins \& Holub, 2015; McCarthy et al., 2012). This is directly linked to impulsive actions evolving into compulsive behaviour, i.e. impulsivity leading to compulsion, which is strongly connected to the development of severe forms of GD and AUD (Berlin \& Hollander, 2008). Impulsivity in case of both AUD and GD has been linked to negative accompanying features like the increase in addictive symptom severity, thus more alcohol intake and higher gambling activity (Aragay et al., 2018; Stevens et al., 2017), poor clinical outcomes (Charney, Zikos \& Gill, 2010; Moeller et al., 2001 ) or the increase of relapse risk (Evren et al., 2012; Goudriaan et al., 2005). Greater impulsivity is associated with greater addictive symptom severity both in the case of GD and AUD. Higher impulsivity in these patient groups is also associated with antisocial personality, more maladaptive coping mechanisms, disinhibition and higher sensation seeking (Blaszczynski, Steel, \& McConaghy, 1997; Steel \& Blaszczynski, 1998; Vitaro, Arseneault, \&Tremblay, 1999; Vitaro, Ferland, Jacques, \& Ladouceur, 1998), which are features prone to increase the risk of relapse.

GD and AUD patients with higher levels of impulsivity may be at even higher risk of relapse, since they tend to make decisions without adequately thinking over or weighing all the possible options and outcomes. It was also indicated that higher impulsiveness was related to treatment failure in case of both. One possible reason for that was that impulsivity made it difficult for patients to benefit from treatment, since the actual rewards of the treatment are long-term ones, while the gain from pursuing alcohol/gambling activity is more immediate disorders (Leblond, Ladouceur, \& Blaszczynski, 2003; Rubio, Martínez-Gras \& Manzanares, 2009).

Extensive literature exists on the assessment of impulsivity solely in AUD or in GD, but only few studies have addressed both patient groups in the same setting. Petry (2001) examined the characteristics of impulsivity in substance-abusing GD patients, substance 
abusers without GD and healthy controls, where substance abusing GD patients showed the highest levels of impulsivity from all groups. Lawrence et al. (2009) contrasted the differences of 21 GD patients who did not seek treatment, 21 AUD outpatients and healthy controls in terms of two neuropsychological tests of cognitive impulsivity. Deficits were found in tasks loading on the ventral prefrontal cortex in both patient groups, while tasks loading on the dorsolateral prefrontal cortex showed impairment only in the AUD patient group, presumed to be a consequence of long-term alcohol intake. Goudriaan et al. (2005) compared 46 AUD and 48 GD outpatients' performance on three different decision-making tasks and highlighted that AUD patients' performance was marginally worse than the performance of the GD group. Bottesi et al. (2015) contrasted the results of 44 GD and 75 AUD (inpatients and outpatients mixed in the sample) on cognitive and self-reported impulsivity tasks and showed similar patterns of impulsivity in both patient groups.

\section{AIMS AND HYPOTHESES}

It has been well documented that AUD and GD show similarities in symptomatology, aetiology, epidemiology and comorbidity with other psychiatric disorders. From these, higher impulsivity is of key importance, since it has not only been proved to be a comorbid symptom, but has been established to characterize both disorders as a common vulnerability marker, with one aspect of impulsivity, cognitive impulsivity serving as a potential cognitive endophenotype in AUD and GD. Based on these and the theoretical background detailed above, the present thesis centres around two empirical studies with the following aims:

Aim 1: Scientific literature points out that AUD and GD are both characterized by higher levels of impulsivity, although in terms of the different aspects of impulsivity, exact findings are inconclusive (Lawrence et al., 2009; Petry, 2001); one aspect, cognitive impulsivity is proposed as a potential endophenotype in both disorders (Salvatore et al., 2015). Based on this, in the first part of the thesis (in Study I), this facet of impulsivity, impulsive decision-making, i.e. cognitive impulsivity was chosen to be examined closely in the framework of a systematic review-based quantitative meta-analysis. For this purpose, one assessment tool was selected to measure the dimension of impulsive decision-making: the Iowa Gambling Task (Bechara et al., 1994; Bechara et al., 1997), which is considered to be the most commonly used and ecologically valid computerized neuropsychological task for measuring real-life impulsive decision-making in laboratory circumstances. On this notion, the following main hypotheses were formed: 
$\mathrm{H}_{1}$ : Both AUD and GD patient groups showed impaired decision-making measured with the IGT compared to matched HC group.

$\mathrm{H}_{2}$ : AUD and GD patient groups can be differentiated in terms of decision-making measured by the IGT net scores.

Aim 2: Higher impulsivity both in AUD and in GD has been associated with negative concomitant features like higher addiction-related symptom severity, i.e. more severe alcohol consumption (Aragay et al., 2018) and more intensive gambling activity (Stevens et al., 2017), elevated risk of relapse (Evren et al., 2012; Goudriaan et al., 2005). However, despite the high documented comorbidity (Feigelman et al., 1998; Manning et al., 2017; Stinchfield et al., 2005), these studies were only conducted in cases of sole diagnoses of either AUD or GD. Based on these, in the second part of the present thesis (in Study II), the occurrence of concomitant GD symptoms in a chronic, long-term AUD patients were evaluated, with a more comprehensive assessment of impulsivity in patients with and without comorbid GD symptom. In Study II, the multifaceted nature of impulsivity was also taken into consideration, a complex set of test battery was utilized covering four different aspects of impulsivity: trait, choice and cognitive impulsivity and impulsive aggression. On this notion, the following hypotheses were formed:

$\mathrm{H}_{3}$ : The prevalence of comorbid GD symptoms with AUD fits in with international trends in inpatient treatment unit for AUD.

$\mathrm{H}_{4}$ : Long-term AUD patients with comorbid GD symptoms express higher symptom severity of substance use and psychopathological symptoms.

$\mathrm{H}_{5}$ : Long-term AUD patients with comorbid GD symptoms present higher levels of trait impulsivity, choice impulsivity, impulsive aggression and impulsive decision-making. 


\section{METHODS AND MATERIALS}

\section{STUDY I}

In Study I, a single domain of impulsivity, namely cognitive impulsivity in the form of impulsive decision-making was selected for comparison between patients with DSM or ICD diagnoses of either AUD or GD and matched healthy controls. From the potential measurements of cognitive impulsivity (see Table 3 above), the Iowa Gambling Task (IGT) (Bechara et al., 1994; Bechara et al., 1997) was selected for incorporation, since this computerized neuropsychological task is one of the most frequently used and ecologically valid assessment tools for evaluating real-life decision-making in laboratory environment.

\subsection{Search strategy and study selection}

This systematic review and meta-analysis are reported in accordance with the Preferred Reporting Items for Systematic Reviews and Meta-Analyses (PRISMA) statement (Moher et al., 2009) and the quantitative meta-analysis conforms to the guidelines of metaanalyses in epidemiology described by Stroup et al. (2000). In March 2016, three scientific databases (Medline/Pubmed, ScienceDirect and Web of Science) were thoroughly searched to determine empirical studies concerning alcohol use disorder and gambling disorder and the Iowa Gambling Task (IGT). The following search terms were applied: ("alcohol dependence" OR "alcohol use disorder" OR "pathological gambling” OR "gambling use disorder") AND ("Iowa Gambling Task" OR "decision making”) with the following filtering: "Title/Abstract", "Title, Abstract, Keywords" and "Topic" respectively for the above mentioned search engines. Our systematic literature search identified a total of 1,198 findings for potential inclusion in the meta-analysis. Several non-peer-reviewed results were found as a result of the literature search. After examination with every author, all grey literature (e.g. unpublished dissertations, abstracts of conference presentations or posters) $(N=46)$ was excluded. After the removal of these results, articles were hand-screened for eligibility. Papers that lacked a DSM or ICD diagnosis of either GD or AUD, did not use the IGT for measuring decision making as an aspect of cognitive impulsivity $(N=846)$, used primate or rodent models $(N=$ $50)$, or were not published in English $(N=31)$ were excluded from the quantitative analysis. Papers were included in case they were based on empirical data resulting from clinically diagnosed populations (i.e. DSM or ICD diagnosed patients) and assessed the net score of IGT performance as an evaluation of cognitive impulsivity. After the appliance of every exclusion criteria mentioned above and removing duplicates, 17 studies remained and met the previously set inclusion criteria for qualitative meta-analysis (see Figure 1). 


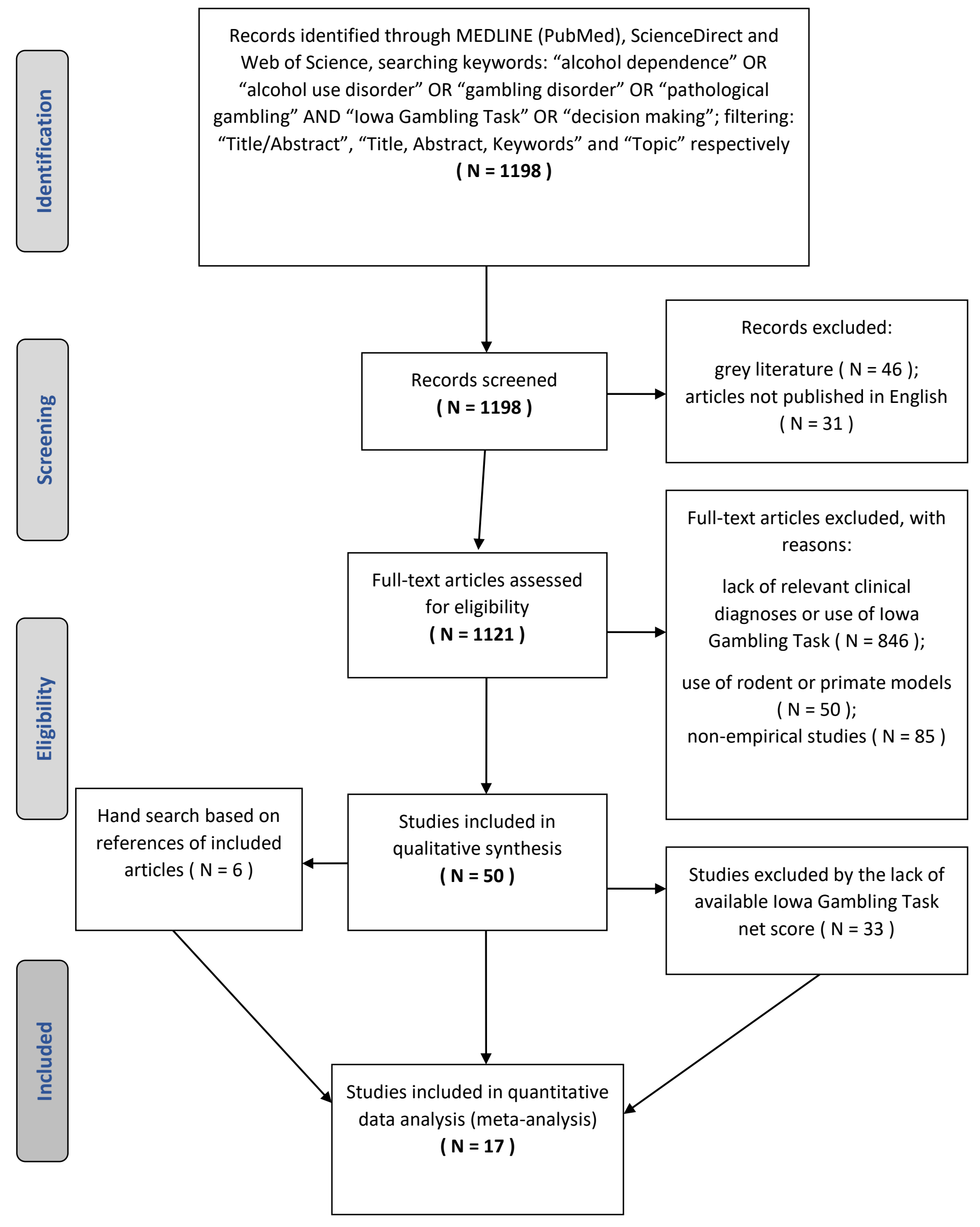

Figure 1: PRISMA flow diagram 


\subsection{Raw data extraction for quantitative meta-analysis}

Upon encountering a possibly eligible article that lacked the report of sufficient raw data of the AUD or GD patients' IGT net scores compared to HCs to permit the inclusion in the meta-analysis, corresponding authors of the 33 studies without sufficient data were contacted via e-mail up to three times over a month to ask for the missing pieces of data. Consequently, Forbush et al. (2008), Zorlu et al. (2013) and Zorlu et al. (2014) made their initial database available from where the required data could be extracted, resulting in a final study number of 17 that were incorporated into the quantitative meta-analysis, from which 23 contrasts were obtained from AUD/GD groups compared to HCs, which was the unit of data analysis.

\subsection{Statistical analysis}

Since heterogeneity was anticipated, every analysis was conducted with the use of random-effects model, including the estimation of publication bias, calculations of effect sizes, subgroup analysis and moderator analyses. Meta-regression was conducted to examine potential mediators like the proportion of males, mean years of education and age. The issue of assessing other potential demographic and/or clinical moderator variables were raised; however, most of the studies lacked the inclusion of data regarding such potential moderators (i.e. length of abstinence) that could have been used as moderator variables. All analyses were calculated using the Comprehensive Meta-Analysis (CMA) 3.0 software (Comprehensive Meta-Analysis Software, 2017).

Several studies yielded more than one units of analyses, for which the method of data handling was the following: Dom et al. (2006) contrasted decision making of HCs and AUD patients with or without personality disorders, which yielded 3 contrasts (3 patient groups matched with HCs) for the present meta-analysis. Cordovil et al. (2010) assessed data in 2 time points: T1 represented the start of withdrawal and T2 the end of withdrawal. These two time points were divided and matched with the values of the $\mathrm{HC}$ group, resulting in two contrasts for meta-analysis. Kim et al. (2006) evaluated AUD patients and HCs with and without conduct disorder. In the present meta-analysis, only data from patients and HCs without conduct disorder was incorporated. Miranda et al. (2009) evaluated two AUD patient groups (with or without antisocial personality disorder) with a HC group, from which the two patient groups were matched with the HC group, resulting in two contrasts. Thus, the 
previously identified 17 studies yielded 23 contrast samples for the present aggregated analysis.

The presence of publication bias was assessed by conforming to the guidelines described by Sterne et al. (2011). An asymmetric visual/graphic examination of a funnel-plot was conducted, and mathematical methods for evaluating the possibility of publication bias as recommended by Begg and Mazumdar (1994) and Egger et al. (1997) were applied. In Egger's test, in case the $p$ value belonging to the linear regression intercept is 0.1 or below, it indicates statistically significant asymmetry. The influence and presence of outliers was evaluated by the examination of standardised residual for every study. A study was considered an outlier, in case its standardized residual was greater than \pm 3.29 (Shiffler 1988). The reason for calculating the effect of heterogeneity was to ascertain whether the results of the studies are consistent. In our meta-analysis, Q-test for heterogeneity was calculated within the two subgroups (Wiley 2017). The Q-test for heterogeneity is based on an approximate $\chi^{2}$ distribution and indicates the degree of deviation from homogeneity. A significant Q-value ( $p$ $<0.05)$ indicates statistically significant heterogeneity in the studies. To determine whether AUD and GD group results differ, the two groups' sampling variances ( $v_{l}$, for the AUD group and $v_{2}$ for the GD group) were calculated with the following formula, where $d$ signifies the observed Cohen's $d$ value:

$$
v=\frac{1}{\mathrm{n}_{1}}+\frac{1}{\mathrm{n}_{2}}+\frac{d^{2}}{2\left(n_{1}+n_{2}\right)}
$$

With this calculation made, the two treatment groups could be compared with the standard normal test statistics developed by Keef and Roberts (2004) with the formula below:

$$
z=\frac{\mathrm{d}_{1}-\mathrm{d}_{2}}{\sqrt{v_{1}-v_{2}}}
$$

where $|z| \geq 1.96$ indicates that the group difference is statistically significant. Moderator and covariate analysis were conducted to evaluate the connections between the differences of patient groups and HCs regarding the proportion of males, age, level of education and the age of the treatment groups. Moderators were considered significant in cases of categorical

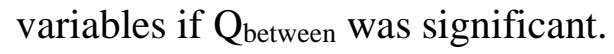

\section{STUDY II}

Since empirical research examining the different facets of impulsivity in AUD comorbid with GD could not be identified, the focus of Study II was to assess the comorbidity of the two disorders with addressing impulsivity from a broader perspective. For this purpose, 
the co-occurrence of comorbid GD symptoms was assessed in patients receiving inpatient treatment for AUD with a test battery assessing the severity of both addictions, psychopathological symptom severity and incorporating both objective and subjective measurements of the different aspects of impulsivity. For this, five tasks were selected, covering four domains of impulsivity: trait impulsivity, impulsive aggression, choice impulsivity and impulsive decision-making.

\subsection{Participants}

A comprehensive research project was carried out at the Department of Psychiatry, Faculty of Medicine, University of Szeged, Hungary. Inpatients treated with chronic AUD were measured for addiction characteristics, personality traits, executive functions, psychopathological symptom severity and comorbid psychiatric conditions. This section of the study mentioned above focused on the evaluation of objective and subjective measures of impulsivity, in which a total of 104 patients were enrolled. Patients were considered to be eligible in case they had an established DSM-5 diagnosis of AUD, finished at least primary education and had a level of intelligence above the level of intellectual disability (Fourth Edition of the Weschler Adult Intelligence Scale above 70). Patients with the history of progressive neurodegenerative disorders, any psychosis spectrum disorder, diseases affecting their sight, neurological diseases or who reported acute alcohol abuse were excluded. Due to voluntary termination of inpatient treatment, one patient was excluded from this study; thus, the final sample size was 103. Patients were classified into two groups based on the presence of comorbid GD symptoms (see Figure 2 for detailed patient inclusion flowchart).

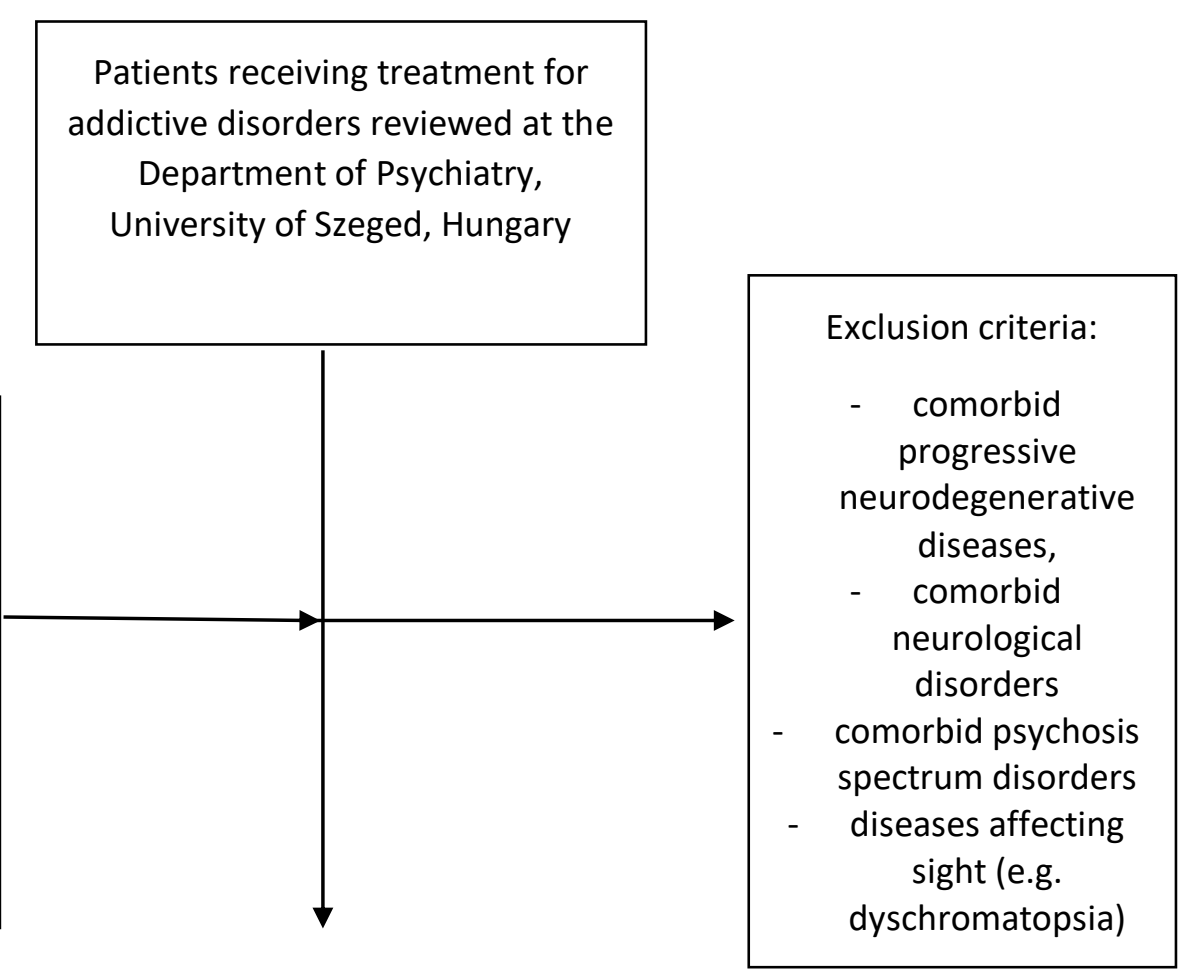




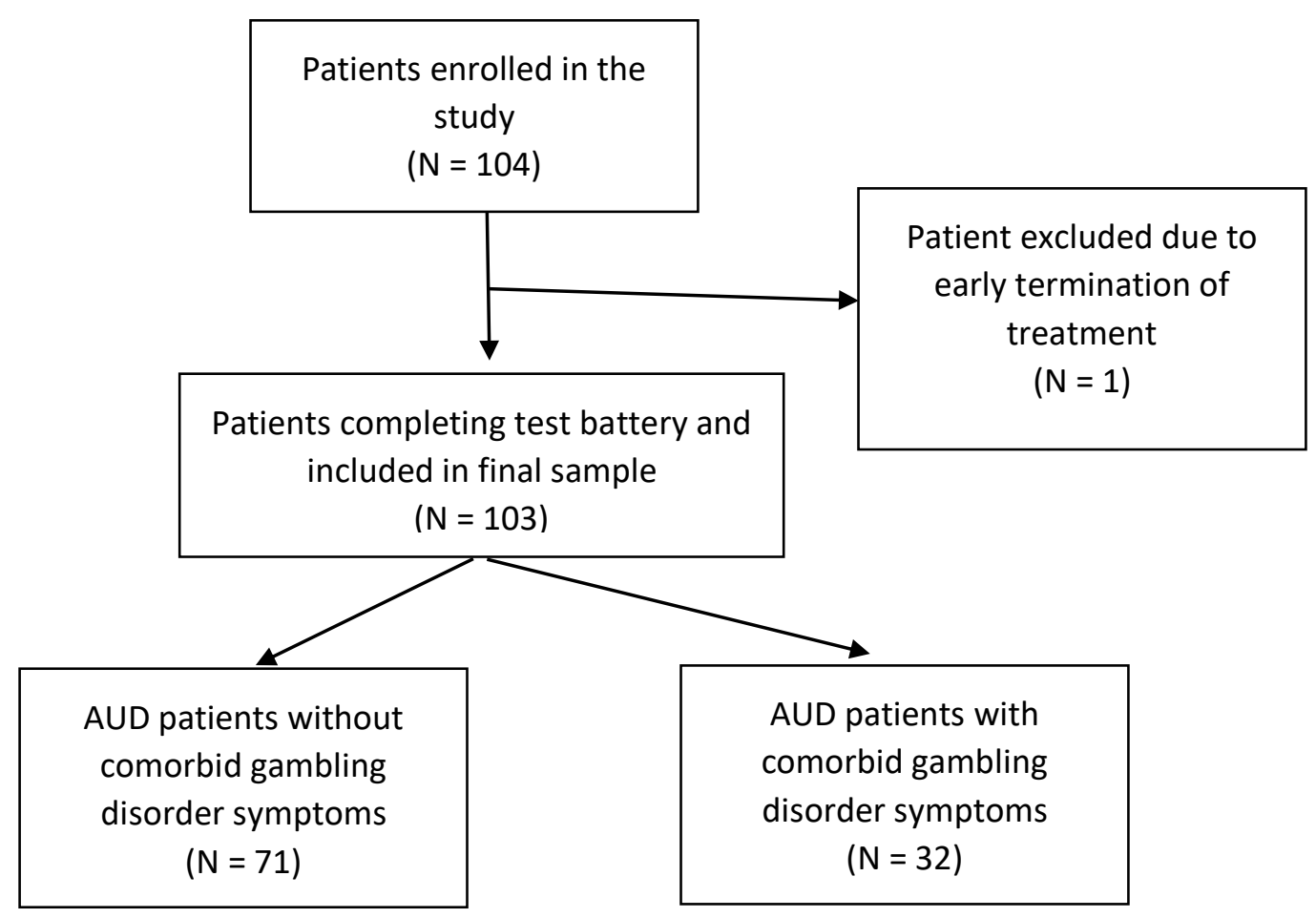

Figure 2: PRISMA flowchart of selection procedure

DSM: The Diagnostic and Statistical Manual of Mental Disorders, Fifth Edition; AUD: alcohol use disorder; WAIS-IV: The Wechsler Adult Intelligence Scale, Fourth Edition

The study was conducted in accordance with the Declaration of Helsinki and was approved by the Human Investigation Review Board, University of Szeged (ethical approval number: 49/B-53/2016KK). Written informed consents were obtained from every patient.

\subsection{Experimental paradigm}

\section{Barratt Impulsivity Scale (BIS)}

The BIS-11 (Patton, Stanford \& Barratt, 1995) is a self-evaluation questionnaire containing 30 items measuring three aspects of impulsivity: motor impulsivity, attentional impulsivity and non-planning. Each item is measured on a scale of 0 to 3 , where higher scores indicate higher levels of impulsivity. The Hungarian version adapted by Paksi et al. (2017) and showed good reliability in our sample: Cronbach's $\alpha=0.805$. 


\section{Buss-Perry Aggression Questionnaire (BPAQ)}

The BPAQ is a self-rated test for measuring 4 dimensions of aggressive impulses, which are the following: physical and verbal aggression, hostility and anger (Buss \& Perry, 1995). The Hungarian version was developed by Gerevich, Bácskai \& Czobor (2007) and showed good internal consistency and reliability in our sample: Cronbach's $\alpha=0.879$.

\section{Delay Discounting Task (DDT)}

In the DDT, as a measure of choice impulsivity, participants are asked to make a series of monetary choices where they have to choose between two different amounts of money that they hypothetically receive in distinct time intervals. Once presented, the rewards vary between 0HUF and 55,000HUF in 2,500HUF increments. The two choices may differ in the amount of money presented, and also receival are presented in a delay $(0,1,14,60,180$ or 365 days). One of the receival time of the two amounts signifying a closer time interval (e.g. "now") and the other presenting a later one (e.g. "in 2 weeks"). The DDT consists of 138 hypothetical questions presented in random order (i.e., Which of the two choices would you select? 12,500 HUF now or 50,000HUF two weeks later?). Patients select their choices with a single click on their preferred answers, then they continue the task by selecting the 'Next question' option. The aim of the task is to determine the point at which the immediate reward is preferred over the delayed reward. This is called as the 'indifference point', and it can be calculated for each period of delay. Above this indifference point, participants choose the immediate available selection (which is given in HUF), while below the indifference point, they select the option with delay (Mitchell, 1999).

\section{Iowa Gambling Task (IGT)}

The Iowa Gambling Task is considered to be one of the most frequently utilized and ecologically valid evaluation tools for measuring decision-making as an aspect of cognitive impulsivity. In this task, participants are asked to select 100 times from four decks of cards with different win/loss ratio, with the aim of winning as much money as they can. To do so, participants need to prefer decks, which result in lower immediate rewards and lower longterm losses as well, and yield higher long-term advantages, instead of selecting decks with higher immediate rewards accompanied with higher monetary losses (Bechara et al., 1994; Bechara et al., 1997). Units of data analysis were the following: the 100 choices were separated into blocks of 20 selections in each (five blocks). The amount of money won, and 
the total net score calculated by subtracting the number of advantageous selections from disadvantageous choices were also compared.

\section{Wisconsin Card Sorting Task (WCST)}

The WCST measures executive functions, cognitive flexibility and decision-making (Grant \& Berg, 1948). In this neuropsychological test, participants are asked to sort cards according to various rules with the only feedback of their selection being incorrect or correct. Four sample cards are given differing in pattern, colour and number of patterns. Participants need to match newly appearing cards under these sample cards. Cards can be classified according to their colour, their patterns or the number of patterns on each card. In every ten cards, the classification rule changes, which indicates that after the participant has figured out the classification rule, eventually the rule changes and they start making mistakes, and consequently they have to conform to the changing rules. In this study, the PEBL's computerised version of card sorting task was utilized (Berg, 1948; Piper et al., 2015). Units of data analysis were the following: the number of correct responses, the number of incorrect responses and the number of perseverative errors.

\section{Wechsler Adult Intelligence Scale (WAIS-IV)}

The WAIS-IV is the most widely used performance task to measure intelligence and cognitive ability. It comprises of 10 subtests with 5 supplementary tests, which measure four major components of intellectual capacities: Verbal Comprehension Index (VCI), Perceptual Reasoning Index (PRI), Working Memory Index (WMI) and Processing Speed Index (PSI) (Weschler, 2008). The Hungarian adaptation and standardization were conducted by Rózsa \& Kö (2008). The WAIS-IV total score was calculated, which is the cumulated scores of the VCI, PRI, WMI and PSI.

\section{Addiction Severity Index (ASI)}

The ASI covers 7 potential problematic areas (Alcohol, Drug, Medical, Employment/Support, Family/Social Status, Legal and Psychiatric) in a semi-structured interview concerning recent and lifetime substance-related problems (Butler et al., 2001). The Hungarian version was adapted by Rácz, Pogány \& Máthé-Árvay (2002). From the interview, the following variables were utilized: lifetime alcohol consumption in years, start of alcohol misuse in years and abstinence during the last 30 days. 


\section{South Oaks Gambling Screen (SOGS)}

The SOGS is a questionnaire consisting of 20 items based on the DSM-III criteria of pathological gambling (Lesieur \& Blume, 1987). The Hungarian adaptation was made by Gyollai et al. (2011) and showed good internal consistency. Scores between 1 and 4 indicate possible problematic gambling, while 5 or more points show probable pathological gambling.

\section{Alcohol Use Disorders Identification Test (AUDIT)}

The AUDIT developed by the World Health Organization is self-evaluation screening test comprising of 10 items, which assesses the severity of alcohol use and its adverse consequences (Saunders et al., 1993). The Hungarian version by Gerevich, Bácskai \& Rózsa (2006) showed good validity and reliability in our sample: Cronbach's $\alpha=0.763$.

\section{Symptom Checklist-90-R (SCL-90-R)}

The SCL-90-R is a self-report questionnaire containing 90 items for measuring a wide range of currently prevailing psychopathological symptoms (Derogatis, 1986). Items are rated from 0 to 4 on a scale where the more points stand for the presence of more severe psychopathological symptoms during the past week. The test assesses nine symptom dimensions with three global indices, from which the Global Severity Index (GSI) can be used as an indicator of psychopathological symptoms severity. The Hungarian adaptation showed excellent internal consistency and reliability in our sample: Cronbach's $\alpha=0.953$ (Urbán et al., 2016; Urbán et al., 2017).

\subsection{Statistical analysis}

Data analysis was conducted with IBM SPSS Statistics 24.0 software (IBM Corp, 2016). Based on the scores of the SOGS, the clinical sample was divided into two groups: 1) patients who scored 0 on the SOGS were classified as AUD patients without gambling symptoms (AUD group) and 2) patients who scored 1 or above were categorized as AUD patients with probable or problem gambling symptoms (AUD+Gambling group). The DDT indifference point value was computed in Microsoft Excel 2016 with a hyperbolic equation fitted for each participant's indifference point (Mazur, 1987; Mitchell, 1999) with the use of the Solver subroutine:

$$
V=\frac{S t d}{1+k X}
$$


where $V$ signifies the value of the indifference point, Std is the amount of money available (55,000HUF), $k$ stands for a fitted parameter, which indexes the rate of discounting, and $X$ indicates the length of delay. The steepness of the curve $(k)$ is fitted to the subjective value of each point of delay. When the curve is steeper (which means that the $k$ value is closer to zero), the patient prefers immediate over delayed rewards, which signifies more impulsive choices.

Independent-samples $t$-tests were utilized to determine group differences for continuous variables and Chi-square tests were used to compare demographic parameters of categorical variables. Partial correlation analysis was calculated to reveal the relationship between the different facets of impulsivity and gambling symptom severity. The effect of demographic variables, psychopathological symptoms and measures of impulsivity on the likelihood that patients have problem gambling symptoms was examined with binary logistic regressions with forward stepwise regression method.

Effect sizes were calculated using Cohen's $d$ (Rosnow, Rosenthal \& Rubin, 2000), as the standardized difference between two means to measure the experimenter effect. Cohen (1988) categorized effect sizes of $0.2-0.3$ as a "small" effect size, 0.5 as a "medium" effect and above 0.8 as a "large" effect size. 


\section{RESULTS}

\section{STUDY I}

\subsection{Analysis of aggregated raw data}

The 17 studies and the 23 contrasts are detailed in Annex 1. Overall, a total of 792 AUD or GD patients were compared to $568 \mathrm{HCs}$. The random effects estimate indicated impaired IGT performance in both AUD patients $(N=500 ; d=-0.581$, CI: $-89.5<\delta<-$ $26.6 \%)$ and GD patients $(N=292 ; d=-1.034, \mathrm{CI}:-156.1<\delta<50.7 \%)$. It is also evident, that AUD patients display less advantageous decision making than controls and the same is true for GD patients (Figure 3). In order to compare the two groups' results, sampling variances were calculated for both AUD $\left(v_{1}=0.0056\right)$ and GD groups $\left(v_{2}=0.0061\right)$, from which zscore was calculated $(\mathrm{z}=-21.0785)$. This indicates statistically significant difference between AUD and GD groups, meaning that the overall deficit is more expressed in GD as compared to AUD.

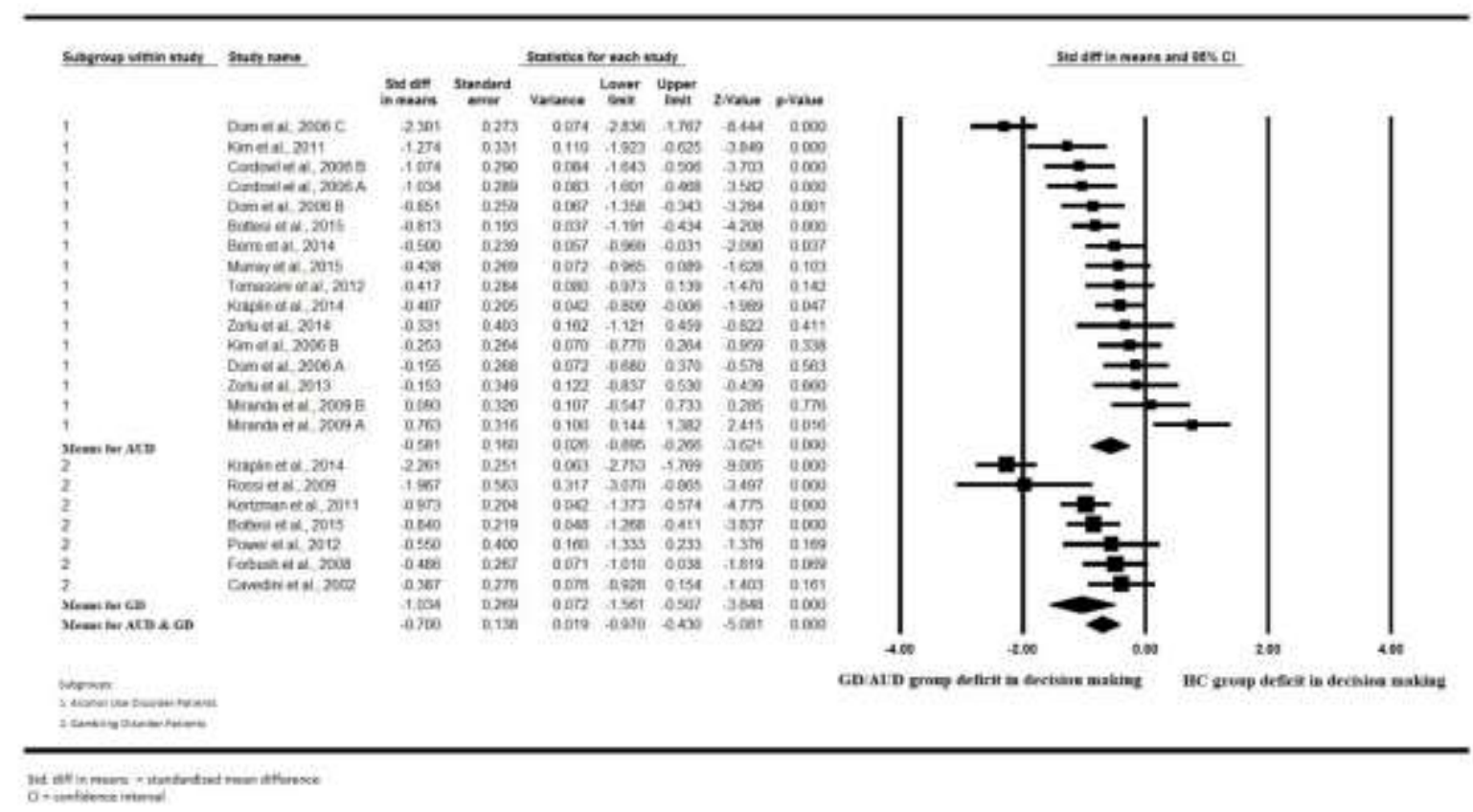

Figure 3: Forest plot of standardized difference in means for the two subgroups

\subsection{Publication bias and heterogeneity}

The funnel plot depicting standard errors appears to be symmetric for both AUD (Figure 4) and GD (Figure 5), Egger's test for intercept indicated symmetry (intercept $=0.796, P$-value $=0.745)$. Similarly, the Begg and Mazumdar test could not detect evidence of publication bias (Kendall's tau $=0.05929, p=0.672$ ) either. 
It was estimated that there was a high likelihood of contextual and methodological heterogeneity because of the differing health service contexts regarding each study; therefore, a random effects model was utilized to calculate the summary effect estimates. There was significant heterogeneity in the sample $\left(\mathrm{Q}_{\mathrm{w}}=131.217, d f=22, p<0.001\right)$ but the two subgroups (AUD: $\mathrm{Q}_{\mathrm{w}}=81.72, d f=15, p<0.001, \mathrm{GD}: \mathrm{Q}_{\mathrm{w}}=30.62, d f=6, p<0.001$ ) did not differ from each other in terms of heterogeneity $\left(\mathrm{Q}_{\mathrm{w}}=2.097, d f=1, p=0.149\right)$. Significant heterogeneity was detected, thus we conducted moderator and covariate analyses on the sample.

\section{Funnel Plot of Standard Error by Std diff in means}

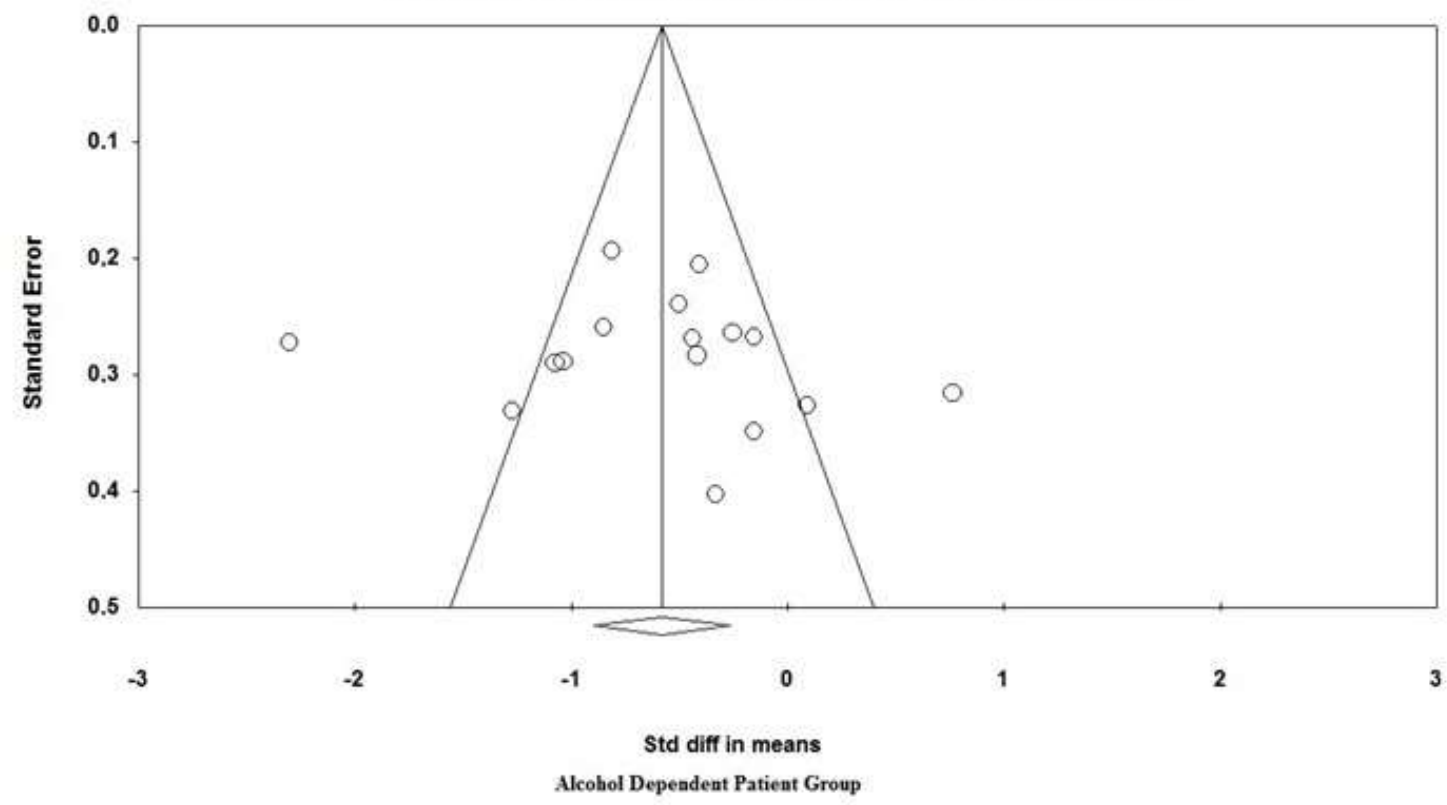

Figure 4: Funnel Plot of Standard Error by standardized mean differences in AUD group

Funnel Plot of Standard Error by Std diff in means

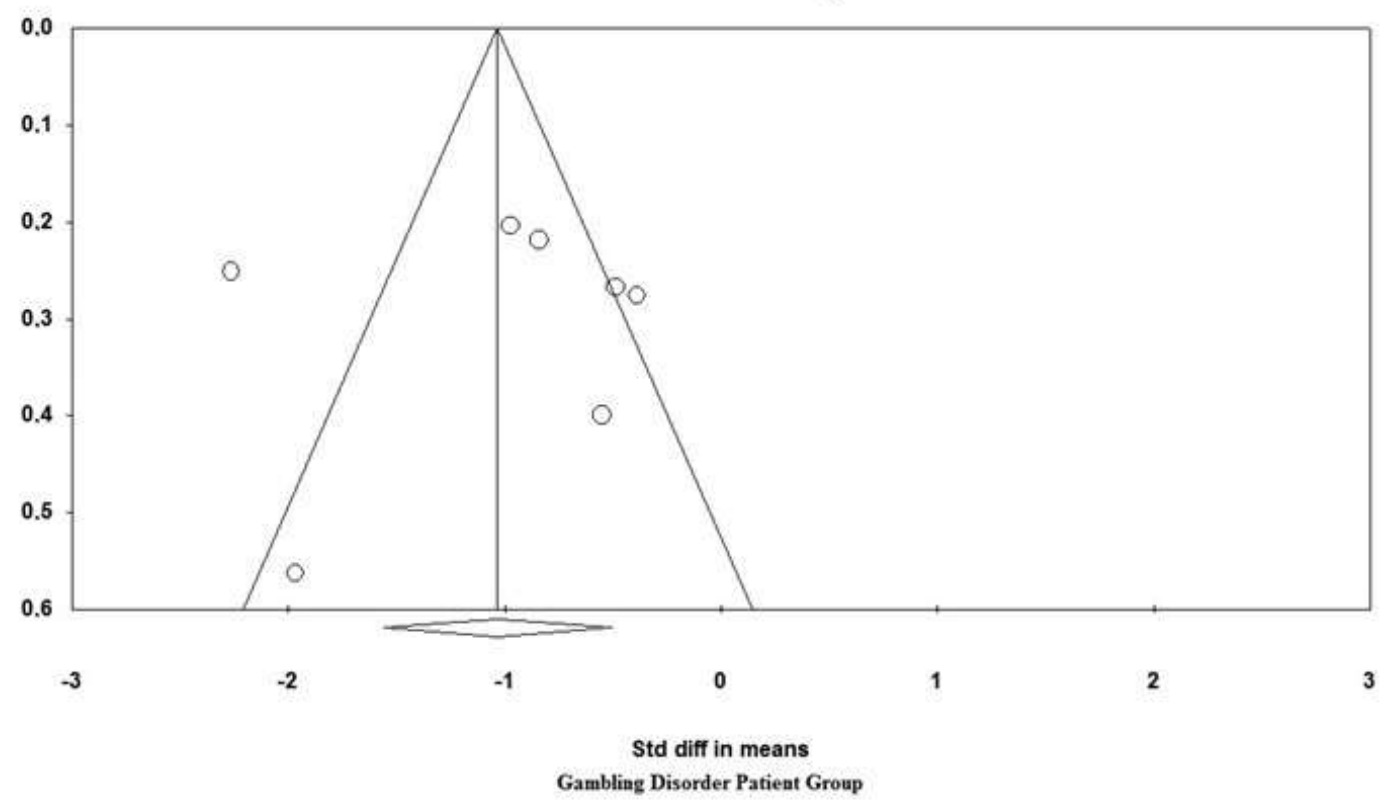

Figure 5: Funnel Plot of Standard Error by standardized mean differences in GD group 


\subsection{Moderator and covariate analysis}

Overall 23 contrasts provided data for moderator analysis. Based on the model that incorporated the differences between patient groups and HCs regarding age (coefficient: $0.0270, p=0.48$ ) the proportion of males (coefficient: $0.0049, p=0.46$ ) and level of education in the sample (coefficient: $0.0521, p=0.50$ ) and the age of the treatment groups (coefficient: $0.0164, p=0.39$ ). None of the moderator variables had a significant effect on decision making deficit indicated by the $p$-value. We also tested each moderator separately. Since no significant difference was detected in heterogeneity between the two patient groups, the analyses were conducted on the full sample in order to increase the power of the analyses. Age difference between patient groups and HCs had no significant $p$-value (coefficient: $0.0098, p=0.72$ ). Age of the patient groups had no significant $p$-value either (coefficient: $0.0202, p=0.24)$. The proportion of gender in the sample was also tested and did not differ significantly (coefficient: $0.0048, p=0.41$ ); the level of education showed no significant $p$ value as well (coefficient: $0.0236, p=0.67$ ).

\section{STUDY II}

2.1 Demographic data and prevalence of gambling disorder symptoms in the sample

More than two-third $(76 \%, \mathrm{~N}=79$ out of 103$)$ of the participants were male. The mean age of participants was 45.7 years (SD = 10.35; age: $21-69)$. In total, $78.7 \%$ of the sample completed secondary education and $21.4 \%$ completed graduate education. Close to one third $(31.1 \%)$ of the sample $(\mathrm{N}=32)$ scored 1 or more points on the SOGS with scores ranging between 1 and 14 points (mean $=4.69, \mathrm{SD}=3.5$ ); 18 people categorised as problematic gamblers and 14 as probable pathological gamblers. The two groups did not differ in gender, age, education, IQ, start of alcohol consumption or abstinence during the last 30 days, but the AUD+Gambling group was characterised by more severe alcohol use and longer lifetime alcohol consumption (see Table 4). 
Table 4: Demographic, alcohol and gambling related characteristics of the sample

\begin{tabular}{|c|c|c|c|}
\hline & $\operatorname{AUD}(\mathbf{N}=71)$ & $\begin{array}{l}\text { AUD+Gambling } \\
\qquad(\mathbf{N}=\mathbf{3 2})\end{array}$ & \\
\hline Gender $(M \%)$ & $73.2 \%$ & $84.3 \%$ & $\begin{array}{c}X^{2}(1)=1.530, p= \\
0.216)^{\mathrm{a}}\end{array}$ \\
\hline $\begin{array}{c}\text { Education\% } \\
\text { (primary/secondary/higher) }\end{array}$ & $5.6 \% / 70.4 \% / 24 \%$ & $12.5 \% / 71.9 \% / 15.6 \%$ & $\begin{array}{c}X^{2}(2)=2.060, p= \\
0.357)^{\mathrm{a}}\end{array}$ \\
\hline Age $(S D)$ & $45.41(9.612)$ & $46.28(11.967)$ & $\begin{array}{c}t(101)=-0.394, p= \\
0.694^{\mathrm{b}}\end{array}$ \\
\hline $\begin{array}{l}\text { Start of alcohol misuse in years } \\
\qquad(S D)\end{array}$ & $25.50(9.337)$ & $22.34(11.449)$ & $\begin{array}{c}t(100)=1.473, p= \\
0.144^{\mathrm{b}}\end{array}$ \\
\hline $\begin{array}{l}\text { Lifetime alcohol consumption in } \\
\text { years }(S D)\end{array}$ & $16.88(9.856)$ & $21.63(11.935)$ & $\begin{array}{c}t(100)=-2.109, p= \\
0.037^{b}\end{array}$ \\
\hline $\begin{array}{l}\text { Abstinence duration during last } \\
\qquad 30 \text { days }(S D)\end{array}$ & $22.134(15.571)$ & $17.594(9.641)$ & $\begin{array}{c}t(101)=0.521, p= \\
0.131^{\mathrm{b}}\end{array}$ \\
\hline WAIS-IV Ttl IQ (SD) & $92.32(14.78)$ & $89.75(15.917)$ & $\begin{array}{c}t(101)=0.798, p= \\
0.427^{\mathrm{b}}\end{array}$ \\
\hline AUDIT Total $(S D)$ & $23.62(7.316)$ & $27.48(6.961)$ & $\begin{array}{c}t(100)=-2.489, p= \\
0.014^{b}\end{array}$ \\
\hline SCL-90-R GSI (SD) & $0.083(0.064)$ & $0.110(0.074)$ & $\begin{array}{c}t(101)=-1.856, p= \\
0.066^{\mathrm{b}}\end{array}$ \\
\hline
\end{tabular}

AUD: Alcohol use disorder patient group, AUD+Gambling: Alcohol use disorder patient group with problem or pathological gambling symptoms, SD: standard deviation, WAIS Ttl IQ: Wechsler Adult Intelligence Scale IV total score, AUDIT: Alcohol Use Disorder Identification Test, SCL-90-R: Symptom Checklist-90-R ${ }^{\text {a }}$ Chi-square test, ${ }^{\mathrm{b}}$ Independent sample $t$-test

2.2 Exploratory correlation matrix and group differences between gambling symptom severity and demographic variables, psychopathological symptoms and measures of impulsivity

Partial correlation with age, lifetime alcohol consumption and SCL-90-R GSI as covariates were conducted to explore the associations between these variables, where the severity of gambling symptoms (SOGS scores) showed significant correlation with the BIS Total Score $(r=0.278, p=0.006)$, while Impulsive aggression measured with the BPAQ Total score $(\mathrm{r}=0.128, p=0.209)$, and neuropsychological measures of impulsivity, as the number of correct responses in the WCST $(\mathrm{r}=-0.046, p=0.658)$, the number of total errors in the WCST $(r=0.054, p=0.602)$, the number of perseverative errors in the WCST $(r=-0.068$, $p=0.510)$, the DDT $(\mathrm{r}=-0.118, p=0.254)$, the total win on the IGT $(\mathrm{r}=-0.005, p=0.962)$, the number of advantageous choices on the IGT ( $\mathrm{r}=0.065, p=0.529)$, the number of 
disadvantageous choices on the IGT $(r=-0.065, p=0.529)$ and the IGT net score $(r=0.065$, $p=0.529$ ) did not show significant connection with the severity of gambling symptoms (see Annex 2).

Based on the associations explored in the correlation matrix, independent sample $t$ tests were conducted to explore group differences in the subscales of the BIS. Figure 6 illustrates that the AUD+Gambling group had higher scores in the BIS Nonplanning $(t(100)=$ -3.024, $p=0.003$, Cohen's $d=-0.634)$ and the BIS Total scores $(t(100)=-2.635, p=0.010$, Cohen's $d=-0.555)$, and a tendency toward significance in the BIS Motor Impulsivity $(t(100)$ $=-1.767, p=0.080$, Cohen's $d=-0.371)$.

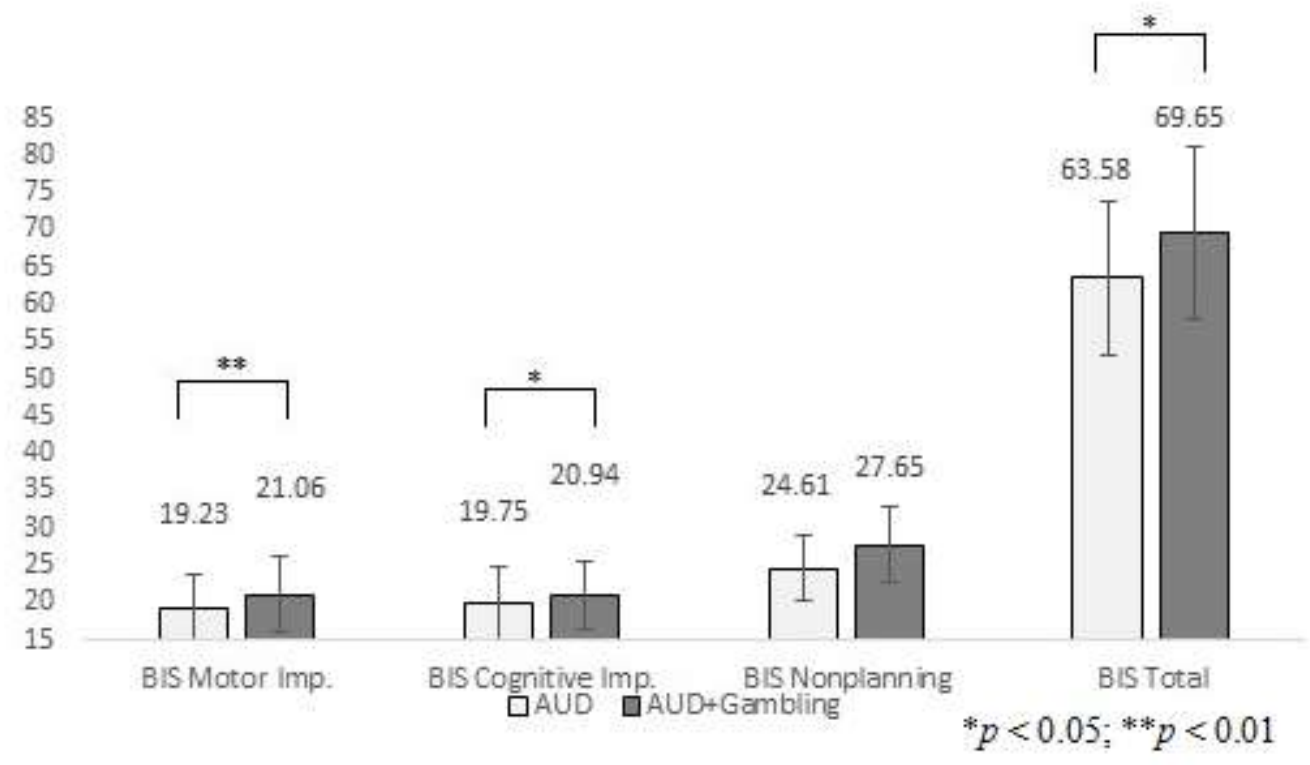

Figure 6: Group differences in Barratt Impulsivity Scale

AUD: chronic alcohol use disorder patients; AUD+Gambling: alcohol use disorder patients with problem or pathological gambling symptoms; BIS Motor Imp.: Barratt Impulsivity Scale Motor Impulsivity subscale; BIS Cognitive Imp.: Barratt Impulsivity Scale Cognitive Impulsivity subscale; BIS Nonplanning: Barratt Impulsivity Scale Nonplanning subscale; BIS Total: Barratt Impulsivity Scale Total score; the columns represent mean values, the error bars standard deviation

\subsection{The effect of demographic variables, psychopathological symptoms and measures of} impulsivity on gambling symptoms

To explore the effect of demographic variables, psychopathological symptoms and measures of impulsivity on gambling symptoms, we performed two binary logistic regressions with forward stepwise regression method with AUD vs. AUD+Gambling as 
dependent variable. The first binary logistic regression was performed with age, gender, IQ measured by the WAIS-IV and SCL-90-R GSI as covariates. The BPAQ Total score, the BIS Total score, the number of correct responses in the WCST, the number of total errors in the WCST, the number of perseverative errors in the WCST, the DDT score, the total win on the IGT, the number of advantageous choices on the IGT, the number of disadvantageous choices on the IGT and the IGT net score on the likelihood that patients have problem gambling symptoms were entered as predictors. Assumption of collinearity was tested and resulted in no indication of multicollinearity (Tolerance below 0.865 and VIF below 3.645 for every variable in the model). The baseline model $(\mathrm{B}=-0.895$, S.E. $=0.220$, Wald $\chi 2(1)=16.507, p$ $\leq 0.001$, OR $=0.408)$ had an accuracy of $71.0 \%$ overall percentage. The binary logistic regression model was statistically significant $\left(\chi 2(1)=7.324, p=0.007 ; \mathrm{R}^{2}=0.101\right.$; HosmerLemeshow goodness-of-fit test: $\chi 2(8)=2.703, p=0.958$ ). Increasing BIS Total score was associated with the increased likelihood of having problem gambling symptoms $(\mathrm{B}=0.057$, S.E. $=0.022$, Wald $\chi 2(1)=6.631, p=0.010, \mathrm{OR}=1,059,95 \% \mathrm{CI}=1.014-1.105)$ while all the other variables had a non-significant effect in the final model.

In the second binary logistic regression the BIS and BPAQ subscales were also included besides the total scores, namely: BIS Motor Impulsivity Score, BIS Cognitive Impulsivity Score, BIS Nonplanning Score, BPAQ Verbal Aggression Score, BPAQ Physical Aggression, BPAQ Hostility score and BPAQ Anger score. Additionally, the number of correct responses in the WCST, the number of total errors in the WCST, the number of perseverative errors in the WCST, the DDT score, the total win on the IGT, the number of advantageous choices on the IGT, the number of disadvantageous choices on the IGT and the IGT net score were included as predictors with age, gender, IQ measured by the WAIS-IV and SCL-90-R GSI as covariates. Assumption of collinearity was tested and resulted in no indication of multicollinearity (Tolerance below 0.819 and VIF below 3.808 for every variable in the model). The baseline model $(\mathrm{B}=-0.895$, S.E. $=0.220$, Wald $\chi 2(1)=16.507, p$ $\leq 0.001$, OR $=0.408)$ had an accuracy of $70.0 \%$ overall percentage. The binary logistic regression model was statistically significant $\left(\chi 2(1)=8.914, p=0.003 ; \mathrm{R}^{2}=0.122\right.$; HosmerLemeshow goodness-of-fit test: $\chi 2(7)=9.121, p=0.244)$. Increasing BIS Nonplanning score was associated with the increased likelihood of having problem gambling symptoms $(\mathrm{B}=$ 0.143 , S.E. $=0.051$, Wald $\chi 2(1)=7.844, p=0.005, \mathrm{OR}=1,154,95 \% \mathrm{CI}=1.044-1.275)$, while all the other variables had a non-significant effect in the final model. 


\section{DISCUSSION}

AUD and GD show similarities concerning their clinical picture, aetiology, comorbidity, physiology, treatment prognosis and symptomatology, from which higher impulsivity is a core feature in both disorders. The present thesis aimed to focus on the comprehensive evaluation of the different aspects of impulsivity and their expression in sole diagnoses and comorbid occurrence of AUD and GD. Firstly, aggregated clinical data were analysed in a systematic-review based quantitative meta-analysis, concentrating on the comparison of diagnosed GD and AUD patients compared to matched HCs on a neurocognitive task (the IGT) measuring one dimension of cognitive impulsivity: impulsive decision-making. Then clinical data was evaluated to assess the differences in terms of the different aspects of impulsivity examined with a range of objective and subjective measurement tests to determine whether the co-occurrence of GD symptoms in chronic AUD patients show more severe deficits in impulse control.

The first hypothesis $\left(\mathrm{H}_{1}\right)$ that both AUD and GD patients show impaired decisionmaking measured with the IGT compared to matched HC group was confirmed. In a systematic literature search-based meta-regression of AUD and GD patients' decision-making characteristics measured by a computerized neuropsychological task, the IGT, deficits were detected in both patient groups compared to matched HC participants. The reason behind the focus on the IGT was that this neurocognitive task is one of the most widely accepted and clinically used computerized neurocognitive measurement option that models real-life decision-making under laboratory circumstances (Bechara et al., 1997; Bechara, 2005). The issue of cognitive impulsivity measured by the IGT is widely addressed in case of mental disorders. Scientific literature up to date is not consistent in the presence of significant differences in the IGT performance of patients with schizoaffective disorder or schizophrenia compared to matched HC groups (Alves and Rozenthal, 2006; Pedersen et al., 2017), while results showed that bipolar disorder patients are prone to make riskier choices compared to HC groups (Edge et al., 2013). Impaired decision-making is also a dominant feature of depressive disorders (Must et al., 2013), as it is in addictive disorders.

Our results are in line with previous literature focusing on the use of other neurocognitive tasks measuring cognitive impulsivity as well (e.g. the Delay Discounting Task or the Cambridge Gambling Task) in which AUD and GD patients exhibit significantly and substantially larger deficits in cognitive impulsivity than matched control participants (Lawrence et al., 2009; Ioannidis et al., 2017). Concerning results with the use of the IGT, impaired decision-making is suggested to be present in the expression of poor IGT 
performance in AUD (Andó et al., 2012). This may be linked to the disturbance of global executive functions in AUD that is strongly associated with relapse, which is imminent during the recovery processes. Relapse prevention is a key factor in the maintenance of long-term abstinence, although many AUD patients fail to succeed in sustaining prolonged abstinence. This might be reasoned with dysfunctional decision-making presented in choosing disadvantageous long-term strategies by favouring immediate rewards accompanied by the disregard of future negative consequences. Since the IGT is considered to be a direct assessment of measuring cognitive impulsivity and it is a clinically accepted assessment task in addictive disorders (Bechara, 2005), this deficit displayed on the IGT of AUD and GD patients contrasted with $\mathrm{HC}$ groups might be considered as a predictive factor of their longterm objectives and lifestyle choices. AUD patients' deteriorated performance on the IGT was linked to premorbid personality traits as well, like higher novelty seeking $(\mathrm{r}=-0.46, p<0.05)$ or higher reward dependence $(r=-0.50, p<0.005)$ (Tomassini et al., 2012). AUD comorbid with maladaptive personality traits were also connected with impairment on the IGT performance, in which cluster B personality disorders depicted the poorest performance (Dom et al., 2006). Concerning GD contrasted with matched HC group, significantly higher sensation seeking was detected, which was strongly associated with impaired decisionmaking, thus cognitive impulsivity (Linnet et al., 2006); however, the effect of concomitant diagnosed personality disorders and GD on cognitive impulsivity is yet to be explored.

The second hypothesis $\left(\mathrm{H}_{2}\right)$ that AUD and GD patient groups can be differentiated in terms of decision-making measured by the IGT net scores was also confirmed, since both patient groups showed deficits in decision-making; moreover, the presence of impaired decision-making was even larger in the case of GD patients than in the AUD group. Analysis of aggregated clinical data suggest that not the substance itself might lie in the background of the deficit detected in decision-making, but rather other dysfunctions of cognitive and personality traits that are associated with addictive disorders. There is extensive data on AUD and GD sharing common underlying mechanisms as higher impulsivity (Lawrence et al., 2009; Verdejo-García et al., 2007), and both addictions are proved to increase the likelihood of presenting similar comorbid psychiatric disorders (e.g. anxiety or mood disorders) (Lister et al., 2015). GD and AUD patients show strong similarities in their neurocognitive profiles as well: traits like impaired decision-making and cognitive impulsivity are also considered to be vulnerability factors preceding the two addictions. To support this, two prospective studies indicated that the existence of higher trait impulsivity predicts later emergence of AUD (Verdejo-García et al., 2008), as well as GD (Slutske et al., 2005). 
Despite literature indicating differences in age, gender and education in the course and patterns of AUD (Crum et al., 1993; Hingson et al., 2006; Wilsnack et al., 2009) and GD (Brunborg et al., 2016; Ibáñez et al., 2001; Jiménez-Murcia et al., 2010) as well, in the present aggregated clinical data, moderator and covariate analysis of these variables did not yield results for sufficiently supporting their impact in the detected deficit of decision-making. The presence of significant heterogeneity might be the reason for that across and within the samples. Besides age, gender and education, several other factors, such as intellect, the length of abstinence and other psychopathological characteristics like the levels of depressive symptoms or anxiety may contribute to the emergence and understanding of the characteristics of cognitive impulsivity in AUD and GD. Since some clinical data (like the length of abstinence, AUD/GD symptom severity etc.) were insufficient for evaluation in the present meta-analysis, it is advised for future clinical studies to account for and report these data with potentially confounding effects. Thus, further empirical and meta-analytical scientific results are necessary to ascertain the issue of the potential effects of psychopathological and socio-demographic characteristics on decision-making, thus cognitive impulsivity in AUD and GD.

The present meta-analysis corroborates previous scientific literature that impairment in decision-making, as a core symptom in addictive disorders, may not be directly connected to the substance consumption itself, since it is not only present, but is independently and more characteristically displayed in a non-substance-related, behavioural disorder (GD), than in a substance-related dependence (AUD). This supports the recent re-placement in the Diagnostic and Statistical Manual of Mental Disorders (DSM-5) (American Psychiatric Association, 2013) where GD was moved from Impulse control disorders to Substance-related and addictive disorders (Petry et al., 2014) as the first addictive disorder not related to a chemical compound in this category. GD seems to bear similarities in the diagnostic criteria of other substance-related disorders in terms of addicted patients continuing to pursue an activity (either being gambling activity or alcohol consumption) despite its negative outcomes on the long run, and disregarding that it result in adverse effects on their mental, physical and socioeconomic state. A parallel is notable between the mechanism described before and the preference in short-term gain versus long-term loss or long-term gain versus short-term loss measured with the IGT.

The third hypothesis $\left(\mathrm{H}_{3}\right)$ that the prevalence of comorbid GD symptoms with AUD fits in with international trends in inpatient treatment unit for AUD was also confirmed, since $31.1 \%$ of chronic AUD patients reported concomitant GD symptoms. Several large, 
population-based studies conducted in English-speaking regions of the world and in Western Europe reported a huge overlap (17-33\%, depending on the exact study) between alcohol and gambling addictions and vice versa (Daghestani et al., 1996; Lesieur et al., 1991; Lorains et al., 2011; Petry et al., 2005). These numbers greatly exceed the prevalence data of $0.5-2 \%$ reported in studies of general populations (Colishaw et al., 2014; Kessler et al., 2008).

The fourth hypothesis $\left(\mathrm{H}_{4}\right)$ that long-term AUD patients with comorbid GD symptoms express higher symptom severity of substance use and psychopathological symptoms was partially confirmed. In the clinical sample evaluated in this thesis, patients with comorbid AUD and GD symptoms reported more severe alcohol use and longer lifetime alcohol consumption, but psychopathological symptom severity was only significant on the level of tendency. The quantity of alcohol intake and its relationship with the severity of GD symptoms has already been documented in previous studies (Abbott et al., 2004; Smith et al., 2010); additionally, the excessive number of GD patients with lifetime alcohol problems has also been reported (Kausch, 2003). Similarly, in another study that assessed GD symptom severity and engagement in gambling in AUD patients seeking treatment, it was shown that elevated levels of GD symptoms positively correlated with more serious AUD, and also with higher levels of psychopathological symptom severity (Stinchfield, Kushner \& Winters, 2005). The reason for the significance on the level of tendency in the present study might lie in the fact that both patient groups were chronic, long-term AUD patients, in which case higher psychopathological symptom severity is a documented aspect both in case of subclinical (Carbia et al., 2016) and clinically diagnosed samples (Iwanicka, Gerhant \& Olajossy, 2017).

The fifth hypothesis $\left(\mathrm{H}_{5}\right)$ that long-term AUD patients with comorbid GD symptoms present higher levels of trait impulsivity, choice impulsivity, impulsive aggression and impulsive decision-making was partially confirmed, since only higher trait impulsivity proved to be present in chronic AUD comorbid with GD symptoms. Patients with chronic AUD receiving inpatient treatment for their alcohol dependence were assessed with or without GD symptoms on an extensive battery comprising of objective and subjective measurements of four sub-dimensions of impulsivity. The traditional trait concept of impulsivity was evaluated by the BIS, as it is the most widely used measure of trait impulsivity in clinical setting. The ability to delay immediate rewards and postpone gratifications was measured by the DDT, being a widely accepted approach for evaluating impulsive choices. Impulsive aggression was assessed with the BPAQ, while deficits in response inhibition and decision-making as forms of cognitive impulsivity, were examined with the WCST and the IGT. After controlling for 
age, SCL-90-R GSI and lifetime alcohol consumption, the severity of GD symptoms showed significant positive correlation with trait impulsivity, while only trait impulsivity proved to be associated with the increased likelihood of having concomitant GD symptoms. Generally, these findings could not be reasoned by the result of group differences in age, and they were not mediated by the assessed differences in psychiatric symptom severity or years of alcohol consumption reported either.

Regardless of intelligence, age, gender and psychopathological symptom severity, solely higher trait impulsivity and its non-planning subdimension was linked to the cooccurrence of concomitant GD symptoms in chronic AUD. This connection conforms to previous scientific literature in terms that in functional imaging studies, the nonplanning dimension of impulsivity evaluated by the BIS strongly correlated with registered volumes of the left anterior cingulate gyrus, the right middle cingulate gyrus, left middle cingulate and frontal gyrus and the right orbitofrontal gyrus (Cho et al., 2013). Frontal lobe dysfunction is regarded as a leading symptom in alcohol-related impairment of the brain caused by the prolonged misuse of alcohol (Sullivan, Harris \& Pfefferbaum, 2010), thus the risk of the emergence of comorbid GD in chronic AUD is especially high.

There is vast clinical data on the negative consequences of elevated trait impulsivity in AUD and GD (expressed in clinical and subclinical forms as well). Keough \& O'Connor (2016) reported that higher trait impulsivity measured with the BIS proved to be a risk factor in excessive, problematic alcohol use. Concerning diagnosed AUD, epidemiological (Johnson, Turner \& Iwata, 2003), cross-sectional (Evren et al., 2012; Goudriaan et al., 2005) and longitudinal studies (Evren et al., 2014; Rubio et al., 2008) thoroughly demonstrated the maladaptive function of elevated trait impulsivity in AUD. In case of GD, Yan et al. (2016) compared the impulsivity profiles of recreational, at-risk and problem gamblers and reported higher BIS motor and attentional impulsivity in case of at-risk and problem gambling individuals. Similarly, in case of established GD diagnosis, multiple studies demonstrated higher levels of trait impulsivity compared to HC group (Choi et al., 2013; Lee et al., 2017).

Choice impulsivity is a dominant aspect in AUD and GD as well. Petry (2001) reported a more rapid discounting of delayed rewards in case of AUD patients; moreover, Alessi \& Petry (2003) demonstrated a link between GD symptom severity and higher impulsive choice-making in a delay discounting task. Petry \& Casarella (1999) studied substance abusers with and without GD and reported that substance abusers with GD symptoms discounted delayed rewards more rapidly than patients without GD symptoms. Despite being previously verified that GD have an additive effect on delay discounting, in 
Study II, delay discounting was not associated with GD symptom severity nor did it increase the likelihood of having GD symptoms in case of chronic AUD patients. A possible reason for that may be that patients suffering from addictive disorders with or without GD symptoms are reported to discount delayed rewards significantly more rapidly than HC individuals, thus addictive disorders themselves are also linked to higher discounting rates (Kirby et al., 1999; Madden et al., 1997).

Poor response inhibition related to impulsive aggression is also affected by acute alcohol consumption (Filmore \& Blackburn, 2002; Filmore, Marczinski \& Bowman, 2005; Marczinski \& Filmore, 2005) and chronic misuse of alcohol and AUD as well (Hildebrandt et al., 2004; Kamarajan et al., 2005). Response inhibition and its control is mediated by the limbic/thalamic and prefrontal/orbito-frontal cortical circuits, and the impairment of these interconnected circuitries might induce excessive aggressive response, i.e. impulsive aggression (Metzger et al., 2010; Parke \& Griffith, 2005). In the present thesis, impulsive aggression measured with the BPAQ correlated with GD symptom severity, which conform to previous scientific results, as a growing number of studies have established a connection between GB and aggressive behaviour (94). In a longitudinal study of adolescent males tested at three ages (12, 15 and 18 years) aggressive behaviour measured with the BPAQ was directly connected to the emergence of increasing alcohol consumption, but a connection between alcohol use leading to later aggressive behaviour was not established (White, Brick \& Hansell, 1993). Similarly, clinically diagnosed AUD and GD patients were documented to report increased aggressive impulses as well (Korman et al., 2008; McPherson \& Martin, 2010).

Despite that deficits of response inhibition and risky decision-making as forms of impulsivity have previously been documented to play key roles in addictive processes, our results did not conform to these. Since in case of chronic AUD patients with or without GD symptoms, no differences on the IGT or the WCST could be identified, nor did these contribute to the likelihood of developing GD symptoms. Gambling tasks involving rewards and punishments like the IGT and tasks assessing executive frontal lobe functions like the WCST have been extensively utilized to evaluate deficits in response inhibition and decisionmaking capacities and in individuals with AUD and GD. Contrasted with HC group, AUD and GD patients both had deficits on the IGT, they selected the larger immediate reward more frequently despite having a larger concomitant punishment (Cavedini et al., 2002; Cordovil et al., 2010; Forbush et al., 2008; Murray et al., 2015). Furthermore, chronic long-term alcohol consumption is also documented to be associated with lower performance on executive 
function tests like the WCST (Guillot et al., 2010; Houston et al., 2014). As another assessment of cognitive flexibility, it was also documented that GD patients exhibited more perseverative errors on the WCST (Potenza, Kosten \& Rounsaville, 2001). Results presented in this thesis do not conform to these findings, which may be reasoned with the consequences of prolonged alcohol consumption on those cortical regions that play central roles in decisionmaking and response inhibition (Goudriaan et al., 2005; Lawrence et al., 2009; Potenza et al., 2001), which in the present case did not result in an even more predominant decline in neurocognitive performance of AUD patients with comorbid GD symptoms contrasted with patients with sole AUD. Concerning the lack of differences besides trait impulsivity, but not in other facets of impulsivity evaluated in this thesis, meta-analyses highlight that impulsivity is not a unitary construct, but has a multifaceted nature with distinct manifestations in AUD and GD compared to HC populations, demonstrating a general deficit in inhibitory control, thus impulsive cognitive disfunction (Ioannidis et al., 2017; Stephan et al., 2017).

Several limitations need to be addressed regarding the studies comprising the present thesis. Concerning Study I, given that plenty of studies yielded from the systematic literature search did not report the IGT net scores, so these data could not be incorporated in the metaanalysis of the aggregated clinical data. Additionally, for increasing the power of the metaanalysis and effect size, more clinical studies with empirical raw data of IGT net scores should be incorporated. Because of the higher level of heterogeneity in the analysed sample, a future meta-analysis with more incorporated studies available would be able to create subgroups within the AUD and GD patient groups based on their symptom severity. Based on the articles' text, another factor that contributed to bias unable to be completely controlled, was the possibility of overlap among control groups, i.e. that HC groups matched to AUD patient groups might contain individuals affected by GD symptoms to some extent. In this manner, HC participants without GD might be subjected to some extent of AUD as well.

Since decision-making is only a facet of the multidimensional construct of impulsivity, it can be assessed with the use of several different paradigms, from these the IGT is only one of them. Multiple valid and reliable objective and subjective assessment methods and computerized neurocognitive tasks are available, but in this study only the IGT was incorporated. Another limitation is that only articles published in English were incorporated in the present systematic literature search and quantitative meta-analysis. Besides completely omitting non-English articles, multiple strategies are available for addressing literature written any other language than English; however, in the present work, papers written in any other languages were excluded automatically, which may implicate language bias (Grégoire et al., 
1995). Additionally, another important limitation to note is that number of studies investigating both AUD and GD was scarce (Bottesi et al., 2015; Kräplin et al., 2014) and regardless of the high comorbidity previously documented in scientific literature (Feigelman et al., 1998; Petry et al., 2005; Stinchfield et al., 2005; Welte et al., 2001), such study that incorporated decision-making performance measured with the IGT of patients diagnosed both with AUD and GD could not be identified. Conducting an empirical study in this manner could be key in gaining a more detailed picture of the aspects of cognitive impulsivity of these two disorders and could be key in the assessment of any potentially additive effect of simultaneous AUD and GD on more characteristic impairment of decision-making.

Regarding Study II, several limitations should be considered when interpreting the results. Since impulsivity is considered to be a complex and multidimensional construct, there is no unanimously accepted consensus regarding its definition and operationalization of each component, even the exact number of its components and their separability are of question. In the present thesis, impulsivity is operationalized by self-measurement tests and computerized neuropsychological tasks assessing four dimensions: trait impulsivity, choice impulsivity, impulsive aggression and impulsive decision-making; hence, the present work is limited by this notion.

Also, impulsive aggression was assessed with the use of the BPAQ, which, although related to impulsiveness, is not considered to be an explicit measurement of impulsivity, because it contains elements of hostility and premeditated antisocial behaviour. Additionally, taking into account the cross-sectional nature of the present study, conclusions regarding a potential causal relationship between the distinct facets of impulsivity and comorbid AUD and GD symptoms cannot be drawn. In this work, only a link between more severe alcohol consumption, longer lifetime alcohol intake and heightened trait impulsivity could be established in case of AUD patients with comorbid GD symptoms contrasted with sole AUD patients. Since the prolonged problematic use of alcohol leads to more impulsive actions across individuals' life course, it influences both subjective and objective measures of impulsivity. 


\section{CONCLUSION AND MAIN FINDINGS}

Impulsivity is regarded as a key concept in AUD and GD as well, that provided the basis of the empirical research on which the present thesis is based on. Firstly, the two disorders were separately assessed in one aspect of impulsivity, decision-making as a form of cognitive impulsivity measured by the IGT to determine differences between the two disorders compared to HC groups. Additionally, although in scientific literature impulsivity is regarded as a multidimensional construct, no previous studies have incorporated a comprehensive assessment of impulsivity in chronic AUD patients with or without comorbid GD symptoms before.

Based on these, novel findings of the present thesis are the following:

I. Decision-making deficit is apparent in both alcohol use disorder (AUD) and gambling disorder (GD).

II. Impaired decision making is not linked to substance use itself, but rather to addictive behaviour, since the decision-making deficit is more expressed in GD than in AUD.

III. The prevalence of comorbid GD symptoms in AUD was 31.1\%, which fits in with international trends.

IV. Chronic AUD patients with GD symptoms exhibited more severe alcohol use and longer lifetime alcohol consumption.

V. Gambling symptom severity was associated with higher trait impulsivity in chronic AUD.

VI. Higher trait impulsivity increased the risk of problem gambling in chronic AUD.

The establishment of a link between comorbid GD and AUD in a given population might enhance clinicians' ability to make therapies more personalized, and could lead to the enhancement of treatment efficacy as well, resulting in the lowering of treatment costs and the reduce of relapse rates (Grant \& Chamberlain, 2006; Winters \& Cushner, 2003). Future research could benefit from the longitudinal evaluation of the distinct dimensions of impulsivity in chronic AUD populations. Taking special attention to its different presentations in AUD comorbid with GD symptoms may contribute to clearing directions for providing target-specific and effective treatment approaches. Integrating the comprehensive assessment of GD symptoms into the treatment regime of AUD patients might help in reducing the additive adverse effects of comorbid AUD and GD related problems. 


\section{ACKNOWLEDGEMENTS}

First, I would like to express my gratitude to my supervisors, Prof. Dr. Zoltán Janka for his impeccable professional guidance, and to Dr. Bálint Andó, who fostered and shaped my scientific thinking in the past nine years, for which I am deeply grateful. I am also indebted to Dr. Anikó Maráz for introducing me to the world of meta-analyses, and for her thorough support and essential help in research methodology. I would like to thank for the cooperation of everyone with whom I had the opportunity to work together: Prof. Dr. Zsolt Demetrovics, Mara Richman, Dr. Ildikó Demeter and Dr. Sándor Rózsa, for their contribution to the works on which the present thesis is based on. I would also like to express my gratitude to my co-workers at the Addiction Ward, Department of Psychiatry, University of Szeged, for their support and help in patient recruitment, and also for my colleagues at the Affective and Psychotherapy Ward for helping me with the creation of a suitable environment for the formation of this thesis. Last, bur far from least, I would like to express my deepest gratitude towards my mother for all the support she provided me during my entire life, and to all my loved ones, who not just tolerated, but accompanied and supported me physically, mentally and verbally along this sometimes rugged road. 


\section{REFERENCES}

Abbott, M.W., Williams, M.M., \& Volberg, R.A. (2004). A prospective study of problem and regular nonproblem gamblers living in the community. Subst Use Misuse. 39(6), 85584.

Andó, B., Must, A., Kurgyis, E., Szkaliczki, A., Drótos, G., Rózsa, S., Szikszay, P., Horváth, S., Janka, Z., \& Almos, P.Z. (2012). Personality traits and coping compensate for disadvantageous decision-making in long-term alcohol abstinence. Alcohol Alcohol. $47,18-24$.

Alessi, S.M., \& Petry, N.M. (2003). Pathological gambling severity is associated with impulsivity in a delay discounting procedure. Behav Processes. 64(3), 345-54.

Alves, G.S., \& Rozenthal, M. (2006). Neuropsychological assessment of decision-making prefrontal circuits in schizophrenia: a systematic review of the literature. Rev Psiquiatr Rio Gd Sul. 28, 330-41.

American Psychiatric Association. (2013). Diagnostic and Statistical Manual of Mental Disorders (5th ed.). Arlington, VA: American Psychiatric Association.

Aragay, N., Barrios, M., Ramirez-Gendrau, I., Garcia-Caballero, A., Garrido, G., RamosGrille, I., Galindo, Y., Martin-Dombrowski, J., \& Vallès, V. (2018). Impulsivity profiles in pathological slot machine gamblers. Compr Psychiatry. 83, 79-83.

Barratt, E.S., Stanford, M.S., Dowdy, L., Liebman, M.J., \& Kent, T.A. (1999). Impulsive and premeditated aggression: a factor analysis of self-reported acts. J Psychiatr Res. 86(2), $163-73$.

Bechara, A. (2005). Decision making, impulse control and loss of willpower to resist drugs: a neurocognitive perspective. Nat Neurosci. 8(11), 1458-63.

Bechara, A., Damasio, A.R., Damasio, H., \& Anderson, S.W. (1994). Insensitivity to future consequences following damage to human prefrontal cortex. Cognition. 50(1-3), $7-$ 15.

Bechara, A., Damasio, H., Tranel, D., \& Damasio, A.R. (1997). Deciding advantageously before knowing the advantageous strategy. Science. 275(5304), 1293-5.

Begg, C.B., \& Mazumdar, M. (1994). Operating characteristics of a rank correlation test for publication bias. Biometrics. 50, 1088-1101.

Berg, E.A. (1948). A simple objective technique for measuring flexibility in thinking. J Gen Psychol. 39, 15-22.

Berlin, H.A., \& Hollander, E. (2008). Understanding the differences between impulsivity and compulsivity. Psychiatr Times. 25(8), 58. 
Bischof, A., Meyer, C., Bischof, G., John, U., Wurst, F.M., Thon, N., Lucht, M., Grabe, H.J., \& Rumpf, H.J. (2015). Suicidal events among pathological gamblers: the role of comorbidity of axis I and axis II disorders. J Psychiatr Res. 225(3), 413-9.

Blair, R.J. (2016). The neurobiology of impulsive aggression. J Child Adolesc Psychopharmacol. 26(1), 4-9.

Blaszczynski, A. (2010). Instrumental tool or drug: Relationship between attitudes to money and problem gambling. Addict Res Theor. 18(6), 681-91.

Blaszczynski, A., Steel, Z., \& McConaghy, N. (1997). Impulsivity in pathological gambling: The antisocial impulsivist. Addiction. 92, 75-87.

Blaszczynski, A., Walker, M., Sharpe, L., \& Nower, L. (2008). Withdrawal and tolerance phenomenon in problem gambling. J Gambl Stud. 8(2), 179-92.

Borenstein, M., Hedges, L.V., \& Higgins, J.P.T. (2017). Introduction to Meta-Analysis (Accessed 3 October 2016). URL: http://eu.wiley.com/WileyCDA/ WileyTitle/productCd-EHEP002313.html

Bottesi, G., \& Ghisi, M. (2014). Pathological gambling: compulsive-impulsive spectrum disorder, behavioural addiction or both? Phenotypic and endophenotypic evidence. Psychopathol Rev. 1(1), 2-25.

Bottesi, G., Ghisi, M., Ouimet, A.J., Tira, M.D., \& Sanavio, E. (2015). Compulsivity and impulsivity in pathological gambling: Does a dimensional-transdiagnostic approach add clinical utility to DSM-5 classification? J Gambl Stud. 31(3), 825-47.

Brand, M., Fujiwara, E., Borsutzky, S., Kalbe, E., Kessler, J., \& Markowitsch, H. J. (2005). Decision-making deficits of Korsakoff patients in a new gambling task with explicit rules: Associations with executive functions. Neuropsychology. 19, 267-77.

Braun, B., Ludwig, M., Sleczka, P., Buhringer, G., \& Kraus, L. (2014). Gamblers seeking treatment: Who does and who doesn't? J Behav Addict. 3(3), 189-98.

Buja, A., Lion, C., Scioni, M., Vian, P., Genetti, B., Vittadello, F., Sperotto, M., Simeoni, E., \& Balso, V. (2017). SOGS-RA gambling scores and substance use in adolescents. J Behav Addict. 6(3), 425-33.

Buss, A.H., \& Perry, M. (1992). The aggression questionnaire. J Pers Soc Psychol. 63(3), $452-9$.

Butler, S.F., Budman, S.H., Goldman, R.J., Newman, F.L., Beckley, K.E., Trottier, D., \& Cacciola, J.S. (2001). Initial validation of a computer-administered Addiction Severity Index: the ASI-MV. J Soc Psychol Addict Behav. 15(1), 4-12. 
Carbia, C., Corral, M., García-Moreno, L.M., Cadaveira, F., \& Caamaño-Isorna, F. (2016). Early alcohol use and psychopathological symptoms in university students. Psicothema. 28(3), 247-52.

Cavedini, P., Riboldi, G., Keller, R., D’Annucci, A., \& Bellodi, L. (2002). Frontal lobe dysfunction in pathological gambling patients. Biol Psychiatry. 51(4), 334-41.

Charney, D.A., Zikos, E., \& Gill, K.J. (2010). Early recovery from alcohol dependence: Factors that promote or impede abstinence. J Subst Abuse Treat. 38(1), 42-50.

Cherek, D. (1981). Effects of smoking different doses of nicotine on human aggressive behavior. Psychopharmacology. 75, 339-345.

Cherek, D.R. (1992). Manual for Point Subtraction Aggression Paradigm: A computer program to measure aggressive responding in human subjects under controlled laboratory conditions. Houston: University of Texas Health Science Center.

Cho, S.S., Pellecchia, G., Aminian, K., Ray, N., Segura, B., Obeso, I., \& Strafella, A.P. (2013). Morphometric correlation of impulsivity in medial prefrontal cortex. Brain Topogr. 26(3), 479-87.

Choi, J.S., Kim, H.S., Kim, G.Y., Jeon, Y., Park, S.M., Lee, J.Y., Jung, H.Y., Sohn, B.K., Choi, J.S., \& Kim, D.J. (2014). Similarities and differences among Internet gaming disorder, gambling disorder and alcohol use disorder: A focus on impulsivity and compulsivity. J Behav Addict. 3(4), 246-53.

Cloninger, C.R., Svrakic, D.M., \& Przybeck, T.R. (1993). A psychobiological model of temperament and character. Arch Gen Psychiatry. 50, 975-90.

Cohen, J. (1988). Statistical Power Analysis for the Behavioral Sciences. Hillsdale, N.J.: L. Erlbaum Associates.

Comprehensive Meta-Analysis Software (CMA). (Accessed 13 October 2017). URL https:// www.meta-analysis.com/

Cordovil, D.S.U.M., Luminet, O., Cortesi, M., Constant, E., Derely, M., \& De Timary, P. (2010). Distinct effects of protracted withdrawal on affect, craving, selective attention and executive functions among alcohol-dependent patients. Alcohol Alcohol. 45, 241-6.

Cowlishaw, S., Merkouris, S., Chapman, A. \& Radermacher, H. (2014). Pathological and problem gambling in substance use treatment: a systematic review and meta-analysis. J Subst Abuse Treat. 46, 98-105. 
Cunningham-Williams, R.M., Cottler, L.B., Compton, W.M., \& Spitznagel, E.L. (1998). Taking chances: problem gamblers and mental health disorders--results from the St. Louis Epidemiologic Catchment Area Study. Am J Public Health. 88(7), 1093-6.

Cunningham-Williams, R.M., Cottler, L.B., Compton, W.M., Spitznagel, E.L., \& BenAbdallah, A. (2000). Problem gambling and comorbid psychiatric and substance use disorders among drug users recruited from drug treatment and community settings. $\mathbf{J}$ Gamb Stud. 16(4), 347-75.

Crum, R.M., Helzer, J.E., \& Anthony, J.C. (1993). Level of education and alcohol abuse and dependence in adulthood: a further inquiry. Am J Public Health. 83, 830-7.

Daghestani, A.N., Elenz, E., \& Crayton, J.W. (1996). Pathological gambling in hospitalized substance abusing veterans. J Clin Psychiatry. 57(8), 360-3.

Denis, C., Fatséas, M., \& Auriacombe, M. (2012). Analyses related to the development of DSM-5 criteria for substance use related disorders: 3. An assessment of pathological gambling criteria. Drug Alcohol Dep. 122(1-2), 22-7.

de Wit, H. (2009). Impulsivity as a determinant and consequence of drug use: a review of underlying processes. Addict Biol. 14, 22-31.

Derogatis, L.R. (1986). SCL-90-R Administration, Scoring and Procedures Manual II for the Revised Version and Other Instruments of the Psychopathology Rating Scale Series. Towson, MD: Clinical Psychometric Research.

Dickman, S.J. (1990). Functional and dysfunctional impulsivity: Personality and cognitive correlates. J Pers Soc Psychol. 58(1), 95-102.

Dom, G., De Wilde, B., Hulstijn, W., Van Den Brink, W., \& Sabbe, B. (2006). Decisionmaking deficits in alcohol-dependent patients with and without comorbid personality disorder. Alcohol Clin Exp Res. 30, 1670-7.

Dougherty, D.M., Mathias, C.W., Marsh, D.M., \& Jagar, A.A. (2005). Laboratory behavioral measures of impulsivity. Behav Res Methods. 37(1), 82-90.

Dussault, F., Brendgen, M., Vitaro, F., Wanner, B., \& Tremblay, R.E. (2011). Longitudinal links between impulsivity, gambling problems and depressive symptoms: a transactional model from adolescence to early adulthood. J Child Psychol Psychiatry. $52(2), 130-8$.

Duvarci, I., \& Varan, A. (2000) Descriptive features of Turkish pathological gamblers. Scand J Psychol. 41, 253-60. 
Edge, M.D., Johnson, S.L., Ng, T., \& Carver, C.S. (2013). Iowa Gambling Task performance in euthymic bipolar I disorder: a meta-analysis and empirical study. J Affect Disord. $150,115-22$.

Egger, M., Smith, G.D., Schneider, M., \& Minder, C. (1997). Bias in meta-analysis detected by a simple, graphical test. Brit Med J. 315, 629-34.

El-Guebaly, N. (2006). Epidemiological association between gambling behaviour, substance use \& mood and anxiety disorders. J Gamble Stud. 22, 275-87.

Evenden, J.L. (1999). Varieties of impulsivity. Psychopharmacology. 146, 348-61.

Everitt, B.J., \& Robbins, T.W. (2005). Neural systems of reinforcement for drug addiction: from actions to habits to compulsion. Nat Neurosci. 8(11),1481-9.

Evren, C., Durkaya, M., Evren, B.J., Dalbudak, E., \& Cetin, R. (2012). Relationship of relapse with impulsivity, novelty seeking and craving in male alcohol-dependent inpatients. Drug Alcohol Rev. 31(1), 81-90.

Evren, C., Yilmaz, A., Can, Y., Bozkurt, M., \& Evren, B. (2012). EPA-0489 - Status of impulsivity in 12-month follow-up among male alcohol dependent inpatients. Eur Psychiatry. 29, 1.

Eysenck, S.B.G., \& Eysenck, H.J. (1977). The place of impulsiveness in a dimensional system of personality description. Br J Soc Clin Psychol. 16, 57-68.

Feigelman, W., Wallisch, L.S., \& Lesieur, H.R. (1998). Problem gamblers, problem substance users, and dual-problem individuals: An epidemiological study. Am J Public Health. $88(3), 467-70$.

Fein, G., Bachman, L., Fisher, S., \& Davenport, L. (1990). Cognitive impairment in abstinent alcoholics. West J Med. 152(5), 531-7.

Fillmore, M.T., \& Blackburn, J. (2002). Compensating for alcohol-induced impairment: alcohol expectancies and behavioral disinhibition. J Stud Alcohol. 63(2), 237-46.

Fillmore, M.T., Marczinski, C.A., \& Bowman, A.M. (2005). Acute tolerance to alcohol effects on inhibitory and activational mechanisms of behavioral control. J Stud Alcohol. 66(5), 663-72.

Figner, B., Mackinlay, R.J., Wilkening, F., \& Weber, E.U. (2009). Affective and deliberative processes in risky choice: Age differences in risk taking in the Columbia Card Task. $\mathrm{J}$ Exp Psychol Learn Mem Cogn. 35, 709-30.

Fineberg, N.A., Chamberlain, S.R., Goudriaan, A.E., Stein, D.J., Vanderschuren, L.J., Gillan, C.M., Shekar, S., Gorwood, P.A., Voon, V., Morein-Zamir, S., Denys, D., Sahakian, B.J., Moeller, F.G., Robbins, T.W., \& Potenza, M.N. (2014). New developments in 
human neurocognition: clinical, genetic, and brain imaging correlates of impulsivity and compulsivity. CNS Spectr. 19(1), 69-89.

Forbush, K.T., Shaw, M., Graeber, M.A., Hovick, L., Meyer, V.J., Moser, D.J., Bayless, J., Watson, D., \& Black, D.W. (2008). Neuropsychological characteristics and personality traits in pathological gambling. CNS Spectr. 13, 306-15.

Franken, I.H.A., van Strien, J.W., Nijs, I., \& Muris, P. (2008). Impulsivity is associated with behavioral decision-making deficits. Psychiatry Res. 158(2), 155-63.

Gerevich, J., Bácskai, E., \& Czobor, P. (2007). The generalizability of the Buss-Perry Aggression Questionnaire. Int J Methods Psychiatr Res. 16(3), 124-36.

Gerevich, J., Bácskai, E., \& Rózsa, S. (2006). Prevalence of hazardous alcohol use. Psychiatr Hung. 21(1), 45-56.

Goudriaan, A.E., Oosterlaan, J., de Beurs, E., \& van den Brink, W. (2005). Decision making in pathological gambling: a comparison between pathological gamblers, alcohol dependents, persons with Tourette syndrome, and normal controls. Brain Res Cogn Brain Res. 23(1), 137-51.

Grant, D.A., \& Berg, E.A. (1948). A behavioral analysis of degree of reinforcement and ease of shifting to new responses in a Weigl-type card-sorting problem. J Exp Psychol. 38(4), 404-11.

Grant, J.E., \& Chamberlain, S.R. (2004). Impulsive action and impulsive choice across substance and behavioral addictions: cause or consequence? Addict Behav. 39(11), 1632-9.

Grant, J.E., \& Chamberlain, S.R. (2020). Gambling and substance use: Comorbidity and treatment implications. Prog Neuropsychopharmacol Biol Psychiatry. 99, 109852.

Grant, J.E., \& Kim, S.W. (2001). Demographic and clinical features of 131 adult pathological gamblers. J Clin Psychiatry. 62(12), 957-62.

Grégoire, G., Derderian, F., \& Le Lorier, J. (1995). Selecting the language of the publications included in a meta-analysis: is there a Tower of Babel bias? J Clin Epidemiol. 48, 159-63.

Griffiths, M. (1993). Tolerance in gambling: an objective measure using the psychophysiological analysis of male fruit machine gamblers. Addict Behav. 18(3), 365-72.

Guillot, C.R., Fanning, J.R., Bullock, J.S., McCloskey, M.S., \& Berman, M.E. (2010). Effects of alcohol on tests of executive functioning in men and women: A dose response examination. Exp Clin Psychopharmacol. 18(5), 409-17. 
Gyollai, A., Urbán, R., Kun, B., Paksi, B., Arnold, P., Balázs, H., Kökönyei, Gy., Oláh, A., \& Demetrovics, Z. (2011). Problémás és patológiás szerencsejáték Magyarországon: a South Oaks szerencsejáték kérdőiv magyar verziójának (SOGS-HU) hazai alkalmazása. Psychiatr Hung. 26(4), 230-40.

Harding, A.J., Wong, A., Svoboda, M., Kril, J.J., \& Halliday, G.M. (1997). Chronic alcohol consumption does not cause hippocampal neuron loss in humans. Hippocampus. 7(1), 78-87.

Hasin, D.S., \& Grant, B.F. (2015). The National Epidemiologic Survey on Alcohol and Related Conditions (NESARC) Waves 1 and 2: review and summary of findings. Soc Psychiatry Psychiatr Epidemiol. 50(11), 1609-40.

Hasin, D.S., Stinson, F.S., Ogburn, E., \& Grant, B.F. (2007). Prevalence, correlates, disability, and comorbidity of DSM-IV alcohol abuse and dependence in the United States: results from the National Epidemiologic Survey on Alcohol and Related Conditions. Arch Gen Psychiatry. 64(7), 830-42.

Hentges, R.F., Shaw, D.S., \& Wang, M.T. (2018). Early childhood parenting and child impulsivity as precursors to aggression, substance use, and risky sexual behavior in adolescence and early adulthood. Dev Psychopathol. 30(4), 1305-19.

Hildebrandt, H., Brokate, B., Eling, P., \& Lanz, M. (2004). Response shifting and inhibition, but not working memory, are impaired after long-term heavy alcohol consumption. Neuropsychology. 18(2), 203-11.

Hingson, R.W., Heeren, T., \& Winter, M.R. (2006). Age at drinking onset and alcohol dependence: age at onset, duration, and severity. Arch Pediatr Adolesc Med. 160, 739-46.

Hodgins, D.C., \& Holub, A. (2015). Components of impulsivity in gambling disorder. Int J Ment Health Addict. 13(6), 699-711.

Holden, C. (2010). Behavioral addictions debut in proposed DSM-V. Science. 327(5968), 935.

Houston, R.J., Derrick, J., Leonard, K., Testa, M., Quigley, B., \& Kubiak, A. (2014). Effects of heavy drinking on executive cognitive functioning in a community sample. Addict Behav. 39(1), 345-9.

Ibáñez, A., Blanco, C., Donahue, E., Lesieur, H.R., Pérez de Castro, I., Fernández-Piqueras, J., \& Sáiz-Ruiz, J. (2001). Psychiatric comorbidity in pathological gamblers seeking treatment. Am J Psychiatry. 158(10), 1733-5.

IBM Corp. (2016). IBM SPSS Statistics for Windows. Armonk, NY: IBM Corp. 
Ioannidis, K., Hook, R., Wickham, K., Grant, J.E., \& Chamberlain, S.R. (2017). Impulsivity in gambling disorder and problem gambling: A meta-analysis. Am J Drug Alcohol Abuse. 43(1), 24-43.

Iwanicka, K., Gerhant, A., \& Olajossy, M. (2017). Psychopathological symptoms, defense mechanisms and time perspectives among subjects with alcohol dependence (AD) presenting different patterns of coping with stress. PeerJ. 5, e3576.

Jacob, L., Haro, J.M., \& Koyanagi, A. (2018). Relationship between attention-deficit hyperactivity disorder symptoms and problem gambling: A mediation analysis of influential factors among 7,403 individuals from the UK. J Behav Addict. 7(3), 78191.

Johnson, S.L., Turner, R.J., \& Iwata, N. (2003). BIS/BAS levels and psychiatric disorder: An epidemiological study. J Psychopathol Behav Assess. 25(1), 25-36.

Kalischuk, R.G. (2010). Cocreating life pathways: Problem gambling and its impact on families. Family J. 18(1), 7-17.

Kamarajan, C., Porjesz, B., Jones, K.A., Choi, K., Chorlian, D.B., Padmanabhapillai, A., Rangaswamy, M., Stimus, A.T., \& Begleiter, H. (2005). Alcoholism is a disinhibitory disorder: neurophysiological evidence from a Go/No-Go task. Biol Psychol. 69(3), 353-73.

Kausch, O. (2003). Patterns of substance abuse among treatment-seeking pathological gamblers. J Subst Abuse Treat. 25(4), 263-70.

Kavoussi, R., Armstead, P., \& Coccaro, E. (1997). The neurobiology of impulsive aggression. Psychiat Clin North Am. 20(2), 395-403.

Kessler, R.C., Crum, R.M., Warner, L.A., Nelson, C.B., Schulenberg, J., \& Anthony, J.C. (1997). Lifetime co-occurrence of DSM-III-R alcohol abuse and dependence with other psychiatric disorders in the National Comorbidity Survey. Arch Gen Psychiatry. 54(4), 313-21.

Kessler, R.C., Hwang, I., LaBrie, R., Petukhova, M., Sampson, N.A., Winters, K.C. \& Schaffer, H.J. (2008). The prevalence and correlates of DSM-IV pathological gambling in the National Comorbidity Survey Replication. Psychol Med. 38, 1351-60.

Keef, S.P., Roberts, \& L.A. (2004). The meta-analysis of partial effect sizes. Br J Math Stat Psychol. 57 (1), 97-129.

Kim, Y.-T., Sohn, H., \& Jeong, J. (2011). Delayed transition from ambiguous to risky decision making in alcohol dependence during Iowa Gambling Task. Psychiatry Res. 190, 297-303. 
Kirby, K.N., \& Maraković, N.N. (1996). Delay-discounting probabilistic rewards: Rates decrease as amounts increase. Psychon Bull Rev. 3(1), 100-4.

Kirby, K.N., Petry, N.M., \& Bickel, W.K. (1999). Heroin addicts have higher discount rates for delayed rewards than non-drug-using controls. J Exp Psychol Gen. 128(1), 78-87.

Koob, G.F. (2000). Animal models of craving for ethanol. Addiction. 95(Suppl 2), S73-S81.

Korman, L., Collins, J., Littman-Sharp, N., Skinner, W., McMain, S., \& Mercado, V. (2008). Randomized control trial of an integrated therapy for comorbid anger and gambling. $\mathbf{J}$ Soc Psychother Res. 18(4), 454-65.

Kozak, K., Lucatch, A.M., Lowe, D.J.E., Balodis, I.M., MacKillop, J., \& George, T.P. (2019). The neurobiology of impulsivity and substance use disorders: implications for treatment. Ann N Y Acad Sci. 1451(1), 71-91.

Kräplin, A., Bühringer, G., Oosterlaan, J., van den Brink, W., Goschke, T., \& Goudriaan, A.E. (2014). Dimensions and disorder specificity of impulsivity in pathological gambling. Addict Behav. 39, 1646-51.

Kun, B., Balázs, H., Arnold, P., Paksi, B., \& Demetrovics, Z. (2012). Gambling in Western and Eastern Europe: the example of Hungary. J Gambl Stud. 28(1), 27-46.

Lawrence, A.J., Luty, J., Bogdan, N.A., Sahakian, B.J., \& Clark, L. (2009). Problem gamblers share deficits in impulsive decision-making with alcohol-dependent individuals. Addiction. 104, 1006-15.

Leblond, J., Ladouceur, R., \& Blaszczynski, A. (2003). Which pathological gamblers will complete treatment? Br J Clin Psychol. 42(2), 205-9.

Lee, J.Y., Park, S.M., Kim, Y.J., Kim, D.J., Choi, S.W., Kwon, J.S., \& Choi, J.S. (2017). Resting-state EEG activity related to impulsivity in gambling disorder. J Behav Addict. 6(3), 387-95.

Ledgerwood, D.M., \& Petry, N.M. (2006). What do we know about relapse in pathological gambling? Clin Psychol Rev. 26(2), 216-28.

Ledgerwood, D.M., Alessi, S.A., Phoenix, N., \& Petry, N.M. (2009). Behavioral assessment of impulsivity in pathological gamblers with and without substance use disorder histories versus healthy controls. Drug Alcohol Depend. 105, 89-96.

Lejuez, C.W., Read, J.P., Kahler, C.W., Richards, J.B., Ramsey, S.E., Stuart, G.L., Strong, D.R., \& Brown, R.A. (2002). Evaluation of a behavioral measure of risk taking: The Balloon Analogue Risk Task (BART). J Exp Psychol Appl. 8(2), 75-84. 
Lesieur, H.R., \& Blume, S.B. (1987). The South Oaks Gambling Screen (SOGS): a new instrument for the identification of pathological gamblers. Am J Psychiatry. 144(9), $1184-8$.

Lesieur, H.R., \& Rosenthal, R.J. (1991). Pathological gambling: A review of the literature (prepared for the American Psychiatric Association task force on DSM-IV committee on disorders of impulse control not elsewhere classified). J Gambl Stud. 7(1), 5-39.

Levin, I.P., \& Hart, S.S. (2003). Risk preferences in young children: Early evidence of individual differences in reaction to potential gains and losses. J Behav Decis Mak. 16(5), 397-413.

Lister, J.J., Milosevic, A., \& Ledgerwood, D.M. (2015). Psychological characteristics of problem gamblers with and without mood disorder. Can J Psychiatry Rev Can Psychiatr. 60, 369-76.

Logan, G. D. (1994). On the ability to inhibit thought and action: A users' guide to the stop signal paradigm. In Dagenbach, D., \& Cart, T. H. (Eds.). Inhibitory Processes in Attention, Memory, and Language. San Diego: Academic Press, pp. 189-239.

Lorains, F.K., Cowlishaw, S., \& Thomas, S.A. (2011). Prevalence of comorbid disorders in problem and pathological gambling: systematic review and meta-analysis of population surveys. Addict Abingdon Engl. 106(3), 490-8.

Mazur, J.E. (1987). An adjusting procedure for studying delayed reinforcement. In: The Effect of Delay and of Intervening Events on Reinforcement Value. Hillsdale, NJ, US: Lawrence Erlbaum Associates, Inc.

Mackey, S., Chaarani, B., Kan, K.J., Spechler, P.A., Orr, C., Banaschewski, T., Barker, G., Bokde, A.L.W., Bromberg, U., Büchel, C., Cattrell, A., Conrod, P.J., Desrivières, S., Flor, H., Frouin, V., Gallinat, J., Gowland, P., Heinz, A., Ittermann, B., Paillère Martinot, M.L., Artiges, E., Nees, F., Papadopoulos-Orfanos, D., Poustka, L., Smolka, M.N., Jurk, S., Walter, H., Whelan, R., Schumann, G., Althoff, R.R., \& Garavan, H. (2017). Brain regions related to impulsivity mediate the effects of early adversity on antisocial behavior. Biol Psychiatry. 82(4), 275-82.

MacKillop, J. (2013). Integrating behavioral economics and behavioral genetics: delayed reward discounting as an endophenotype for addictive disorders. J Exp Anal Behav. 99(1), 14-31.

Madden, G.J., Petry, N.M., Badger, G.J., \& Bickel, W.K. (1997). Impulsive and self-control choices in opioid-dependent patients and non-drug-using control participants: drug and monetary rewards. Exp Clin Psychopharmacol. 5(3), 256-62. 
Manning, V., Dowling, N.A., Lee, S., Rodda, S., Garfield, J.B.B., Volberg, R., Kulkarni, J., \& Lubman, D.I. (2017). Problem gambling and substance use in patients attending community mental health services. J Behav Addict. 6(4), 678-88.

Marczinski, C.A., \& Fillmore, M.T. (2005). Compensating for alcohol-induced impairment of control: effects on inhibition and activation of behavior. Psychopharmacology. 181(2), $337-46$.

Matta, A. d., Gonçalves, F. L., \& Bizarro, L. (2012). Delay discounting: Concepts and measures. Psychol Neurosci. 5(2), 135-46.

McCarthy, D.M., Niculete, M.E., Treloar, H.R., Morris, D.H., \& Bartholow, B.D. (2012). Acute alcohol effects on impulsivity: Associations with drinking and driving behavior. Addict Abingdon Engl. 107(12), 2109-14.

McPherson, A., \& Martin, C. (2010). A contemporary review of the alcohol/aggression relationship and the Buss-Perry Aggression Questionnaire for use in an alcohol dependent population. J Aggress Confl Peace Res. 2(1), 45-56.

Metzger, C.D., Eckert, U., Steiner, J., Sartorius, A., Buchmann, J.E., Stadler, J., Tempelmann, C., Speck, O., Bogerts, B., Abler, B., \& Walter, M. (2010). High field FMRI reveals thalamocortical integration of segregated cognitive and emotional processing in mediodorsal and intralaminar thalamic nuclei. Front Neuroanat. 4, 138.

Miranda, R., MacKillop, J., Meyerson, L.A., Justus, A., \& Lovallo, W.R. (2009). Influence of antisocial and psychopathic traits on decision-making biases in alcoholics. Alcohol Clin Exp Res. 33, 817-25.

Mitchell, S.H. (1999). Measures of impulsivity in cigarette smokers and non-smokers. Psychopharmacology. 146, 455-64.

Mitchell, J.M., Fields, H.L., D’Esposito, M., \& Boettiger, C.A. (2005). Impulsive responding in alcoholics. Alcohol Clin Exp Res. 29(12), 2158-69.

Mitchell, M.R., \& Potenza, M.N. (2014). Addictions and personality traits: Impulsivity and related constructs. Curr Behav Neurosci Rep. 1(1), 1-12.

Moeller, F.G., Barratt, E.S., Dougherty, D.M., Schmitz, J.M., \& Swann, A.C. (2001). Psychiatric aspects of impulsivity. Am J Psychiatry. 158(11), 1783-93.

Morasco, B.J., Pietrzak, R.H., Blanco, C., Grant, B.F., Hasin, D., \& Petry, N.M. (2006). Health problems and medical utilization associated with gambling disorders: Results from the National Epidemiologic Survey on Alcohol and Related Conditions. Psychosom Med. 68, 976-84. 
Muñoz, M., Ausín, B., Santos-Olmo, A.B., Härter, M., Volkert, J., Schulz, H., Sehner, S., Dehoust, M.C., Suling, A., Wegscheider, K., Canuto, A., Crawford, M.J., Grassi, L., Da Ronch, C., Hershkovitz, Y., Quirk, A., Rotenstein, O., Shalev, A.Y., Strehle, J., Weber, K., Wittchen, H.U., \& Andreas, S. (2018). Alcohol use, abuse and dependence in an older European population: Results from the MentDis_ICF65+ study. PLoS One. 13(4), e0196574.

Murray, D.E., Durazzo, T.C., Mon, A., Schmidt, T.P., \& Meyerhoff, D.J. (2015). Brain perfusion in polysubstance users: relationship to substance and tobacco use, cognition, and self-regulation. Drug Alcohol Depend. 150, 120-8.

Must, A., Horvath, S., Nemeth, V.L., \& Janka, Z. (2013). The Iowa Gambling Task in depression - What have we learned about sub-optimal decision-making strategies? Front Psychol. 4, 732.

Newman, J.P., Patterson, C.M., Howland, E.W., \& Nichols, S.L. (1990). Passive avoidance in psychopaths: The effects of reward. Pers Individ Differ. 11, 1101-14.

Moher, D., Liberati, A., Tetzlaff, J., \& Altman, D.G. (2009). Preferred reporting items for systematic reviews and meta-analyses: the PRISMA statement. Ann Intern Med. 151, 264-69.

Paksi, B., Demetrovics, Z., Magi, A., \& Felvinczi, K. (2017). [The methodology and sample description of the National Survey on Addiction Problems in Hungary 2015. Neuropsychopharmacol Hung. 19(2), 55-85.

Park, S., Cho, M.J., Jeon, H.J., Lee, H.W., Bae, J.N., Park, J.I., Sohn, J.H., Lee, Y.R., Lee, J.Y., \& Hong, J.P. (2010). Prevalence, clinical correlations, comorbidities, and suicidal tendencies in pathological Korean gamblers: results from the Korean Epidemiologic Catchment Area Study. Soc Psychiatry Psychiatr Epidemiol. 45(6), 621-9.

Parke, A., \& Griffiths, M.D. (2005). Aggressive behaviour in adult slot machine gamblers: A qualitative observational study. Int J Ment Health Addict. 2, 50-8.

Patton, J.H., Stanford, M.S., \& Barratt, E.S. (1995). Factor structure of the Barratt Impulsiveness Scale. J Clin Psychol. 51(6), 768-74.

Pedersen, A., Göder, R., Tomczyk, S., \& Ohrmann, P. (2017). Risky decision-making under risk in schizophrenia: a deliberate choice? J Behav Ther Exp Psychiatry. 56, 57-64.

Perry, J.L., \& Carroll, M.E. (2008). The role of impulsive behavior in drug abuse. Psychopharmacology. 200(1), 1-26.

Peters, J., \& Büchel, C. (2011). The neural mechanisms of inter-temporal decision-making: understanding variability. Trends Cogn Sci. 15(5), 227-39. 
Petry, N.M. (2001). Delay discounting of money and alcohol in actively using alcoholics, currently abstinent alcoholics, and controls. Psychopharmacology. 154(3), 243-50.

Petry, N.M., \& Casarella, T. (1999). Excessive discounting of delayed rewards in substance abusers with gambling problems. Drug Alcohol Depend. 56(1), 25-32.

Piper, B.J., Mueller, S.T., Geerken, A.R., Dixon, K.L., Kroliczak, G., Olsen, R.H.J., \& Miller, J.K. (2015). Reliability and validity of neurobehavioral function on the Psychology Experimental Building Language test battery in young adults. PeerJ. 3, e1460.

Potenza, M.N., Kosten, T.R., \& Rounsaville, B.J. (2001). Pathological gambling. J Am Med Assoc. 286(2), 141-4.

Rachlin, H., Raineri, A., \& Cross, D. (1991). Subjective probability and delay. J Exp Anal Behav. 55(2), 233-44.

Rash, C.J., Weinstock, J., \& Petry, N.M. (2011). Drinking patterns of pathological gamblers before, during, and after gambling treatment. Psychol Addict Behav. 25(4), 664-74.

Rácz, J., Pogány, C., \& Máthé-Árvay, N. (2002). Az EuropASI (Addikció Súlyossági Index) magyar nyelvü változatának reliabilitás- és validitásvizsgálata. Magy Pszichol Szle. 57(4), 587-603.

Rehm, J., Anderson, P., Barry, J., Dimitrov, P., Elekes, Z., Feijão, R., Frick, U., Gual, A., Gmel, G. Jr., Kraus, L., Marmet, S., Raninen, J., Rehm, M.X., Scafato, E., Shield, K.D., Trapencieris, M., \& Gmel, G. (2015). Prevalence of and potential influencing factors for alcohol dependence in Europe. Eur Addict Res. 21(1), 6-18.

Reilly, C., \& Smith, N. (2015). The evolving definition of pathological gambling in the DSM5. National Center of Responsible Gaming. 1-5.

Reynolds, B., \& Schiffbauer, R. (2004). Measuring state changes in human delay discounting: an experiential discounting task. Behav Processes. 67(3), 343-56.

Rochat, L., Billieux, J., Gagnon, J., \& Van der Linden, M. (2018). A multifactorial and integrative approach to impulsivity in neuropsychology: insights from the UPPS model of impulsivity. J Clin Exp Neuropsychol. 40(1), 45-61.

Rogers, R.D., Everitt, B. J., Baldacchino, A., Blackshaw, A.J., Swainson, R., Wynne, K., Baker, N.B., Hunter, J., Carthy, T., Booker, E., London, M., Deakin, J.F.W., Sahakian, B.J., \& Robbins, T.W. (1999). Dissociable deficit s in the decision-making cognition of chronic amphetamine abusers, opiate abusers, patients with focal damage to prefrontal cortex, and tryptophan-depleted normal volunteers: evidence for monoaminergic mechanisms. Neuropsychopharmacology. 20, 322-39. 
Rosenthal, R. \& Lesieur, H. (1993). Self-reported withdrawal symptoms and pathological gambling. In Eadington, W.R., \& Cornelius, J. (eds). Gambling Behaviour and Problem Gambling. Institute for the study of gambling and commercial gaming. Reno, NV: pp. 337-46.

Rosnow, R.L., Rosenthal, R., \& Rubin, D.B. (2000). Contrasts and correlations in effect-size estimation. Psychol Sci. 11(6), 446-53.

Rózsa, S., \& Kö, N. (2008). A Wechsler intelligenciateszttel szerzett nemzetközi eredmények áttekintése. In: A WISC-IV gyermek intelligenciateszt magyar kézikönyve: Hazai tapasztalatok, vizsgálati eredmények és normák. Budapest: OS Hungary Tesztfejlesztő Kft. p. 9-16.

Rubio, G., Jiménez, M., Rodríguez-Jiménez, R., Martínez, I., Ávila, C., Ferre, F., JiménezArriero, M.A., Ponce, G., \& Palomo, T. (2008). The role of behavioral impulsivity in the development of alcohol dependence: A 4-Year follow-up study. Alcohol Clin Exp Res. 32(9), 1681-7.

Rubio, G., Martínez-Gras, I., \& Manzanares, J. (2009). Modulation of impulsivity by topiramate: implications for the treatment of alcohol dependence. $\mathrm{J}$ Clin Psychopharmacol. 29(6), 584-9.

Salvatore, J.E., Gottesman, I.I., \& Dick, D.M. (2015). Endophenotypes for alcohol use disorder: An update on the field. Curr Addict Rep. 2(1), 76-90.

Saunders, J.B., Aasland, O.G., Babor, T.F., de la Fuente, J.R., \& Grant, M. (1993). Development of the Alcohol Use Disorders Identification Test (AUDIT): WHO Collaborative Project on Early Detection of Persons with Harmful Alcohol Consumption-II. Addict Abingdon Engl. 88(6):791-804.

Sellman, J.D., Adamson, S., Robertson, P., Sullivan, S., \& Coverdale, J. (2002). Gambling in mild-moderate alcohol-dependent outpatients. Subst Use Misuse. 37, 199-213.

Shaffer, H.J., Hall, M.N., \& Vander Bilt, J. (1999). Estimating the prevalence of disordered gambling behavior in the United States and Canada: A research synthesis. Am J Publ Health. 89, 1369-76.

Shiffler, R.E. (1988). Maximum z scores and outliers. Am Stat. 42, 79-80.

Sinz, H., Zamarian, L., Benke, T., Wenning, G.K., \& Delazer, M. (2008). Impact of ambiguity and risk on decision making in mild Alzheimer's disease. Neuropsychology. 46, 2043-55. 
Slutske, W.S., Caspi, A., Moffitt, T.E., \& Poulton, R. (2005). Personality and problem gambling:a prospective study of a birth cohort of young adults. Arch Gen Psychiatry. $62,769-75$.

Slutske, W.S., Eisen, S., True, W.R., Lyons, M.J., Goldberg, J., \& Tsuang, M. (2000). Common genetic vulnerability for pathological gambling and alcohol dependence in men. Arch Gen Psychiatry. 57(7), 666-73.

Slutske, W.S., Ellingson, J.M., Rickmond-Rakerd, L.S., Zhu, G., \& Martin, N.G. (2013). Shared genetic vulnerability for disordered gambling and alcohol use disorder in men and women: Evidence from a national community-based Australian twin study. Twin Res Hum Genet. 16(2), 525-34.

Smith, D., Harvey, P., Battersby, M., Pols, R., Oakes, J., \& Baigent, M. (2010). Treatment outcomes and predictors of drop out for problem gamblers in South Australia: a cohort study. Aust N Z J Psychiatry. 44(10), 911-20.

Stanford, M.S., Houston, R.J., \& Mathias, C.W. (2003). Characterizing aggressive behavior. Assessment. 10, 183-90.

Steel, Z. \& Blaszczynski, A. (1998). Impulsivity, personality disorders and pathological gambling severity. Addiction. 93, 895-905.

Stephan, R.A., Alhassoon, O.M., Allen, K.E., Wollman, S.C., Hall, M., Thomas, W.J., Gamboa, J.M., Kimmel, C., Stern, M., Sari, C., Dalenberg, C.J., Sorg, S.F., \& Grant, I. (2017). Meta-analyses of clinical neuropsychological tests of executive dysfunction and impulsivity in alcohol use disorder. Am J Drug Alcohol Abuse. 43(1), 24-43.

Stevens, A.K., Littlefield, A.K., Talley, A.E., \& Brown, J.L. (2017). Do individuals higher in impulsivity drink more impulsively? A pilot study within a high-risk sample of young adults. Addict Behav. 65, 147-53.

Stinchfield, R., Kushner, M.G., \& Winters, K.C. (2005). Alcohol use and prior substance abuse treatment in relation to gambling problem severity and gambling treatment outcome. J Gambl Stud. 21(3), 273-97.

Stinson, F.S., Grant, B.F., Dawson, D.A., Ruan, W.J., Huang, B., \& Saha, T. (2005). Comorbidity between DSM-IV alcohol and specific drug use disorders in the United States: results from the National Epidemiologic Survey on Alcohol and Related Conditions. Drug Alcohol Depend. 80(1), 105-16.

Storer, J., Abbott, M., \& Stubbs J. (2009). Access or adaptation? A meta-analysis of surveys of problem gambling prevalence in Australia and New Zealand with respect to concentration of electronic gaming machines. Int Gambl Stud. 9(3), 225-44. 
Strong, D.R., \& Kahler, C.W. (2007). Evaluation of the continuum of gambling problems using the DSM-IV. Addiction. 102(5), 713-21.

Sterne, J.A.C., Sutton, A.J., Ioannidis, J.P.A., Terrin, N., Jones, D.R., Lau, J., Carpenter, J., Rücker, G., Harbord, R.M., Schmid, C.H., Tetzlaff, J., Deeks, J.J., Peters, J., Macaskill, P., Schwarzer, G., Duval, S., Altman, D.G., Moher, D., \& Higgins, J.P.T. (2011). Recommendations for examining and interpreting funnel plot asymmetry in meta-analyses of randomised controlled trials. Br Med J. 343, d4002.

Stroup, D.F., Berlin, J.A., Morton, S.C., Olkin, I., Williamson, G.D., Rennie, D., Moher, D., Becker, B.J., Sipe, T.A., \& Thacker, S.B. (2000). Meta-analysis of observational studies in epidemiology: a proposal for reporting: Meta-analysis Of Observational Studies in Epidemiology (MOOSE) group. J Am Med Assoc. 283, 2008-12.

Sullivan, E.V., Harris, R.A., \& Pfefferbaum, A. (2010). Alcohol's effects on brain and behavior. Alcohol Res Health. 33(1-2), 127-43.

Tamminga, C.A., \& Nestler, E.J. (2006). Pathological gambling: focusing on the addiction, not the activity. Am J Psychiatry. 163(2), 180-1.

Tavares, H., Zilberman, M.L., Hodgins, D.C., \& el-Guebaly, N. (2005). Comparison of craving between pathological gamblers and alcoholics. Alcohol Clin Exp Res. 29(8), 1427-31.

Tesch, A. D., \& Sanfey, A. G. (2008). Models and methods in delay discounting. Ann N Y Acad Sci. 1128, 90-4.

Tomassini, A., Struglia, F., Spaziani, D., Pacifico, R., Stratta, P., \& Rossi, A. (2012). Decision making, impulsivity, and personality traits in alcohol-dependent subjects. Am J Addict. 21, 263-7.

Urbán, R,, Arrindell, W.A., Demetrovics, Z., Unoka, Z., \& Timman, R. (2016). Cross-cultural confirmation of bi-factor models of a symptom distress measure: Symptom Checklist-90-Revised in clinical samples. Psychiatry Res. 239, 265-74.

Urbán, R., Kun, B., Farkas, J., Paksi, B., Kökönyei, G., Unoka, Z., Felvinczi, K., Oláh, A., \& Demetrovics, Z. (2014). Bifactor structural model of symptom checklists: SCL-90-R and Brief Symptom Inventory (BSI) in a non-clinical community sample. Psychiatry Res. 216(1), 146-54.

Verdejo-García, A., Lawrence, A.J., \& Clark, L. (2008). Impulsivity as a vulnerability marker for substance-use disorders: review of findings from high-risk research, problem gamblers and genetic association studies. Neurosci Biobehav Rev. 32(4), 777-810. 
Vitaro, F., Arseneault, L., \& Tremblay, R.E. (1999). Impulsivity predicts problem gambling in low SES adolescent males. Addict Abingdon Engl. 94(4), 565-75.

Vitaro, F., Ferland, F., Jacques, C., \& Ladouceur, R. (1998). Gambling, substance use, and impulsivity during adolescence. Psychol Addict Behav. 12, 185-94.

Wechsler, D. (2008). Wechsler Adult Intelligence Scale (4th ed.). USA, San Antonio, TX: Psychological Corporation.

Welte, J., Barnes, G., Wieczorek, W., Tidwell, M.C., \& Parker, J. (2001). Alcohol and gambling pathology among US adults: Prevalence, demographic patterns and comorbidity. J Stud Alcohol. 62, 706-12.

Whiteside, S. P., \& Lynam, D. R. (2001). The Five Factor Model and impulsivity: Using a structural model of personality to understand impulsivity. Pers Individ Differ. 30, $669-89$.

Winters, K.C., \& Kushner, M.G. (2003). Treatment issues pertaining to pathological gamblers with a comorbid disorder. J Gambl Stud. 19(3), 261-77.

World Health Organization, Management of Substance Abuse Team (2018). Global Status Report on Alcohol and Health 2018. [Internet]. 2018 [cited 2020 Febr 28]. Available from: http://www.who.int/substance_abuse/publications/global_alcohol_report/en/

Wray, I., \& Dickerson, M.G. (1981). Cessation of high frequency gambling and 'withdrawal' symptoms. Brit J Addict. 76(4), 401-15.

Zamarian, L., Sinz, H., Bonatti, E., Gamboz, N., \& Delazer, M. (2008). Normal aging affects decisions under ambiguity, but not decisions under risk. Neuropsychology. 22, 64557.

Zorlu, N., Gelal, F., Kuserli, A., Cenik, E., Durmaz, E., Saricicek, A., \& Gulseren, S. (2013). Abnormal white matter integrity and decision-making deficits in alcohol dependence. Psychiatry Res. 214, 382-8.

Zorlu, N., Karavul Ucman, T., Gelal, F., Colak Kalayci, C., Polat, S., Saricicek, A., Kurtgöz Zorlu, P., \& Gulseren, S. (2014). Abnormal white matter integrity in long-term abstinent alcohol dependent patients. Psychiatry Res. 224, 42-8. 


\section{ANNEXES}

Annex 1: detailed description of the 17 studies and the 23 contrasts incorporated in the qualitative meta-analysis

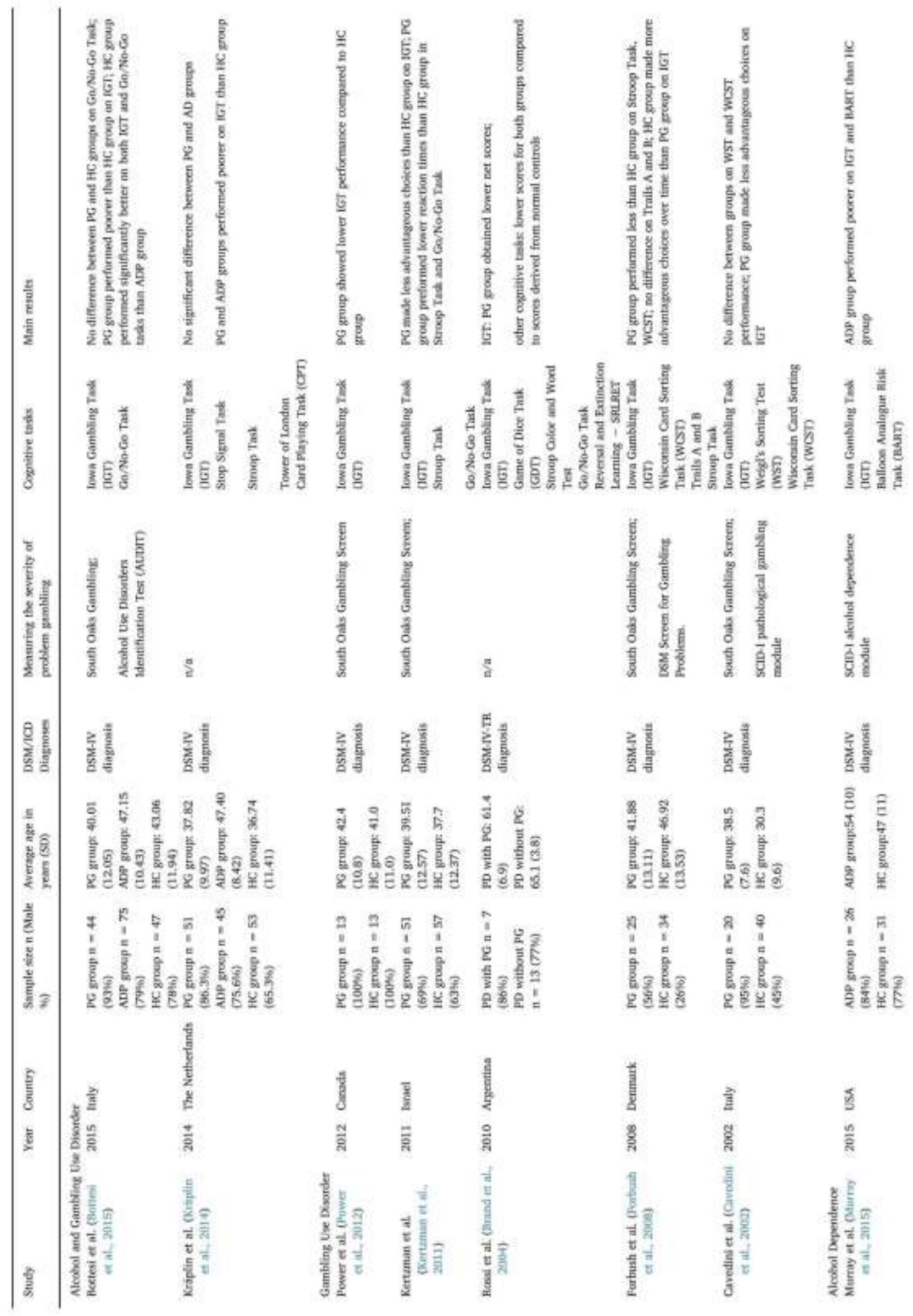




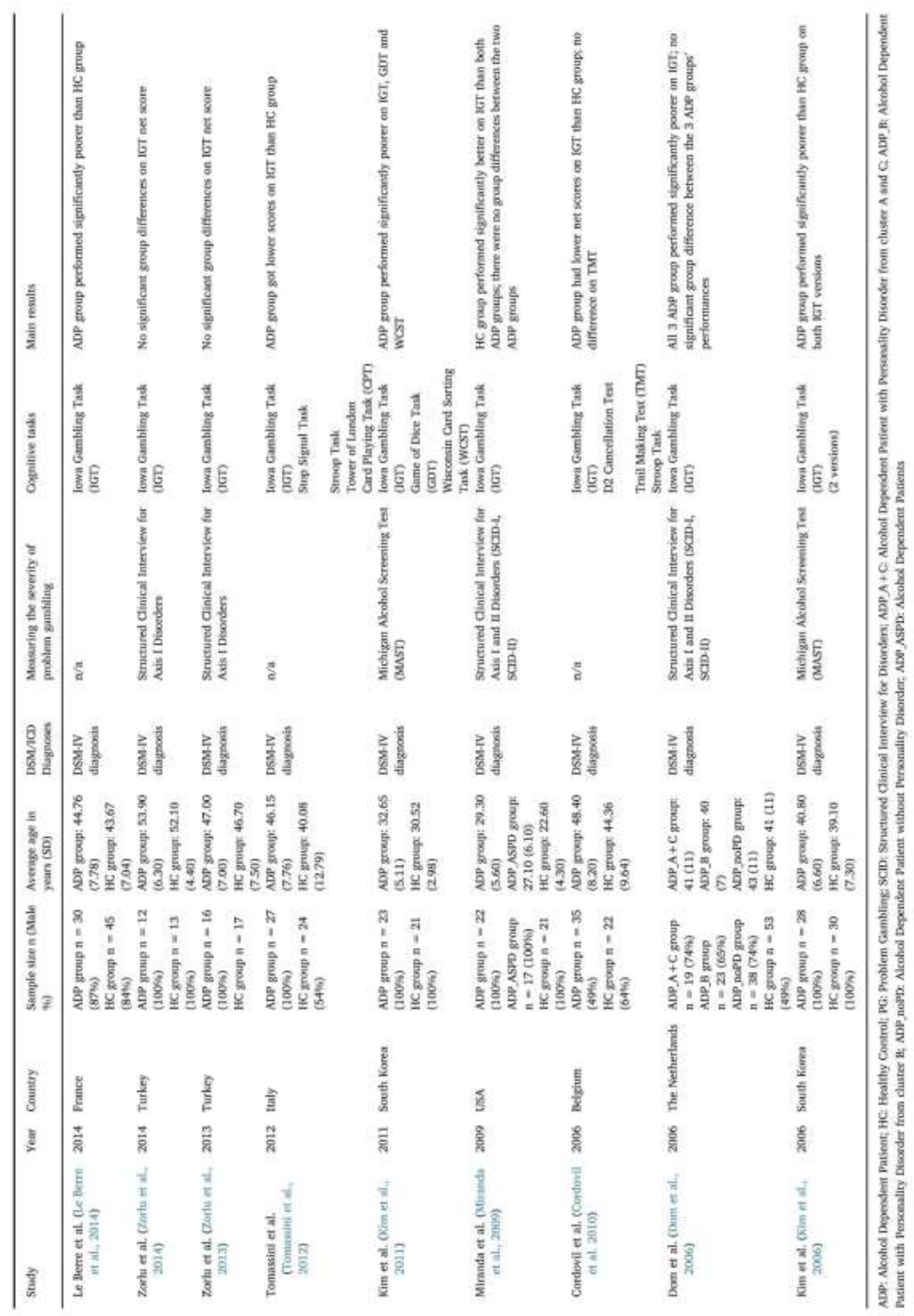


Annex 2: Exploratory correlation matrix of study variables

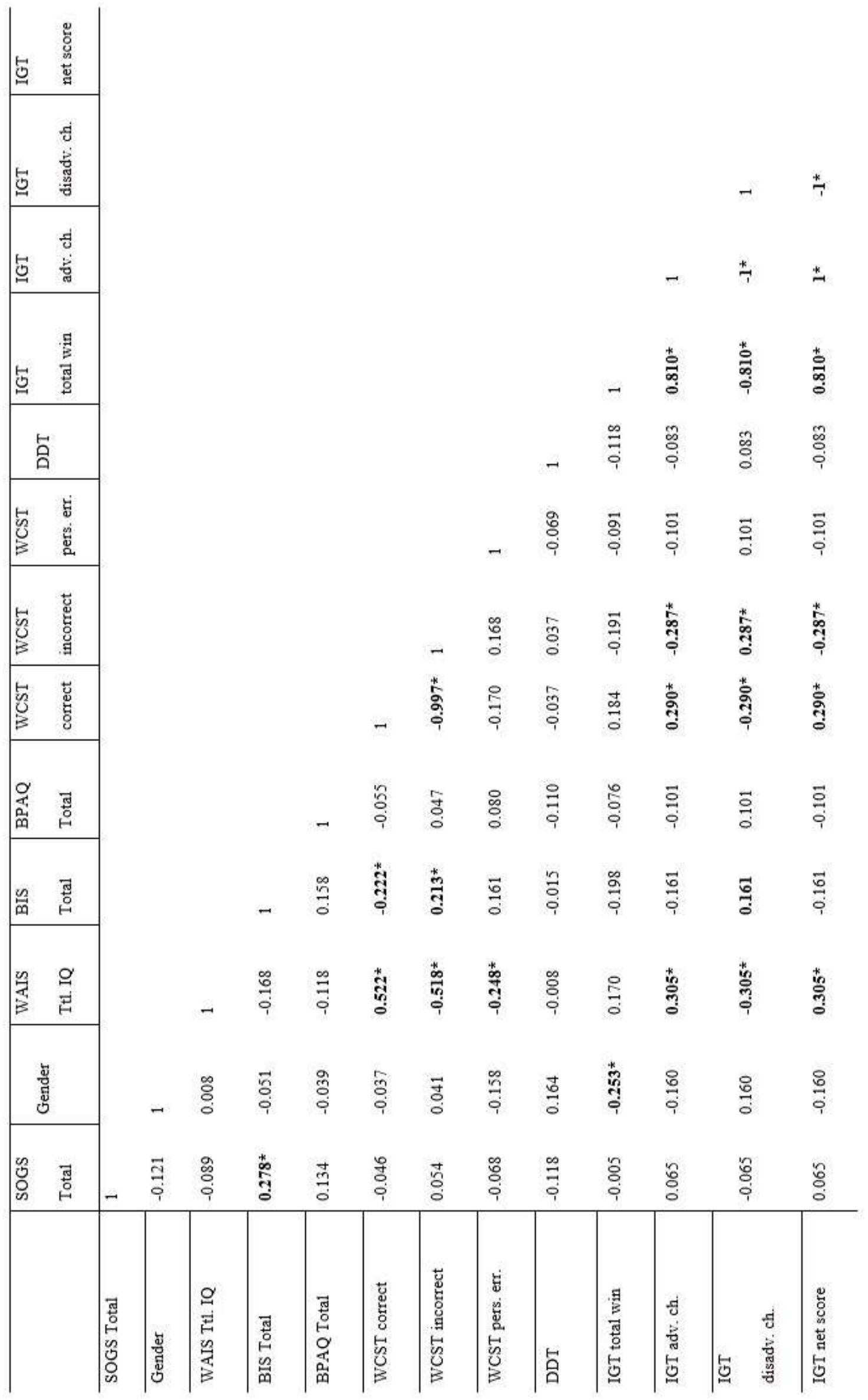


*correlation is significant at the 0.05 level

SOGS Total: South Oaks Gambling Scale total score; WAIS Ttl IQ: intelligence score measured with WAIS-IV; BIS Total: Barratt Impulsivity Scale total score; BPAQ Total: Buss-Perry Aggression Questionnaire total score; WCST correct: Wisconsin Card Sorting Task correct answers; WCST incorrect: Wisconsin Card Sorting Task incorrect answers; WCST pers. err.: Wisconsin Card Sorting Task perseverative errors; DDT: Delay Discounting Task; IGT total win: Iowa Gambling Task total amount of money won; IGT adv. ch.: Iowa Gambling Task total number of advantageous choices; IGT disadv. ch.: Iowa Gambling Task total number of disadvantageous choices; IGT net score: Iowa Gambling Task net score 
I. 


\section{Szerencsejáték-használati zavar és}

\section{alkoholhasználat-zavar - hasonlóságok és különbségek}

Andó Bálint¹, Kovács Ildikó1, Janka Zoltán¹, Demetrovics Zsolt²

1 SZTE ÁOK Pszichiátriai Klinika, Szeged

2 Eötvös Loránd Tudományegyetem, Pszichológia Intézet

Összefoglalás: A szerencsejáték-használati zavar lassan három évtizede szerepel a Mentális Zavarok Diagnosztikai és Statisztikai Kézikönyvében (DSM), és ez idő alatt diagnosztikai kritériumrendszere jelentös változáson ment keresztül. A DSM legújabb, ötödik kiadásában a szerencsejáték-használati zavar az Impulzuskontroll-zavarok közül az Addiktológiai zavarok közé került, felismerve és kinyilvánítva ezzel azt, hogy a szerencsejáték-használati zavar hasonló jellegzetességeket mutat, mint a szerhasználati addikciók. Jelen összefoglaló tanulmány célja ezen átsorolás indokainak feltárása, valamint a szerencsejáték-használati zavar és az alkoholhasználat-zavar közötti hasonlóságok feltérképezése tünettani, etiológiai és epidemiológiai szempontok mentén.

Kulcsszavak: alkoholhasználat-zavar; szerencsejáték-használati zavar; tünettan; komorbiditás; etiológia; kezelés

Summary: Gambling disorder has been listed in the Diagnostic and Statistical Manual of Mental Disorders (DSM) for more than three decades. During this time, its diagnostic set of criteria has gone through significant changes. In the DSM-5, gambling disorder has been moved from Disruptive, Impulse-Control and Conduct Disorders to SubstanceRelated and Addictive Disorders, which acknowledges and expresses that gambling disorder has similar features compared to substance related disorders. The aim of the present review is to reveal the reasons behind this category replacement, and to examine the similarities between gambling disorder and alcohol dependence from the perspectives of symptomatology, etiology and epidemiology.

Keywords: alcohol use disorder; gambling disorder; symptomatology; comorbidity; etiology; treatment

\section{Bevezetés}

Az új neurológiai, neurobiológiai, genetikai, viselkedéstudományi, epidemiológiai és egyéb tudományterületeken végzett vizsgálatok nagymértékben alakítják és pontosítják a mentális és viselkedési zavarokról alkotott tudásunkat, $\mathrm{s}$ ez képezi a DSM (Diagnostic and Statistical Manual of Mental Disorders, Mentális Zavarok Diagnosztikai és Statisztikai Kézikönyve) (1), folyamatos fejlesztésének, módosításainak hátterét. A 2013-ban megjelent DSM-5 a korábbi kiadáshoz (DSM-IV) képest számos változást hozott, azonban jelen áttekintés a szerencsejáték-használati zavar diagnosztikai jellegzetességében bekövetkezett változásokra fókuszál (2).

Az, hogy váltás történt a diagnosztikus kategóriákon belül - a szerencsejáték-használati zavar az impulzuskontroll-zavarok közül az addikto- lógiai zavarok közé került - arra utal, hogy a kutatások egy irányba mutatnak, miszerint a szerencsejáték-függőség hasonló jellegzetességeket mutat, mint a szerhasználati addikciók (3). Epidemiológiai, etiológiai, szimptomatológiai szempontokat figyelembe véve az elmúlt évtized kutatásai egyértelműen azt jelzik, hogy a szerencsejáték-használati zavar (korábban, a DSM-IV terminológiájában kóros játékszenvedély) átfedést mutat a kémiai addikciókkal, különös tekintettel az alkoholhasználat-zavarral. Jelen áttekintés e két zavar közötti kapcsolatot vizsgálja. Ennek során az alkoholproblémák diagnosztikus kritériumait összevetjük a szerencsejátékhasználati zavar (korábbi terminológia szerint patológiás/kóros szerencsejáték) diagnosztikus kritériumaival, mivel a vizsgálatok azt mutatják, hogy a „pszichoaktív szerek használatával kapcsolatos zavarok” (DSM-IV) közül ezzel mu- 
tat a legnagyobb komorbiditást $(2,4)$. Megkísérlünk továbbá választ találni arra, hogy mi lehet az oka a két zavar közötti magas komorbiditásnak, illetve, hogy a kutatások mennyiben támasztják alá a szerencsejáték-használati zavar addiktológiai zavarként történő értelmezését.

\section{A Szerencsejáték-használati zavar alakulása a DSM rendszerében}

A kóros játékszenvedély első alkalommal az 1980-ban kiadott DSM-III-ban jelent meg önálló betegségként az impulzuskontroll-zavarok között. A DSM következő, negyedik kiadásában a kóros játékszenvedély tíz diagnosztikus kritériumát határozták meg, amelyekből legalább ötnek kellett teljesülnie a diagnózis felállításához. A zavar továbbra is az impulzuskontrollzavarok között maradt. A DSM-IV revízióját követően a DSM-5-ben a korábban kizárólag kémiai addikciókat tartalmazó csoport megnyílt az egyéb függőségek előtt is, és elsőként (és egyelőre egyetlenként) a szerencsejáték-függőség került be az addiktológiai zavarok közé. Korábban felmerült, hogy az internetfüggőség vagy videojáték-függőség is ebbe a csoportba kerüljön, végül azonban az internetes játék zavar (internet gaming disorder) csupán a DSM mellékletében kapott helyet, önálló diagnosztizálható zavarként egyelöre nem jelenik meg (5). A névváltoztatás - szerencsejáték-használat zavara (gambling disorder) - szükségességének indoklásában szerepet játszik a szociális stigma csökkentésének szándéka, de az is, hogy jobban kifejeződjön a jelenség spektrum jellege, amely a szociális-rekreációs (adott esetben problémamentes) játéktól a problémás - addiktív - viselkedésig terjed. De nemcsak az elnevezésben, hanem a kritériumrendszerben is történtek változások. A DSM-5 diagnosztikus kritériumai közé így nem került be az illegális aktivitásra vonatkozó tétel („Illegális cselekményeket, mint hamisítást, csalást, lopást vagy sikkasztást követ el, hogy finanszírozza szerencsejátékát”). Az indoklása szerint ez a kritérium nem nyújt segítséget a szerencsejáték-használati zavar differenciáldiagnosztikájában, azaz ennek a kritériumnak a kivétele nem befolyásolja érdemben a szerencsejáték-zavar prevalenciaértékét $(2,4,6)$.

A szerhasználati diagnózisokhoz hasonlóan a szerencsejáték-használati zavar is dimenzionális szemléletű lett, azaz különböző súlyosságú diagnózis állítható fel (ld. a tünettannal foglalkozó fejezet). A DSM-5 munkacsoport javaslata alapján a pontosabb diagnózis felállításhoz csökkenteni kellett a küszöbszintet, azaz legalább négy kritérium teljesülése esetén állítható fel a diagnózis $(2,4)$.

\section{Alkoholhasználat-zavar és a szerencsejáték-használati zavar: tünettani elemzés}

A DSM-5 a „Szerrel összefüggő és egyéb addiktív zavarok" között kezeli mind az alkoholhasználati, mind a szerencsejáték-használati zavart. A kritériumok összehasonlítása az 1. táblázaton látható.

Megfigyelhető, hogy a szerencsejáték-használati zavar kritériumai jelentős átfedést mutatnak a szerfüggőségek kritériumaival (1. táblázat). Fontos hangsúlyozni, hogy azokban az esetekben, ahol a kritériumok nem feleltethetők meg egymásnak egy az egyben, tüneti szinten ott is jelen van a kölcsönösség. Így bár az időráfordítás vagy a sóvárgás kritériuma explicit módon nem jelenik meg a szerencsejáték-zavar esetében, ettől még ezek a jellemzők a tüneti kép szerves részét képezik. A munkahelyi teljesítmény, egzisztenciával és az interperszonális kapcsolatok terén tapasztalt hátrányok mellett empirikus vizsgálatokban igazolták, hogy a szerencsejáték-használati zavarral küzdők esetében sóvárgás (7), megvonási tünetek (8), tolerancia (9) és gyakori visszaesés (10) is tapasztalható. Ezen dimenziók egyértelműen megjelennek az alkoholhasználat-zavar esetében is.

Ahogy az a tünetek összegzéséből is kitűnik (2. táblázat), a zavar közös klinikai jellemzőket mutat, ilyenek például a kontrollvesztés, a sóvárgás vagy a magasabb szintű impulzivitás. Szintén közös vonása a két zavarnak, hogy mindkettő esetében annak ellenére folytatják a 
Szerencsejáték-használati zavar és alkoholhasználat-zavar - hasonlóságok és különbségek

\section{1. táblázat}

Az alkoholhasználat zavara és a szerencsejáték-használati zavar diagnosztikus kritériumának összehasonlítása (a kritériumok után a DSM-5 szerinti számozást jelöltük)

\section{Alkoholhasználat-zavar}

Szerencsejáték-használati zavar

A szándékoltnál nagyobb mennyiség vagy

hosszabb időn át tartó alkoholfogyasztás (1)

Tartós vágy vagy sikertelen próbálkozások az alkohol- Ismételt sikertelen próbálkozások a szerencsejáték

használat csökkentésére, abbahagyására (2)

kontrollálására, abbahagyására (3)

Jelentős mennyiségű időráfordítás az alkohollal

kapcsolatos tevékenységekre (3)

Sóvárgás (4)

A fó szerepkötelezettségek teljesítésének kudarca (5)

Fontos kapcsolatot, munkát, tanulási vagy

karrierlehetőséget ad fel a szerencsejáték miatt (8)

Folyamatos használat a nyilvánvaló interperszonális

Fontos kapcsolatot, munkát, tanulási vagy

és társas problémák ellenére (6)

A tevékenységek feladása az alkohol miatt (7)

karrierlehetőséget ad fel a szerencsejáték miatt (8)

Fontos kapcsolatot, munkát, tanulási vagy

karrierlehetőséget ad fel a szerencsejáték miatt (8)

Alkoholhasználat kockázatos helyzetekben (8)

Folyamatos használat a nyilvánvaló testi és lelki

problémák ellenére (9)

\begin{tabular}{ll}
\hline Tolerancia (10) & Egyre nagyobb pénzbeli tétek (1) \\
\hline Megvonás (11) & $\begin{array}{l}\text { A szerencsejáték tevékenység csökkentésekor } \\
\text { ingerlékenység vagy nyugtalanság (2) }\end{array}$ \\
\hline & A szerencsejátékkal kapcsolatos gondolati lekötöttség (4) \\
\hline & $\begin{array}{l}\text { Gyakran játszik, ha rosszul érzi magát } \\
\text { (búntudat, szorongás, depresszió) (5) }\end{array}$ \\
\hline A veszteség üldözése (6) \\
\hline $\begin{array}{l}\text { Hazudik a szerencsejáték mértékének } \\
\text { elkendőzése érdekében (7) }\end{array}$ \\
\hline Másokra támaszkodik a szerencsejáték miatt elóállt \\
kilátástalan pénzügyi helyzet megoldására (9)
\end{tabular}

Megjegyzés: Alkoholhasználat-zavar esetében enyhe zavar 2-3 tünet esetén, mérsékelten súlyos zavar 4-5 tünet esetén, és súlyos zavar 6 vagy több tünet esetén. Szerencsejáték-használati zavar esetében enyhe zavar 4-5 tünet esetén, mérsékelten súlyos zavar 6-7 tünet esetén, és súlyos zavar 8-9 tünet esetén.

\section{2. táblázat}

Alkoholhasználat-zavar és szerencsejáték-használati zavar hasonló jellegzetességei

Alkoholhasználat-zavar

Szerencsejáték-használati zavar

\begin{tabular}{cc} 
Alkoholhasználat-zavar & Szerencsejáték-használati zavar \\
\hline tolerancia kialakulása \\
\hline kontrollvesztés \\
\hline sóvárgás \\
\hline megvonási tünetek kialakulása \\
\hline munkahelyi/egzisztenciális hátrányok \\
\hline magas relapszuskockázat \\
\hline megemelkedett impulzivitás \\
\hline gátlófunkciók zavara \\
\hline magas komorbiditás mind serdülő-, mind felnőttkorban \\
kezelésben történó alacsony részvételi arány
\end{tabular}


szerencsejátékot/alkoholfogyasztást, hogy az káros az egészségükre, az anyagi helyzetükre és az interperszonális kapcsolataikra nézve, valamint hasonló aspektus a két függőségben, hogy mindkettő esetében megfigyelhetőek a „használat" csökkentésére irányuló sikertelen kísérletek.

Mindkét jelenség magyarázható továbbá az impulzivitással, illetve a gátláskontroll deficitjével, abban az esetben, amikor az azonnali pozitív megerősítés kerül előtérbe és válik a viselkedés abszolút meghatározójává (11).

A sóvárgás tekintetében is megfigyelhetőek hasonlóságok a két zavar esetében. Mindkét esetben megfigyelhető a sóvárgás jelensége, amelyet úgy határozhatunk meg, mint egy erős, kifejezett vágy a szerhasználatra/szerencsejátékra, vagy egy olyan, szerrel/játékkal kapcsolatos pozitív jutalmazó emlék, amely felülírja a negatív tapasztalatokat. A két zavarral összefüggő sóvárgás esetében azonban kiemelkedőek a különbségek, és figyelembe kell venni az érzelmi állapotot: szerencsejáték-használati zavar esetében fordított kapcsolatot állapítottak meg a pozitív érzelmek és a játék iránti sóvárgás között, amelyből arra következtettek, hogy a szerencsejáték egyfajta megküzdési eszköz a pozitív érzelmek/tapasztalatok hiányával (7). Egy másik tanulmányban az alkoholhasználat-zavar és a szerencsejáték-használati zavar esetében megfigyelt sóvárgás jellegzetességeit vetették össze. Eltérést figyeltek meg abban a tekintetben, hogy a szerencsejáték-használat kapcsán tapasztalt sóvárgás jobban kötődik a környezeti tényezőkhöz, míg az alkoholhasználat-zavar esetében inkább a fellépő negatív állapothoz kapcsolódik, amely az alkoholhasználat, mint a valóság előli menekülés elméletét erősíti meg (12).

Az alkoholdependenciához hasonlóan, a szerencsejáték-használati zavarban is megfigyelhetők megvonásos tünetek. A szerencsejátékfüggőség terápiás kezelése során a kezelésben résztvevők 30-40\%-ánál erős viselkedés- és hangulatzavarokat tapasztaltak. Ezek minősége és milyensége erős hasonlóságot mutatott az alkoholmegvonás során tapasztalt megvonási tünetekkel, amelyek a következők: alacsony hangu- lati fekvés, irritábilitás, motoros agitáció, tremor, a koncentráció és a figyelem fókuszálásának zavara (8).

A szerencsejáték-használati zavarban a tolerancia kialakulását is dokumentálták, ugyanúgy, mint az alkoholhasználat-zavarban. Griffiths vizsgálatában arra hívta fel a figyelmet, hogy az időszakos és a rendszeres szerencsejátékosokat összehasonlítva látható, hogy a szerencsejátékfüggők fiziológiai szinten is adaptálódtak a szerencsejátékhoz, így ahhoz, hogy ugyanazt a pszichológiai, fiziológiai állapotot érjék el, jelentősen növelniük kellett a játékkal töltött időt. Ez a jelenség párhuzamba állítható az alkoholfüggőségben kialakuló szertoleranciával (9).

A szerencsejáték-zavarban, a pszichoaktív szerekkel kapcsolatos függőségekhez hasonlóan jellemzőek a visszaesések. Vizsgálatok rávilágítottak, hogy hasonló pszichológiai, biológiai és társas/környezeti faktorok - például: hasonló személyiségjegyek (neuroticizmus és extraverzió), kognitív torzítások (kontrollérzet illúziója a használat felett), megküzdési mechanizmusok (maladaptív megküzdési módok alkalmazása stressz-szituációkban) és személyiségvonások (magasabb impulzivitás, magasabb szenzoros élménykeresés) - játszanak szerepet mindkét zavar esetében a relapszus kialakulásában (10).

Jelenpreferencia, impulzivitás, és a gátlásfunkció zavara jellemzi a szerencsejáték-használati zavar és az alkoholhasználat-zavar klinikai képét (12-14) egyaránt. A két zavar együttes fennállása esetén azokat, akiknél mindkét zavar jelen volt, nagyobb mértékű kockázatvállalás jellemezte (15), továbbá az alkoholhasználatzavar és a szerencsejáték-használati zavar külön-külön is érintett: döntéshozatali deficit kimutatható mindkettőnél (16).

Nemcsak klinikai, hanem szubklinikai mintán is igazolták az impulzivitás és a szerencsejáték, valamint az alkoholhasználat összefüggéseit. Mind a szerhasználó, mind a szerencsejátékos csoport magasabb mért impulzivitást mutatott kontrollcsoporthoz viszonyítva, továbbá azon személyek, akiknél alkoholhasználatot és szerencsejátékot is megállapítottak, még magasabb impulzivitást mutattak (17). 


\section{Közös etiológiai faktorok}

A szerhasználati problémák esetében a pszichoaktív szer (jelen esetben az alkohol) okozta krónikus neurobiológiai hatás miatt fokozatosan csökken a gátlás képessége, amit a prefrontális kéreg mediál (18). Ez a lehetséges egyik út az emelkedett impulzivitás hátterében, azonban egyre több tanulmány szerint a gátlásfunkció deficitje már korábban fennállt a szerhasználat előtt és vulnerabilitási faktornak tekinthető a kialakulásra nézve, mediálja a rekreációs használatból a dependenciába való átmenetet. E kettő egy lehetséges értelmezése, hogy egyszerre jelenik meg tünettanilag is, illetve az etiológiai tényezők között is az impulzivitás, azaz, hogy a szerfüggő személyek eleve impulzívabb személyiségek, és ezt fokozza a szer hatása (11).

Szerhasználat szempontjából három rizikócsoportot lehet elkülöníteni: (a) serdülők fokozottan ki vannak téve a szerhasználat veszélyeinek; (b) olyan klinikai csoportok, amelyek externalizáló viselkedészavarokat mutatnak (pl.: figyelemhiányos hiperaktivitás-zavar és magatartászavar) és (c) szerfüggőséggel diagnosztizált szülők gyermekei genetikai és környezeti faktorokból eredően fokozott veszélynek vannak kitéve (11). Már serdülőkorban együtt jár a szerencsejáték-használati zavar és alkoholhasználat-zavar (19), valamint felnőttkorban is nagy a komorbiditás a kettő között, ezért feltételezhető egy közös etiológiai háttér a két zavar hátterében. Ikervizsgálatokban igazolták a szerencsejáték-használati zavar és az alkoholhasználat-zavar közös genetikai prediszpozícióját. Olyan ikerpárok esetében, akiknél a DSM-IV alapján kóros játékszenvedélyt diagnosztizáltak, nyolcszor nagyobb eséllyel szerepelt kórtörténetükben az alkoholhasználat zavara, összehasonlítva azokkal az ikerpárokkal, akiknél a zavart nem diagnosztizálták. Mind monozigóta, mind dizigóta ikerpárok esetében már szubklinikai szerencsejáték-használati zavar fennállása esetén is jelentősen magasabb a komorbid alkoholhasználat-zavar fennállásának esélye: 50,4\% monozigóta és 44,3\% dizigóta ikerpárok esetében, míg a nem szerencsejátékos ikerpárok esetében $33,5 \%$ és $35 \%$ az alkoholhasználat-za- var fennállásának esélye (20). Továbbá számos faktort azonosítottak, amely fennállása mellett jelentősen megnő mind az alkoholhasználat-zavar, mind pedig a szerencsejáték-zavar kialakulásának az esélye. Ilyen tényező például a gyermekkori maladaptív bánásmód, vagy pedig a családi halmozódás (alkoholfüggő vagy szerencsejátékos szülők gyermekei nagyobb százalékban válnak maguk is szer-/játékfüggővé) (21).

Az addikcióknak, beleértve a szerencsejátékhasználati zavart, neuropszichológiai szempontból közös vulnerabilitási faktorai vannak. Számos vizsgálat összegzése alapján a szerencsejáték-használati zavarral diagnosztizált személyek önbevallás alapján mért magasabb impulzivitásról számoltak be, valamint esetükben a különböző neuropszichológiai tesztek alapján alacsonyabb gátláskontrollt figyeltek meg. E vizsgálatok alapján az a feltételezés látszik alátámasztottnak, hogy az impulzuskontroll zavara megelőzi a függőség kialakulását, így a különböző addikciók kialakulásában vulnerabilitási faktorként azonosítható (11). Agyi képalkotó eljárásokat alkalmazó és neurokémiai vizsgálatokban azt is kimutatták továbbá, hogy a szerfüggőségek esetében egyazon agyi jutalmazó rendszer hasonlóan aktiválódik, mint a szerencsejáték-zavar esetében (nucleus accumbens „elárasztása” dopaminnal, hippocampus és amygdala pedig az erős örömérzet emlékének rögzüléséért és a hasonló ingerre kondicionált válasz megalkotásában játszik szerepet) $(14,22)$.

\section{Komorbiditás}

Epidemiológiai szempontból is hasonlóságok mutatkoznak a szerencsejáték-használati zavar és az alkoholhasználat-zavar között. A National Epidemiologic Survey on Alcohol and Related Conditions (NESARC Study) (22) és a National Comorbidity Survey Replication (NCS-R) (23) pszichiátriai epidemiológiai vizsgálatok szerint a problémás szerencsejátékkal az egyik leggyakrabban együtt járó probléma a rendellenes alkoholfogyasztás. Amerikai normál populációs felmérés eredményei alapján a felnőttek közel 90\%-a próbált már ki valamilyen szerencsejáté- 
kot, de közülük csak kicsivel több, mint 10\%-uk nevezhető problémás szerencsejátékosnak, míg ennél is kevesebb esetében diagnosztizálható a tényleges klinikai szerencsejáték-zavar. Ezzel szemben szerfüggő felnőttek esetében a szerencsejáték-zavar prevalenciája 29\% (ehhez képest normál populáció esetében ez az arány 5\%) (24, 25). A patológiás szerencsejáték élettartam-prevalencája $0,42 \%$, valamint a patológiás szerencsejátékosok közel háromnegyedénél $(73,2 \%)$ valamilyen komorbid szerfüggőséget is diagnosztizáltak, 60,4\%-uk nikotinfüggőségben, 49,6\%-uk hangulatzavarban, 41,3\%-uk pedig szorongásos zavarban szenvedett, míg 60,8\%uknál pedig valamilyen személyiségzavart diagnosztizáltak (23).

\section{Egyéb pszichiátriai zavarok előfordulása}

A szerencsejáték-használati zavar és az alkoholhasználat-zavar esetében is hasonló komorbid pszichiátriai zavarok meglétét igazolták. Mindkét függőség nagymértékű együtt járást mutat a hangulatzavar-spektrum eltéréseivel, a szorongásos zavarokkal, a szuicídiummal és egyes személyiségzavarokkal. Csakúgy, mint alkoholfüggőségnél, szerencsejáték-használati zavar esetében is emelkedettebb szintet mutatnak a személyiségzavarok, valamint a kettő együttes fennállása jelentősen növeli a szuicídium kockázatát (26). Egy nagymintás vizsgálat alapján azt is közölték, hogy a patológiás szerencsejátékosok több mint 79,1\%-ánál kimutatható valamilyen pszichiátriai zavar, amelyek közül a különböző szerfüggőségek, hangulat- és szorongásos zavarok, valamint a szuicídium mutatta a legnagyobb mértékủ összefüggést (27). További, a témában végzett metaanalízis is ezen komorbid zavarok meglétét támasztotta alá: számos tanulmány eredményeit összesítve a szerencsejáték-használati zavarral egyéb szerhasználati zavarok 57,5\%-ban, hangulatzavarok 37,9\%ban, míg szorongásos zavarok 37,4\%-ban járnak együtt (28).

\section{Hasonlóságok a prognózis tekintetében}

Mind szerencsejáték-használati zavar, mind pedig alkoholhasználat-zavar esetében alacsony a kezelésben való részvételre való törekvés, csakúgy mint maga a terápiás kezelésekben történő részvétel is $(19,29)$. Szerencsejáték-használati zavarral diagnosztizált személyek alig 10\%-a keres kezelést. A kezelésben történő részvételi arány még alacsonyabb (7\% körüli) olyan személyek esetében, akik ugyan problémás szerencsejátékosok, de a zavar náluk nem diagnosztizálható. A kezelésben történő részvételi arányok alkoholbetegek esetében is hasonlóan alakulnak, a függőséggel diagnosztizált betegek alig 12\%-a keres professzionális segítséget (29).

A témában végzett vizsgálatok abba az irányba mutatnak, hogy a szerencsejáték-használati és az alkoholhasználat-zavar együttes fennállása esetében ezek kölcsönhatásai befolyásolhatják a terápiás kimenetelt. Egy vizsgálatban olyan szerencsejáték-függők alkoholfogyasztási jellemzőit tárták fel, akik szerencsejáték-függőségükre kezelésben részesültek. Megfigyelhető volt, hogy bár a kezelés megkezdésével párhuzamosan alkoholfogyasztásuk mértéke is egy időre csökkenő tendenciát mutatott, de a kezelésben eltöltött idő során ez a csökkenő tendencia elmúlt, és a minta $31 \%$-a excesszív, problémás alkoholhasználatot mutatott (21). Ennek tükrében egy kutatásban arra kerestek választ, hogy az előzetesen fennálló alkoholhasználatzavar befolyásolja-e a szerencsejáték-viselkedést és a kezelés hatékonyságát. Az derült ki, hogy a súlyosabb alkoholfüggőség súlyosabb szerencsejáték-zavarral mutatott erős pozitív kapcsolatot, valamint a kettő együttes fennállása mellett egyéb pszichés tünetek is erőteljesen jelentkeztek (30).

\section{Konklúzió}

A mentális betegségek diagnosztikai és statisztikai kézikönyvének legújabb, ötödik kiadásában a szerencsejáték-használati zavar az impulzuskontroll-zavarok közül átkerült az addiktológiai zavarok közé. Jelen áttekintő tanulmány 
középpontjában azon hasonlóságokat vettük számba, amelyek az átsorolást indokolták (2). Látható, hogy a két betegség tüneti hasonlóságokat mutat azokban a kardinális pontokban, amelyek az addikció alapját képezik. Mindkét zavar esetében megjelenik a megemelkedett tolerancia (9), a kontrollvesztés, a szerencsejáték, illetve az alkohol iránti sóvárgás (7), és az addikciótól történő tartózkodás esetén megvonási tünetek is jelentkeznek (8). Közös jellemző továbbá a jelenpreferencia, a gátlófunkciók zavara (11), továbbá az impulzivitás - mint vulnerabilitási faktor (12-14) - a szerencsejáték-használati zavarban és alkoholhasználat-zavarban is ugyanúgy megjelenik, mint a többi szerhasználat-zavarban. A számos közös jellegzetesség hátterében közös pszichológiai, etiológiai és környezeti faktorokat azonosítottak (20, 21).

\section{I rod a I o m}

1. AMERICAN PSYCHIATRIC ASSOCIATION: Diagnostic and Statistical Manual of Mental Disorders (5th ed.). Washington, DC: Author; 2013.

2. REILLY C, SMITH N:

The Evolving Definition of Pathological Gambling in the DSM-5. National Center of Responsible Gaming; 2015.

3. DEMETROVICS Z, GRIFFITHS MD: Behavioral addictions: Past, present and future. J Behav Addict 2012, 1(1): 1-2.

4. DENIS C, FATSÉAS M, AURIACOMBE M: Analyses related to the development of DSM-5 criteria for substance use related disorders: 3 . An assessment of Pathological Gambling criteria. Drug Alcohol Dep 2012, 122(1-2): 22-27.

5. GRIFFITHS MD, KING DL, DEMETROVICS Z: DSM-5 internet gaming disorder needs a unified approach to assessment. Neuropsychiatry 2014, 4(1): 1-4.

6. STRONG DR, KAHLER CW: Evaluation of the continuum of gambling problems using the DSM-IV. Addiction 2007, 102(5): 713-721.

7. TAVARES H, ZILBERMAN ML, HODGINS DC, EL-GUEBALY N:

Comparison of craving between pathological gamblers and alcoholics. Alcohol Clin Exp Res 2005, 29(8): 1427-1431.

8. WRAY I, DICKERSON MG:

Cessation of high frequency gambling and 'withdrawal' symptoms. Brit J Addict 1981, 76(4): 401-415.

9. GRIFFITHS M:

Tolerance in gambling: an objective measure using the psychophysiological analysis of male fruit machine gamblers. Addict Behav 1993 18(3): 365-372.

10. LEDGERWOOD DM, PETRY NM: What do we know about relapse in pathological gambling?

Clin Psychol Rev 2006, 26(2): 216-228.

11. VERDEJO-GARCIA A, LAWRENCE AJ, CLARK L: Impulsivity as a vulnerability marker for substance-use disorders: Review of findings from high-risk research, problem gamblers and genetic association studies. Neurosci Biobehav Rev 2008, 32(4):777-810.
12. DE CASTRO V, FONG T, ROSENTHAL RJ, TAVARES $\mathrm{H}$ :

A comparison of craving and emotional states between pathological gamblers and alcoholics. Addict Behav 2007, 32(8):1555-1564.

13. LORAINS FK, STOUT JC, BRADSHAW JL, DOWLING NA, ENTICOTT PG:

Self-reported impulsivity and inhibitory control in problem gamblers. J Clin Exp Neuropsychology 2014, 36(2):144-157.

14. BLUM K, FEBO M, MCLAUGHLIN T CRONJÉ FJ, HAN D, GOLD MS: Hatching the behavioral addiction egg: Reward Deficiency Solution System (RDSS) ${ }^{\mathrm{TM}}$ as a function of dopaminergic neurogenetics and brain functional connectivity linking all addictions under a common rubric. J Behav Addict 2014, 3(3): 149-156.

15. LEDGERWOOD DM, ALESSI SA, PHOENIX N, PETRY NM:

Behavioral assessment of impulsivity in pathological gamblers with and without substance use disorder histories versus healthy controls. Drug Alcohol Depend 2009, 105: 89-96.

16. LAWRENCE A J, LUTY J, BOGDAN NA SAHAKIAN BJ, CLARK L:

Problem gamblers share deficits in impulsive decision-making with alcohol-dependent individuals. Addiction 2009, 104: 1006-1015.

17. PETRY NM:

Substance abuse, pathological gambling, and impulsiveness. Drug Alcohol Depend 2001, 63(1): 29-38.

18. BECHARA A:

Risky business: Emotion, decision-making, and addiction. J Gambl Stud 2003, 19: 23-51.

19. HOLDEN C:

Behavioral addictions debut in proposed DSM-V. Science 2010, 327(5968): 935.

20. SLUTSKE WS, ELLINGSON JM, RICHMOND-RAKERD LS, ZHU G, MARTIN NG Shared genetic vulnerability for disordered gambling and alcohol use disorder in men and women: evidence from a national community-based australian twin study. Twin Res Hum Genet 2013, 16(2): 525-534.

21. RASH CJ, WEINSTOCK J, PETRY NM: Drinking patterns of pathological gamblers before, during, and after gambling treatment, Psychol Addict Behav 2011, 25(4): 664-674.

22. CAETANO R:

The National Epidemiologic Survey on Alcohol and Related Conditions (NESARC) - a huge resource for data and research findings. Addiction 2014, 110(3), 378-380.

23. KESSLER RC, BERGLUND P, CHIU WT, DEMLER O, HEERING S, HIRIPI E, ÉS MTSAI: The US National Comorbidity Survey Replication (NCS-R): design and field procedures. Int J Method Psychiat Res 2004, 13(2): 69-92.

24. SHAFFER HJ, HALL MN:

Updating and refining prevalence estimates of disordered gambling behaviour in the United States and Canada. Can J Public Health 2001, 92(3): 168-172.

25. PETRY NM, STINSON FS, GRANT BF Co-morbidity of DSM-IV pathological gambling and other psychiatric disorders: results from the National Epidemiologic Survey on Alcohol and Related Conditions. J Clin Psychiatry 2005, 66: 564-574.

26. BISCHOF A, MEYER C, BISCHOF G, JOHN U, WURST FM, THON N ÉS MTSAI: Suicidal events among pathological gamblers: the role of comorbidity of axis I and axis II disorders. Psychiat Res 2015, 225(3), 413-419.

27. PARK S, CHO MJ, JEON HJ, LEE HW, BAE JN PARK JI ÉS MTSAI:

Prevalence, clinical correlations, comorbidities, and suicidal tendencies in pathological Korean gamblers: results from the Korean Epidemiologic Catchment Area Study. Soc Psychiat Epidemiol 2010, 45(6): 621-629.

28. LORAINS FK, COWLISHAW S, THOMAS SA: Prevalence of comorbid disorders in problem and pathological gambling: systematic review and meta-analysis of population surveys. Addiction 2011, 106(3): 490-498.

29. BRAUN B, LUDWIG M, SLECZKA P, BÜHRINGER G, KRAUS L: Gamblers seeking treatment: Who does and who doesn't? J Behav Addict 2014, 3(3): 189-198.

30. STINCHFIELD R, KUSHNER MG, WINTERS KC Alcohol use and prior substance abuse treatment in relation to gambling problem severity and gambling treatment outcome. J Gambl Stud 2005, 21(3): 273-297. 
II. 
Review

\title{
Decision making measured by the Iowa Gambling Task in alcohol use disorder and gambling disorder: a systematic review and meta-analysis
}

\author{
Ildikó Kovács ${ }^{\mathrm{a}, *}$, Mara J. Richman ${ }^{\mathrm{b}}$, Zoltán Janka ${ }^{\mathrm{a}}$, Aniko Maraz ${ }^{\mathrm{b}, 1}$, Bálint Andó ${ }^{\mathrm{a}, 1}$ \\ a Department of Psychiatry, Faculty of Medicine, University of Szeged, Kálvária Ave. 57, H-6725, Szeged, Hungary \\ b Institute of Psychology, Eötvös Loránd University, Izabella Str. 46, H-1064, Budapest, Hungary
}

\section{A R T I C L E I N F O}

\section{Keywords:}

Decision-making

Impairment

Iowa Gambling Task

Alcohol use disorder

Gambling disorder

Meta-analysis

\begin{abstract}
A B S T R A C T
Background and aims: Gambling disorder (GD) and alcohol use disorder (AD) have similar features, such as elevated impulsivity and decision-making deficits, which are directly linked to relapse and poor therapeutic outcomes. Our aim was to assess decision-making characteristics in GD and AD patients compared to healthy controls (HC) based on one of the most frequently used measures of decision-making: the Iowa Gambling Task (IGT).

Methods: In our systematic literature search of three databases, we identified 1198 empirical articles that mentioned decision-making deficits with the use of the IGT in patients diagnosed with either AD or GD. Possible effects were calculated using meta-analysis. In the end, 17 studies (including 1360 participants) were suitable for inclusion in the meta-analysis reporting data for 23 group contrasts.

Results: The random effects estimate indicated impaired IGT performance in both AD patients $(\mathrm{N}=500$; $\mathrm{d}=-0.581$, CI:-89.5 $<\delta<-26.6 \%)$ and an even greater deficit in GD patients $(\mathrm{N}=292 ; \mathrm{d}=-1.034$, CI:$156.1<\delta<50.7 \%)$ compared to HCs. Sampling variances were calculated for both AD $\left(v_{1}=0.0056\right)$ and GD groups $\left(v_{2}=0.0061\right)$, from which the $\mathrm{z}$-score was calculated $(\mathrm{z}=-21.0785 ; p<0.05)$, which indicates a statistically significant difference between AD and GD groups. No significant moderating effects of age, gender or education were found.

Conclusions: There is enough evidence to support that decision-making deficit associated with addictive disorders, and that the deficit is more expressed in gambling disorder than in alcohol use disorder. Impaired decision-making plays an important part in poor therapeutic outcomes, thus provides a promising opportunity for cognitive intervention.
\end{abstract}

\section{Introduction}

Gambling disorder (GD) is currently the only non-substance related addiction listed under "Substance-Related and Addictive Disorders" in the fifth edition of the Diagnostic and Statistical Manual of Mental Disorders (DSM) (American Psychiatric Association, 2013). Substantial empirical evidence has highlighted similarities and common features between GD and other substance related disorders, particularly alcohol use disorder (AD) (Petry et al., 2014). One of the similarities between $\mathrm{GD}$ and $\mathrm{AD}$ is cognitive impulsivity, which stems from maladaptive decision-making strategies, and what is generally considered to be a strong predictor of behaviour and treatment outcomes (Krishnan-Sarin et al., 2007; Moeller et al., 2001; Verdejo-García et al., 2007).

Recent etiological studies report that GD and AD are highly comorbid both in community (Cunningham-Williams et al., 1998; Petry et al., 2005; Welte et al., 2001) and treatment seeking groups (Feigelman et al., 1998; Stinchfield et al., 2005). One of the possible reasons behind this elevated comorbidity is the biological and phenomenological similarity between GD and AD. Studies demonstrated that GD and AD have mutual underlying genetic (Blanco et al., 2006; Slutske et al., 2010), epidemiological (Cunningham-Williams et al., 1998; Petry et al., 2005), and etiological (Kessler et al., 2005; Welte et al., 2001) factors. The two disorders share common symptomatology such as craving (de Castro et al., 2007), withdrawal symptoms and tolerance (Blaszczynski et al., 2008), frequent or multiple relapses (Ledgerwood and Petry, 2006), the use of inadequate coping mechanisms (Crocq, 2003), and/or failure in response inhibition (Lawrence et al., 2009a).

Besides biological and psychological factors, social context is also an important domain of gambling and drinking behaviour. There is

\footnotetext{
* Corresponding author.

E-mail address: kovacs.ildiko.1@med.u-szeged.hu (I. Kovács).

${ }^{1}$ The authors contributed equally to the manuscript.
} 
evidence that higher prevalence of problem gambling is closely linked to the availability and expansion of gambling venues, where alcohol is commercially available (Markham et al., 2012). Multiple studies also reported that both GD and AD show similar differences concerning gender, age and education. Gender ratios (male/female) for the prevalence rates in high frequency and high-volume drinking indicated that men drink on more days per week and consume more grams of ethanol per day than women in every age group (Wilsnack et al., 2009); same applies in GD, where women are also less likely to have gambling problems (odds ratio $=0.16$ ) (Stoltenberg et al., 2008). Younger age of onset was related to greater symptom severity and number of dependence episodes in both diseases. Those who began drinking before the age of 14 had higher risk of developing lifetime alcohol dependence (HR: 1.78; 95\% CI: 1.51-2.11) and were almost three times more likely to have experienced more than two dependence episodes at the same time of assessment (OR: 2.89; 95\% CI: 1.97-4.23) compared to those who started drinking after the age of 25 (Hingson et al., 2006). Similarly, younger age of onset was associated with greater symptom severity and more treatment dropout $(\mathrm{OR}=0.976$; 95\% CI: 0.954-0.998) (Jiménez-Murcia et al., 2010). The level of education and problem gambling/drinking and dependence show an inverse relationship, given that people without tertiary education are more prone to develop $\mathrm{AD}$ (estimated relative risk for people with 9-12 years of completed education is six-fold compared to those who obtained a college degree where the estimated relative risk is three-fold) and/or GD (those who left school before year 10 were 2.6 times more likely to develop problematic gambling compared to those who obtained an university degree) (Brunborg et al., 2016; Sproston et al., 2012). Moreover, GD and $\mathrm{AD}$ also share common neurobiological processes in the regards of underlying urges and reward sensitivity. Studies conducted in this field indicate that both diseases stem from similar underlying mechanisms.

Regarding such mechanisms, clinical and preclinical studies reported that this mechanism involves a specific brain system, the ventral tegmental area - nucleus accumbens - orbital frontal cortex circuit that processes incoming reward inputs (Blum et al., 1995; Gilpin and Koob, 2008; Potenza, 2013, 2001). Another process strongly linked to the reward and punishment system is the process of decision-making. Based on the extensive literature body on decision-making, impulsivity is frequently mentioned in connection with the weaknesses of decisionmaking (Franken et al., 2008; Morgan et al., 2006). Consequently, highly impulsive individuals tend to disregard the consequences of their decisions. Decision-making may be the key feature of understanding both GD and AD. Decision-making is considered to be a facet of impulsivity, which is a topic widely addressed throughout the scope of addictive disorders. Bechara (2005) described decision-making as a complex set of cognitive processes which allow individuals to select the most optimal course of action following reasoned consideration of existing alternatives. The measurement of decision-making in addictive disorders mainly focuses on the assessment of performance-based neurocognitive tasks often compared to other cognitive variables like executive functions or intelligence. People suffering from AD and/or GD show similar features in various decision-making tasks. Impaired inhibitory control was measured by the Stop Signal Reaction Time and the Stroop Color and Word Test, compared to HC group; the authors found no statistically significant difference between AD and GD patient groups in the aforementioned domains (Goudriaan et al., 2006). This similarity was also supported using the Cambridge Gamble Task, where GD and AD also exhibited impaired decision-making (Lawrence et al., 2009b).

One of the most frequently used and ecologically valid assessment tools for measuring decision-making is the Iowa Gambling Task (IGT), which is a computerized neuropsychological task in which participants are shown 4 virtual decks of cards (labelled A, B, C, and D) and are asked to choose 100 times from the decks. In each selection, they win or lose money with the deck they selected, and the goal is to win as much money as they can. With each selection, participants can either win, or win and lose at the same time; each deck differs from each other in the ratio of wins and losses. Decks labelled C and D are considered advantageous; they result in more monetary wins and fewer losses on the long run. This means that the participant is more likely to have gained money than to have lost (i.e., "You won $€ 100$, and You lost $€ 40$ ", making a profit of $€ 60$ on this single choice)". On the other hand, decks with label A or B are disadvantageous, and likely to result in loss (i.e., "You won $€ 40$, and You lost $€ 100$ ", making a loss of $€ 60$ on this single choice). Therefore the series of decision results in profit or loss over multiple choices by the end of the experimental task. Healthy persons are likely to learn the rule after 40-50 trials and choose from the profitable decks, but impulsive participants are likely to persevere with the loosing decks making a monetary loss by the end of the game (Bechara et al., 1994; Bechara et al., 1997). Participants are informed in the beginning of the task that some decks are more profitable than others. During the task they easily learn which decks are "good" and which are "bad" and make choices accordingly. The IGT net score is calculated by subtracting the total number of selections from disadvantageous decks $(\mathrm{A}+\mathrm{B})$ from the total number of selections from advantageous decks $(C+D)$. One of the main reasons for its popularity is that the IGT models real-life decision-making under laboratory circumstances (Bechara et al., 1997). Unlike self-reported questionnaires of impulsivity, which are prone to bias due to individual differences in self-reflection, the IGT has the potential to be used as a direct evaluation method of measuring impulsivity (Bechara et al., 1994; Bechara et al., 1997). For best performance on the IGT, participants have to abandon short-term advantageous choices (resulting in immediate high rewards) that turn out to be disadvantageous in the long run (higher losses/punishments). Instead, participants must prefer long-term advantageous choices, which result in lower immediate rewards but lower long-term losses as well, thus higher long-term gain.

People with GD and AD also tend to show impaired decision-making measured by the IGT. While there is significant empirical data concerning the decision-making processes of these disorders, the comparison of decision-making among patients with these two disorders is scarce (Goudriaan et al., 2005). It is reported that the two diseases have high comorbidity rates. Moreover, numerous empirical studies examine decision-making in AD and GD.

The elevated level of impulsivity is closely connected to the ability and willingness to take risks and make risky decisions in real-life situations. This affects everyday life behaviour in several ways; the severity of poor decision-making, the loss of ability to control temptation and the lack of willpower to resist substance use or gambling activity are closely connected to relapse and poorer therapeutic outcomes in addictive disorders (Franken et al., 2008; Lawrence et al., 2009a). This emphasizes the importance of dimensionality in the research and treatment of addictive disorders which is in line with official diagnostic trends (American Psychiatric Association, 2013). A comprehensive synthesis of existing knowledge about decision-making in GD and AD and the understanding of the existing differences could provide clinically relevant and important information regarding possible cognitive interventions. Also, it could point out directions for further detailed studies.

\subsection{Aims of the study}

Since the characteristics of decision-making and its relevance in the clinical pictures of AD and GD is of high importance, the main aim of this study is to systematically review empirical data concerning decision-making in patients diagnosed with GD or AD compared to healthy control (HC) groups. Moreover, this is the first meta-analysis to explore whether patients with $\mathrm{GD}$ and $\mathrm{AD}$ report similarities in the characteristics of decision-making using one of the most popular measures of cognitive impulsivity, the Iowa Gambling Task (IGT). 


\section{Methods}

\subsection{Search strategy and study selection}

In March 2016, three databases (Medline/PubMed, ScienceDirect, and Web of Science) were thoroughly searched in order to identify possible papers concerning alcohol dependence and gambling disorder and the Iowa Gambling Task (IGT). We used the following search terms: ("alcohol dependence" OR "alcohol use disorder" OR "pathological gambling" OR "gambling use disorder") AND ("Iowa Gambling Task" OR "decision-making") with the filtering of "Title/Abstract", "Title, Abstract, Keywords" and "Topic" respectively for each search engine. Our literature search resulted in a total of 1198 findings relevant for inclusion in the meta-analysis. As a result of the literature search, several non peer-reviewed results were found. After examination with all authors, all grey literature (e.g.: abstracts of conference presentations or posters, unpublished dissertations) $(N=46)$ was excluded. Once these results were removed, we began screening articles for eligibility. Those papers were excluded that lacked a DSM or ICD diagnosis of either AD or GD, did not use the IGT for measuring decisionmaking $(N=846)$, used rodent or primate models $(N=50)$, or were not published in English $(N=31)$. Final papers were included if they were based on empirical data using clinically diagnosed populations (i.e.: DSM or ICD diagnosis) and measured the net score of IGT performance as an assessment of decision-making. After applying all the exclusion criteria aforementioned and removing duplicates, 17 studies met the previously set inclusion criteria for this meta-analysis (see Fig. 1).

\subsection{Meta-analysis: data extraction}

When we encountered a possibly suitable article that did not contain sufficient data concerning IGT net scores of AD or GD patients as compared to HCs to allow for inclusion in the meta-analysis, we attempted to contact the corresponding authors of the 33 studies without sufficient data up to three times over a month to ask for the missing pieces of data. As a result, Forbush et al. (2008), Zorlu et al. (2013) and Zorlu et al. (2014) sent the initial database from where the required data could be obtained; this resulted in a final study count of 17 that were included in the quantitative meta-analysis. There were 23 contrasts reported between $\mathrm{AD}$ or GD groups and HCs, which were the unit of data analysis.

\subsection{Statistical analysis}

Due to the anticipated heterogeneity, all analyses were conducted using the random-effects model, including assessment of publication bias, calculations of effect sizes, subgroup analysis, and moderator analyses. Meta-regression was conducted to investigate potential mediators such as the proportion of males, mean years of education and age. We wanted to look at other potential demographic and clinical moderator variables; however, most of the studies lacked the inclusion of data regarding potential moderators (i.e., length of abstinence). All analyses were calculated using the Comprehensive Meta Analysis (CMA) 3.0 software (Comprehensive Meta-Analysis Software (CMA), 2017).

The method of data handling was the following for each study that yielded more than one contrast: Dom et al. (2006) compared decisionmaking of HCs and alcohol dependent patients with or without personality disorders, which yielded 3 contrasts for our meta-analysis: 3 patient groups matched with HCs. Cordovil et al. (2010) measured data in 2 time points: T1 start of withdrawal, T2 end of withdrawal. We divided these two time spots and matched them with the values of the HC group. Kim et al. (2006) selected alcohol dependent patients and HCs with and without conduct disorder. In our meta-analysis, we only incorporated data from patients and HCs without conduct disorder.
Miranda et al. (2009) compared two alcohol dependent patient groups (with or without antisocial personality disorder) with a HC group, from which we matched the two patient groups with the HC group. Thus, the previously identified 17 studies yielded 23 contrast samples for our meta-analysis (Kovács et al., 2017).

The presence of publication bias was examined by conforming to the guidelines of Sterne et al. (2011). We conducted an asymmetric visual/ graphic examination of a funnel-plot, and mathematical methods for the evaluation of possible publication bias as recommended by Begg and Mazumdar (1994) and Egger et al. (1997). In Egger's test, if the $p$ value belonging to the linear regression intercept is 0.1 or smaller, there is statistically significant asymmetry. The influence and presence of outliers was assessed by the examination of standardized residual for each study. A study was considered an outlier if its standardized residual was greater than \pm 3.29 (Shiffler, 1988). The aim of calculating the effect of heterogeneity was to examine the extent the results of the studies are consistent. In our report, Q-test for heterogeneity was calculated within the two subgroups (Wiley, 2017). The Q-test for heterogeneity has an approximate $\chi 2$ distribution and it represents the degree of departure from homogeneity. A significant Q-value $(p<0.05)$ indicates statistically significant heterogeneity in the studies. In order to determine whether AD and GD group results differ, we calculated the two groups' sampling variances $\left(v_{1}\right.$, for the AD group and $v_{2}$ for the GD group) where $d$ is the observed Cohen's $d$ value, with the following formula:

$v=\frac{1}{\mathrm{n}_{1}}+\frac{1}{\mathrm{n}_{2}}+\frac{d^{2}}{2\left(n_{1}+n_{2}\right)}$

With this the two treatment groups' results could be compared with the standard normal test statistics, described by Keef and Roberts (2004) with the following formula:

$z=\frac{d_{1}-d_{2}}{\sqrt{v_{1}-v_{2}}}$

where $|z| \geq 1.96$ indicates that the group difference is statistically significant. Moderator and covariate analysis were conducted to assess the associations between the differences of patient groups and HCs regarding age, the proportion of males, and level of education, and the age of the treatment groups. Moderators were considered significant in cases of categorical variables if $Q_{\text {between }}$ was significant.

\subsection{Prisma guidelines}

This systematic review and meta-analysis is reported in accordance with the Preferred Reporting Items for Systematic Reviews and MetaAnalyses (PRISMA) statement (Moher et al., 2009) and the meta-analysis conforms to the guidelines of meta-analyses in epidemiology outlined by Stroup et al. (2000).

\section{Results}

The 17 studies and the 23 contrasts are detailed in Table 1. Overall, a total of $792 \mathrm{AD}$ or GD patients were compared to 568 HCs. The random effects estimate indicated impaired IGT performance in both AD patients $(N=500 ; d=-0.581$, CI: $-89.5<\delta<-26.6 \%)$ and GD patients $(N=292 ; d=-1.034$, CI: $-156.1<\delta<50.7 \%)$. It is also evident, that $\mathrm{AD}$ patients display less advantageous decisionmaking than controls and the same is true for GD patients (Fig. 2). In order to compare the two groups' results, sampling variances were calculated for both $\mathrm{AD}\left(v_{1}=0.0056\right)$ and GD groups $\left(v_{2}=0.0061\right)$, from which $\mathrm{z}$-score was calculated $(\mathrm{z}=-21.0785)$. This indicates a statistically significant difference between $\mathrm{AD}$ and GD groups, meaning that the overall deficit is more expressed in GD as compared to AD. 


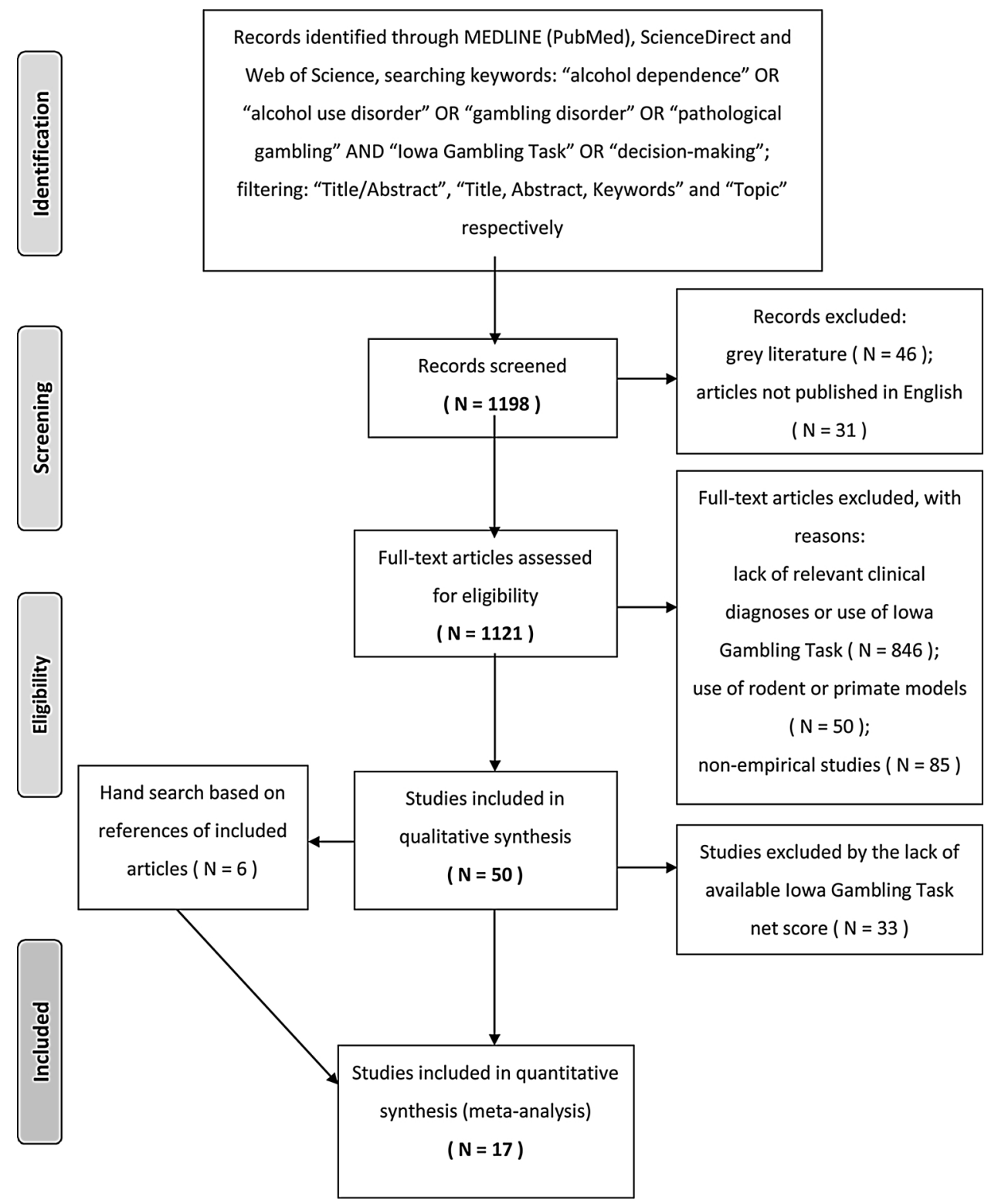

Fig. 1. PRISMA flow diagram.

\subsection{Publication bias and heterogeneity}

The funnel plot depicting standard errors appears to be symmetric for both AD (Fig. 3) and GD (Fig. 4), Egger's test for intercept indicated symmetry (intercept $=0.796, p$-value $=0.745$ ). Similarly, the Begg and Mazumdar test could not detect evidence of publication bias (Kendall's tau $=0.05929, p=0.672$ ) either.

It was estimated that there was a high likelihood of contextual and methodological heterogeneity because of the differing health service contexts regarding each study; therefore, a random effects model was utilized to calculate the summary effect estimates. There was significant heterogeneity in the sample $\left(\mathrm{Q}_{\mathrm{w}}=131.217, d f=22, p<0.001\right)$ but the two subgroups (AD: $\mathrm{Q}_{\mathrm{w}}=81.72, d f=15, p<0.001$, GD: $\left.\mathrm{Q}_{\mathrm{w}}=30.62, d f=6, p<0.001\right)$ did not differ from each other in terms of heterogeneity $\left(Q_{\mathrm{w}}=2.097, d f=1, p=0.149\right)$. Significant heterogeneity was detected, thus we conducted moderator and covariate analyses on the sample.

\subsection{Moderator and covariate analysis}

Overall 23 contrasts provided data for moderator analysis. Based on the model that incorporated the differences between patient groups and HCs regarding age (coefficient: $0.0270, p=0.48$ ) the proportion of males (coefficient: $0.0049, p=0.46$ ) and level of education in the sample (coefficient: $0.0521, p=0.50$ ) and the age of the treatment groups (coefficient: $0.0164, p=0.39$ ). None of the moderator variables had a significant effect on decision-making deficit indicated by a $p$ value less than 0.05 . We also tested each moderator separately. Since no significant difference was detected in heterogeneity between the two patient groups, the analyses were conducted on the full sample in order to increase the power of the analyses. Age difference between patient groups and HCs had no significant $p$-value (coefficient: 0.0098, $p=0.72$ ). Age of the patient groups had no significant $p$-value either (coefficient: $0.0202, p=0.24$ ). The proportion of gender in the sample was also tested and did not differ significantly (coefficient: 0.0048 , $p=0.41$ ); the level of education showed no significant $p$-value as well (coefficient: $0.0236, p=0.67$ ).

\section{Discussion}

In this study, we conducted a systematic literature search on decision-making characteristics in $\mathrm{AD}$ and GD with the use of a 


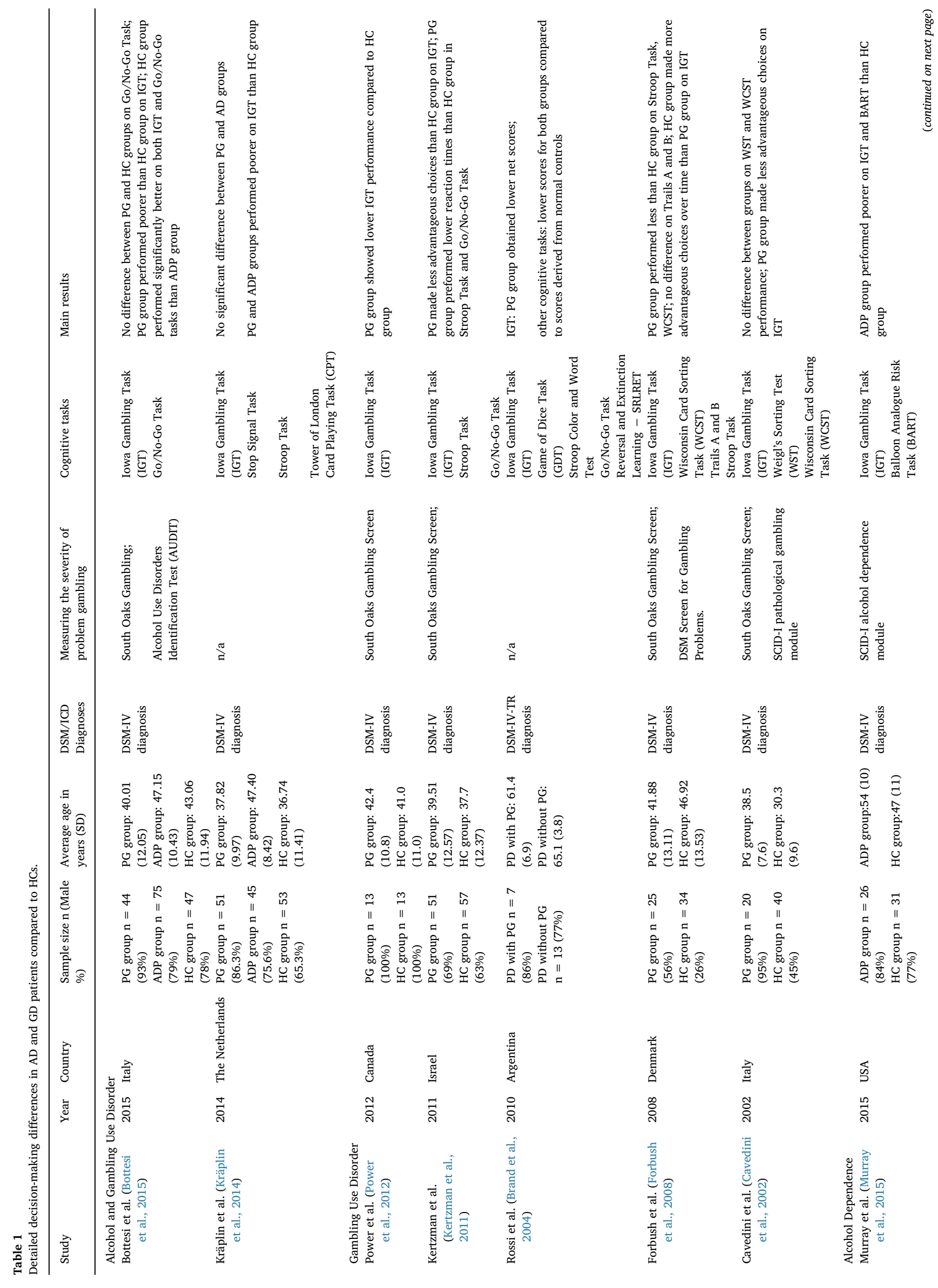




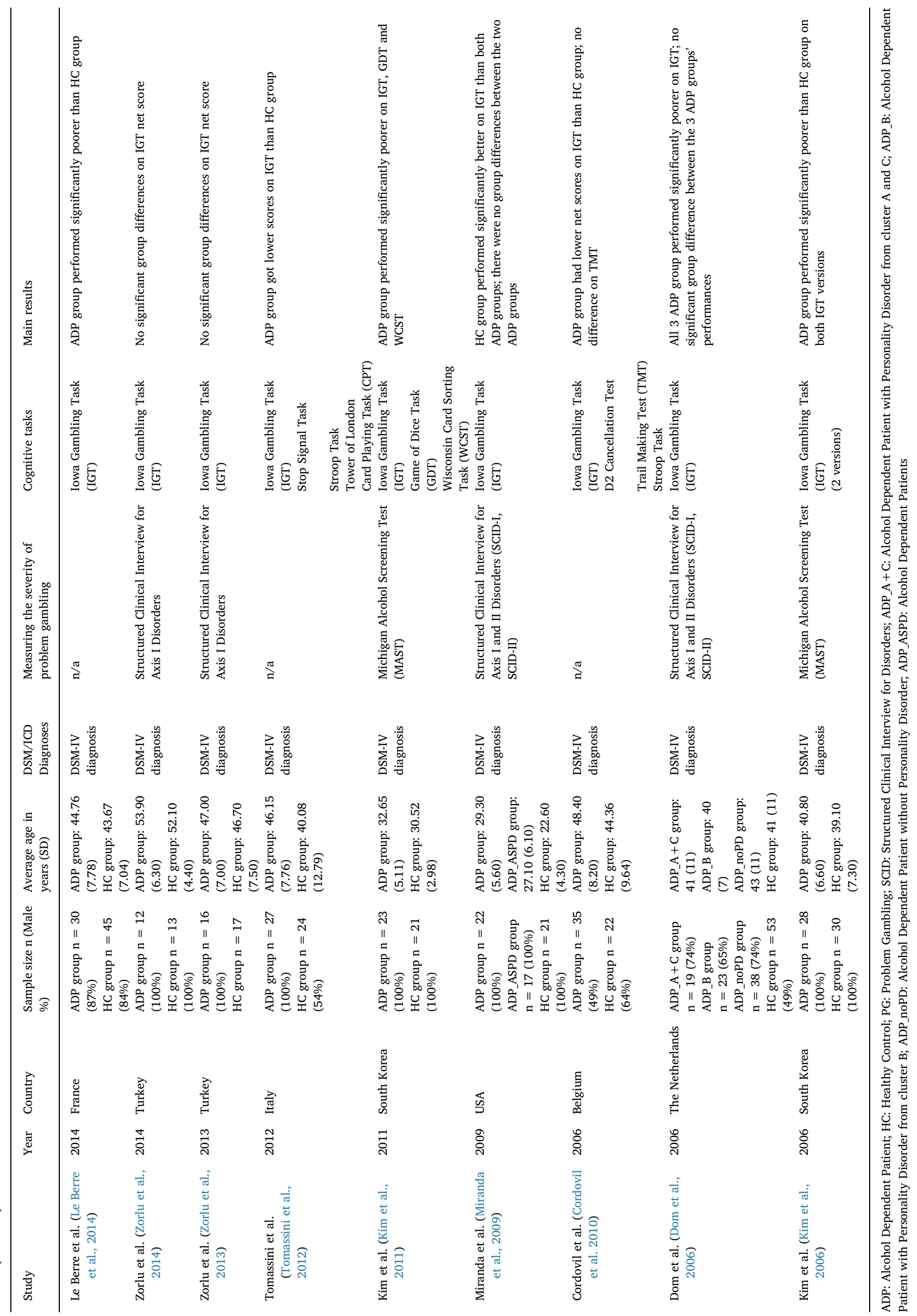




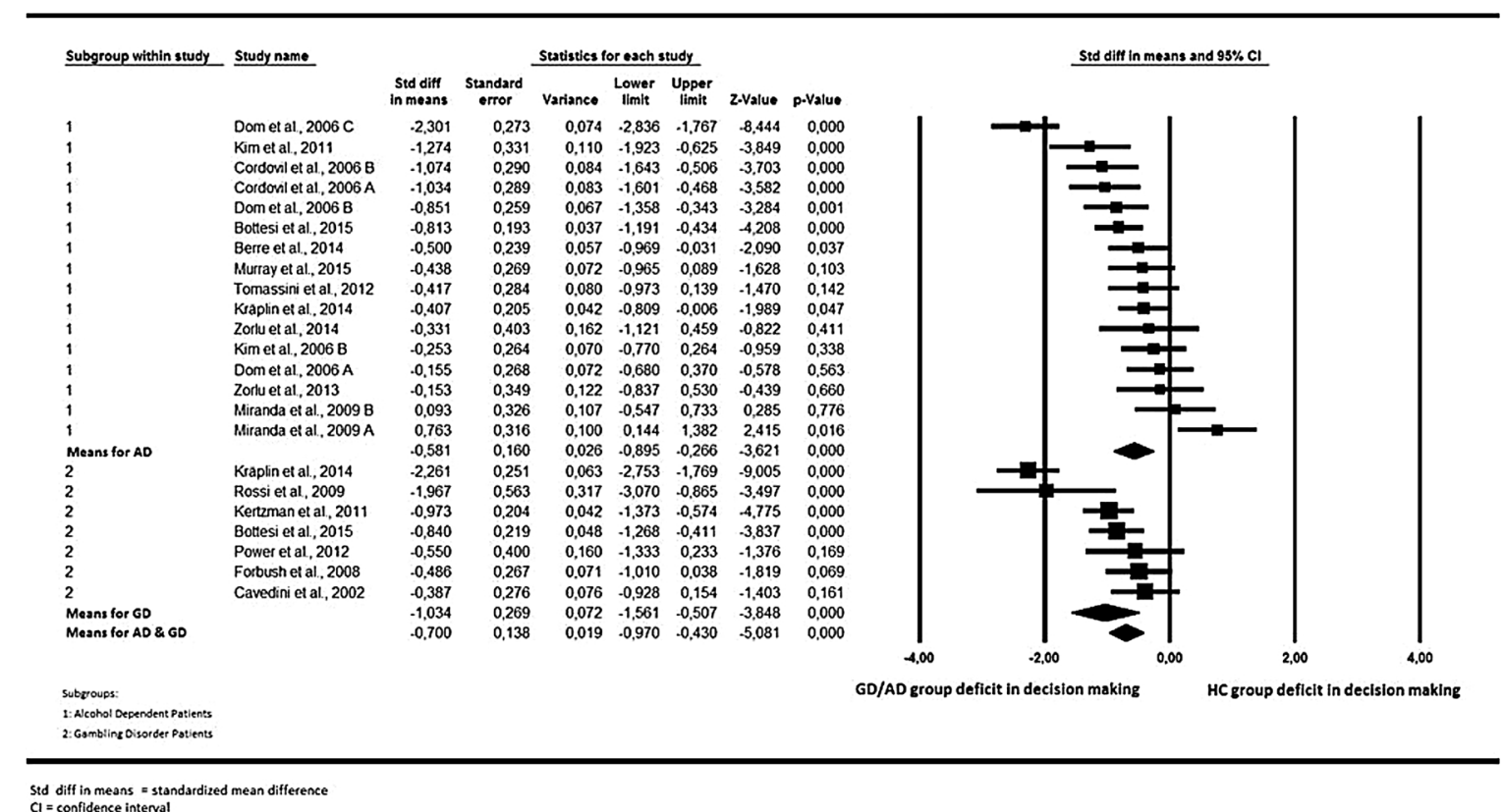

Fig. 2. Forest plot of standardized difference in means for the two subgroups.

computerized neuropsychological test: the IGT. The reason behind that is that the IGT is one of the most widely accepted and used computerized neurocognitive tasks that models real-life decision-making under laboratory circumstances (Bechara et al., 1997; Bechara, 2005). Our results focusing on the IGT are in line with other studies conducted with the use of other decision-making tasks (e.g., Delay Discounting Task or Cambridge Gambling Task) in that AD patients display significantly and substantially larger deficits in decision-making than participants of the control group (Lawrence et al., 2009b). The presence of impaired decision-making is even larger between GD patients and HC participants.

The characteristics of impulsivity and decision-making are thoroughly addressed in several mental disorders. Literature up to date is inconsistent in the existence of significant differences in IGT performance between patients with schizophrenia or schizoaffective disorder and matched healthy control groups (Alves and Rozenthal, 2006; Pedersen et al., 2017), while findings indicate that people diagnosed with bipolar disorder tend to make more risky choices than the matched control groups (though the effect is relatively small $(g=0.35)$ ) (Edge et al., 2013). However, the impairment in decision-making is also a characteristic feature of depressive disorders (Must et al., 2013), as it is in addictive disorders. Literature suggests that impaired decisionmaking represented in poor IGT performance is persistent in AD (Andó et al., 2012). This deficit might be linked to a global executive function disturbance in $\mathrm{AD}$ that is closely connected to relapse, which is considered to accompany recovery processes. Relapse prevention is highly important and a key factor of maintaining long-term abstinence and many AD patients fail to sustain prolonged abstinence, which might be owing to a decision-making deficit presented in the preference of a disadvantageous long-term strategy that is characterized by favouring an immediate reward, while disregarding future negative consequences. Since the IGT is widely accepted as a direct assessment method for measuring affective decision-making and is accepted as a clinical assessment tool in addictive disorders (Bechara, 2005), the deficit on IGT displayed by AD and GD patients compared to their matched control groups may considered to be predictive of their
Funnel Plot of Standard Error by Std diff in means

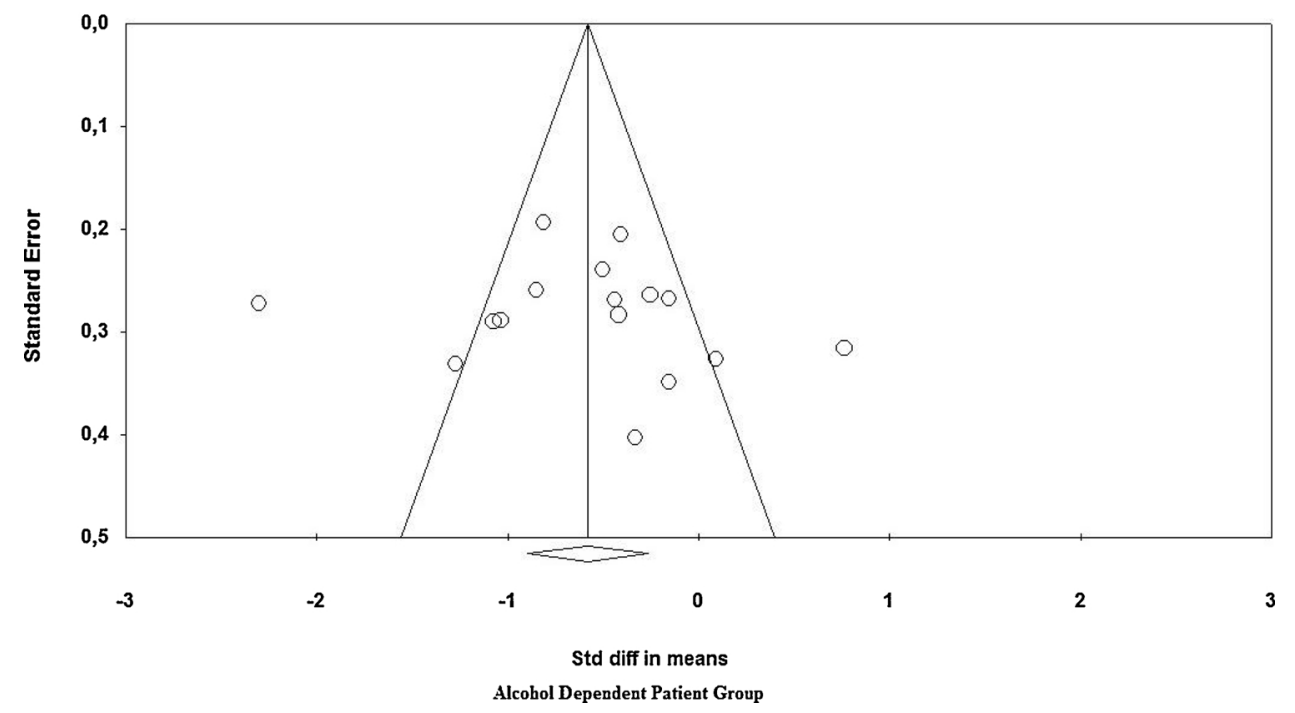

Fig. 3. Funnel Plot of Standard Error by standardized mean differences in Alcohol Dependent (AD) group. 


\section{Funnel Plot of Standard Error by Std diff in means}

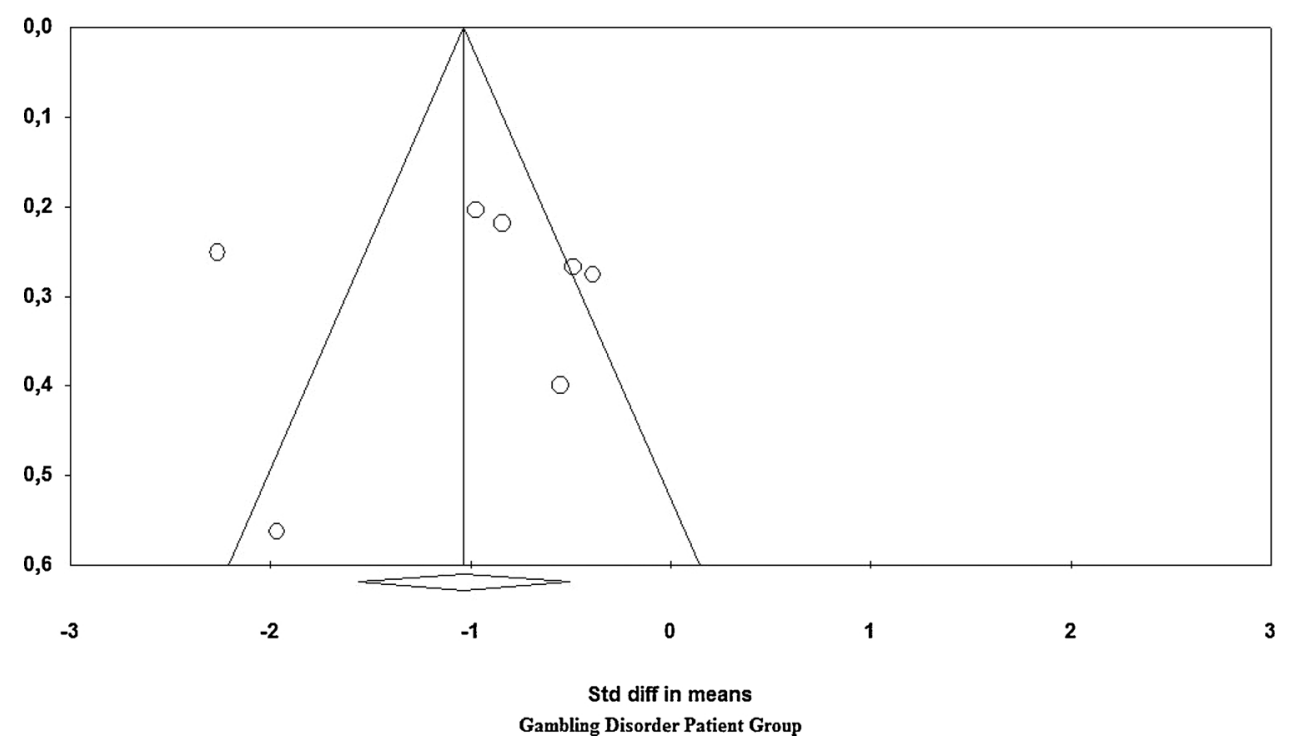

Fig. 4. Funnel Plot of Standard Error by standardized mean differences in Gambing Disorder (GD) group. lifestyle and long-term objectives. AD patients' poor performance on the IGT was also associated with premorbid personality traits as higher novelty seeking $(\mathrm{r}=-0.46, p<0.05)$ and higher reward dependence ( $\mathrm{r}=-0.50, p<0.005$ ) (Tomassini et al., 2012). Personality disorders with comorbid AD were also associated with impaired IGT performance, where cluster B personality disorders showed the highest impairment (Dom et al., 2006), while in case of GD, significantly higher sensation seeking was found compared to HC group in connection with impaired decision-making (Linnet et al., 2006). However, the effect of comorbid GD and personality disorders on decision-making is yet to be explored.

Our meta-analysis conforms to previous empirical literature that impaired decision-making may not be linked to the substance consumption itself, since it is equally and independently present in a substance-related disorder (AD), and a behaviour-related dependence (GD) as well. This also supports the recent change presented in Diagnostic and Statistical Manual of Mental Disorders (DSM-5) (American Psychiatric Association, 2013) that GD was re-categorized, and was placed among Substance-related and addictive disorders (Petry et al., 2014) as the first non-substance-related disorder in this category. GD appears to be similar to the diagnostic criteria of other substance-related dependences: addicted people continue to pursue the activity (either alcohol consumption or gambling) regardless of its long-term negative outcomes that have adverse effects on their physical, mental, and socio-economical status. A parallel can be seen between this mechanism and the measurement of long-term gain vs. short-term loss or short-term gain vs. long-term loss preference measured by the IGT.

Our results indicate that not the substance itself, but other deviations in cognitive and personality traits that accompany addictive disorders might lie in the background of this deficiency in decisionmaking. There is extensive evidence that both $\mathrm{AD}$ and GD share common underlying mechanisms, like higher impulsivity (Lawrence et al., 2009a; Verdejo-García et al., 2007), and similar deviations regarding specific personality traits as higher Neuroticism or lower Consciousness (Bagby et al., 2007; Kotov et al., 2010), and both disorders increase the likelihood for the co-occurrence of similar psychiatric disorders (e.g., mood disorders) (Lister et al., 2015). GD and AD patients also show an overlap in their neurocognitive profiles: traits like the impairment of decision-making and reflect impulsivity seem to be pre-existing vulnerability factors in the two addictions. For example, two prospective studies reported that the presence of trait impulsivity predicts later alcohol dependence (Verdejo-García et al., 2008), as well as problem gambling (Slutske et al., 2005) at a 3-year follow-up.

Although literature indicates difference in age, gender and education in the course and patterns of both AD (Crum et al., 1993; Hingson et al., 2006; Wilsnack et al., 2009) and GD (Brunborg et al., 2016; Ibáñez et al., 2001; Jiménez-Murcia et al., 2010), in our pool of data, moderator and covariate analysis of age, proportion of males and education did not provide sufficient support for the impact of these variables in the detected decision-making deficit. This may be due to the heterogeneity detected within and across the samples. Besides age, gender and education, there are several factors like intelligence, length of abstinence, and other psychopathological characteristics (e.g., levels of depression or anxiety) that may contribute to the understanding of decision-making characteristics in AD and GD. There were insufficient data available to be used in this meta-analysis, therefore future studies should account for (and report) these potential confounding effects. Thus, further empirical (and meta-analytical) research is needed to address the question whether socio-demographic and psychopathological characteristics have any effect on decision-making beyond the effect of AD and GD.

Given that reward choice deficiency is closely connected to poorer therapeutic outcomes and relapse in both AD and GD (Blum et al., 2000), our results have deep-rooted importance. Nevertheless, results should be treated with some limitations. Firstly, several from the studies identified in the systematic literature search lacked the reporting of IGT net scores and thus these studies could not be incorporated in the present meta-analysis. Moreover, to increase power of meta-analysis and effect size, more empirical studies with the report of IGT net scores should be incorporated. Due to the higher level of heterogeneity in the sample, a future meta-analysis given the availability of more incorporated studies could create subgroups within AD and GD patient groups based on the severity of their symptoms. Another factor contributing bias, which could not be completely controlled based on the articles' text is the possibility of overlap among control groups, namely that HCs matched to AD patients might contain participants affected by GD to some extent. Similarly control participants free of GD could be subjected to $\mathrm{AD}$ as well.

Decision-making is a multifaceted phenomenon which can be measured by the use of several different paradigms, from which IGT is only one of them. There are multiple reliable and valid computerized neurocognitive tasks with which decision-making deficits can be measured, but in this study, we only incorporated the IGT. Another limitation is the fact that we only incorporated articles into our systematic 
literature search and meta-analysis that were published in English. Besides omitting non-English articles, there are multiple strategies for addressing literature not written in English, but in our systematic search and meta-analysis, papers written in other languages were automatically excluded, which can implicate language bias (Grégoire et al., 1995). More detailed studies that are designed and powered to examine decision-making deficits in AD and GD are needed to clarify the relative contributions of impaired decision-making to the clinical and therapeutic outcome of these two disorders. Another important feature to note is that by our systematic literature search, we identified that the number of studies examining $\mathrm{AD}$ and GD is scarce (Bottesi et al., 2015; Kräplin et al., 2014) and despite the high comorbidity previously presented in the scientific literature (Feigelman et al., 1998; Petry et al., 2005; Stinchfield et al., 2005; Welte et al., 2001), there is no study that incorporated those patients' decision-making performance measured by the IGT who were diagnosed both with AD and GD. Conducting such an empirical study could be crucial in gaining detailed picture of the features of these two disorders, and in the examination of any possible additive effect on more characteristic decision-making deficit of simultaneous AD and GD.

\section{Role of funding source}

Nothing declared.

\section{Contributors}

All authors contributed materially to the design, running and reporting of the study. All authors have approved the final article.

\section{Declaration of interest}

All authors report no financial interests or potential conflicts of interest.

\section{Appendix A. Supplementary data}

Supplementary data associated with this article can be found, in the online version, at http://dx.doi.org/10.1016/j.drugalcdep.2017.09. 023.

\section{References}

Alves, G.S., Rozenthal, M., 2006. Neuropsychological assessment of decision-making prefrontal circuits in schizophrenia: a systematic review of the literature. Rev. Psiquiatr. Rio Gd. Sul. 28, 330-341. http://dx.doi.org/10.1590/S010181082006000300012

American Psychiatric Association, 2013. Diagnostic and Statistical Manual of Mental Disorders, fifth edition. American Psychiatric Association.

Andó, B., Must, A., Kurgyis, E., Szkaliczki, A., Drótos, G., Rózsa, S., Szikszay, P., Horváth, S., Janka, Z., Almos, P.Z., 2012. Personality traits and coping compensate for disadvantageous decision-making in long-term alcohol abstinence. Alcohol Alcohol. 47, 18-24. http://dx.doi.org/10.1093/alcalc/agr144.

Bagby, R.M., Vachon, D.D., Bulmash, E.L., Toneatto, T., Quilty, L.C., Costa, P.T., 2007. Pathological gambling and the five-factor model of personality. Personal. Individ. Differ. 43, 873-880. http://dx.doi.org/10.1016/j.paid.2007.02.011.

Bechara, A., Damasio, A.R., Damasio, H., Anderson, S.W., 1994. Insensitivity to future consequences following damage to human prefrontal cortex. Cognition 50, 7-15.

Bechara, A., Damasio, H., Tranel, D., Damasio, A.R., 1997. Deciding advantageously before knowing the advantageous strategy. Science 275, 1293-1295.

Bechara, A., 2005. Decision making, impulse control and loss of willpower to resist drugs: a neurocognitive perspective. Nat. Neurosci. 8, 1458-1463. http://dx.doi.org/10. 1038/nn1584.

Begg, C.B., Mazumdar, M., 1994. Operating characteristics of a rank correlation test for publication bias. Biometrics 50, 1088-1101. http://dx.doi.org/10.2307/2533446.

Blanco, C., Hasin, D.S., Petry, N., Stinson, F.S., Grant, B.F., 2006. Sex differences in subclinical and DSM-IV pathological gambling: results from the national epidemiologic survey on alcohol and related conditions. Psychol. Med. 36, 943-953. http://dx. doi.org/10.1017/S0033291706007410.

Blaszczynski, A., Walker, M., Sharpe, L., Nower, L., 2008. Withdrawal and tolerance phenomenon in problem gambling. Int. Gambl. Stud. 8, 179-192. http://dx.doi.org/ $10.1080 / 14459790802140007$
Blum, K., Sheridan, P.J., Wood, R.C., Braverman, E.R., Chen, T.J., Comings, D.E., 1995 Dopamine D2 receptor gene variants: association and linkage studies in impulsiveaddictive-compulsive behaviour. Pharmacogenetics 5, 121-141.

Blum, K., Braverman, E.R., Holder, J.M., Lubar, J.F., Monastra, V.J., Miller, D., Lubar, J.O., Chen, T.J., Comings, D.E., 2000. Reward deficiency syndrome: a biogenetic model for the diagnosis and treatment of impulsive addictive and compulsive behaviors. J. Psychoactive Drugs 32 (Suppl. i-iv), 1-112.

Bottesi, G., Ghisi, M., Ouimet, A.J., Tira, M.D., Sanavio, E., 2015. Compulsivity and impulsivity in pathological gambling: does a dimensional-transdiagnostic approach add clinical utility to DSM-5 classification? J. Gambl. Stud. 31, 825-847. http://dx.doi. org/10.1007/s10899-014-9470-5.

Brand, M., Labudda, K., Kalbe, E., Hilker, R., Emmans, D., Fuchs, G., Kessler, J., Markowitsch, H.J., 2004. Decision-making impairments in patients with Parkinson's disease. Behav. Neurol. 15, 77-85.

Brunborg, G.S., Hanss, D., Mentzoni, R.A., Molde, H., Pallesen, S., 2016. Problem gambling and the five-factor model of personality: a large population-based study. Addiction (Abingdon Engl.) 111, 1428-1435. http://dx.doi.org/10.1111/add.13388.

Cavedini, P., Riboldi, G., Keller, R., D’Annucci, A., Bellodi, L., 2002. Frontal lobe dysfunction in pathological gambling patients. Biol. Psychiatry 51, 334-341.

Comprehensive Meta-Analysis Software (CMA) [WWW Document], n.d. URL https:// www.meta-analysis.com/ (Accessed 13 October 2017).

Cordovil, D.S.U.M., Luminet, O., Cortesi, M., Constant, E., Derely, M., De Timary, P., 2010. Distinct effects of protracted withdrawal on affect, craving, selective attention and executive functions among alcohol-dependent patients. Alcohol Alcohol. 45, 241-246. http://dx.doi.org/10.1093/alcalc/agq012.

Crocq, M.-A., 2003. Alcohol, nicotine, caffeine, and mental disorders. Dialogues Clin. Neurosci. 5, 175-185.

Crum, R.M., Helzer, J.E., Anthony, J.C., 1993. Level of education and alcohol abuse and dependence in adulthood: a further inquiry. Am. J. Public Health 83, 830-837.

Cunningham-Williams, R.M., Cottler, L.B., Compton, W.M., Spitznagel, E.L., 1998. Taking chances: problem gamblers and mental health disorders-Results from the St. Louis Epidemiologic Catchment Area Study. Am. J. Public Health 88, 1093-1096.

Dom, G., De Wilde, B., Hulstijn, W., Van Den Brink, W., Sabbe, B., 2006. Decision-making deficits in alcohol-dependent patients with and without comorbid personality disorder. Alcohol. Clin. Exp. Res. 30, 1670-1677. http://dx.doi.org/10.1111/j.15300277.2006.00202.x.

Edge, M.D., Johnson, S.L., Ng, T., Carver, C.S., 2013. Iowa Gambling Task performance in euthymic bipolar I disorder: a meta-analysis and empirical study. J. Affect. Disord. 150, 115-122. http://dx.doi.org/10.1016/j.jad.2012.11.027.

Egger, M., Smith, G.D., Schneider, M., Minder, C., 1997. Bias in meta-analysis detected by a simple, graphical test. BMJ 315, 629-634. http://dx.doi.org/10.1136/bmj.315. 7109.629.

Feigelman, W., Wallisch, L.S., Lesieur, H.R., 1998. Problem gamblers, problem substance users, and dual-problem individuals: an epidemiological study. Am. J. Public Health $88,467-470$

Forbush, K.T., Shaw, M., Graeber, M.A., Hovick, L., Meyer, V.J., Moser, D.J., Bayless, J, Watson, D., Black, D.W., 2008. Neuropsychological characteristics and personality traits in pathological gambling. CNS Spectr. 13, 306-315.

Franken, I.H.A., van Strien, J.W., Nijs, I., Muris, P., 2008. Impulsivity is associated with behavioral decision-making deficits. Psychiatry Res. 158, 155-163. http://dx.doi. org/10.1016/j.psychres.2007.06.002.

Gilpin, N.W., Koob, G.F., 2008. Neurobiology of alcohol dependence: focus on motivational mechanisms. Alcohol Res. Health J. Natl. Inst. Alcohol Abuse Alcohol. 31, 185-195.

Goudriaan, A.E., Oosterlaan, J., de Beurs, E., van den Brink, W., 2005. Decision making in pathological gambling: a comparison between pathological gamblers, alcohol dependents, persons with Tourette syndrome, and normal controls. Brain Res. Cogn. Brain Res. 23, 137-151. http://dx.doi.org/10.1016/j.cogbrainres.2005.01.017.

Goudriaan, A.E., Oosterlaan, J., de Beurs, E., van den Brink, W., 2006. Neurocognitive functions in pathological gambling: a comparison with alcohol dependence, Tourette syndrome and normal controls. Addiction (Abingdon Engl.) 101, 534-547. http://dx. doi.org/10.1111/j.1360-0443.2006.01380.x.

Grégoire, G., Derderian, F., Le Lorier, J., 1995. Selecting the language of the publications included in a meta-analysis: is there a Tower of Babel bias? J. Clin. Epidemiol. 48, 159-163.

Hingson, R.W., Heeren, T., Winter, M.R., 2006. Age at drinking onset and alcohol dependence: age at onset, duration, and severity. Arch. Pediatr. Adolesc. Med. 160, 739-746. http://dx.doi.org/10.1001/archpedi.160.7.739.

Ibáñez, A., Blanco, C., Donahue, E., Lesieur, H.R., Pérez de Castro, I., Fernández-Piqueras, J., Sáiz-Ruiz, J., 2001. Psychiatric comorbidity in pathological gamblers seeking treatment. Am. J. Psychiatry 158, 1733-1735. http://dx.doi.org/10.1176/ajp.158. 10.1733 .

Jiménez-Murcia, S., Alvarez-Moya, E.M., Stinchfield, R., Fernández-Aranda, F., Granero, R., Aymamí, N., Gómez-Peña, M., Jaurrieta, N., Bove, F., Menchón, J.M., 2010. Age of onset in pathological gambling: clinical, therapeutic and personality correlates. J. Gambl. Stud. 26, 235-248. http://dx.doi.org/10.1007/s10899-009-9175-3.

Keef, S.P., Roberts, L.A., 2004. The meta-analysis of partial effect sizes. Br. J. Math. Stat. Psychol 57 (1), 97-129. http://dx.doi.org/10.1348/000711004849303.

Kertzman, S., Lidogoster, H., Aizer, A., Kotler, M., Dannon, P.N., 2011. Risk-taking decisions in pathological gamblers is not a result of their impaired inhibition ability. Psychiatry Res. 188, 71-77. http://dx.doi.org/10.1016/j.psychres.2011.02.021.

Kessler, R.C., Chiu, W.T., Demler, O., Walters, E.E., 2005. Prevalence, severity, and comorbidity of twelve-month DSM-IV disorders in the National Comorbidity Survey Replication (NCS-R). Arch. Gen. Psychiatry 62, 617-627. http://dx.doi.org/10.1001/ archpsyc.62.6.617.

Kim, Y.T., Lee, S.J., Kim, S.H., 2006. Effects of the history of conduct disorder on the Iowa 
Gambling Tasks. Alcohol. Clin. Exp. Res. 30, 466-472. http://dx.doi.org/10.1111/j. 1530-0277.2006.00051.x.

Kim, Y.-T., Sohn, H., Jeong, J., 2011. Delayed transition from ambiguous to risky decision making in alcohol dependence during Iowa Gambling Task. Psychiatry Res. 190, 297-303. http://dx.doi.org/10.1016/j.psychres.2011.05.003.

Kotov, R., Gamez, W., Schmidt, F., Watson, D., 2010. Linking big personality traits to anxiety, depressive, and substance use disorders: a meta-analysis. Psychol. Bull. 136, 768-821. http://dx.doi.org/10.1037/a0020327.

Kovács, I., Richman, M., Janka, Z., Maráz, A., Andó, B., 2017. Dataset for the manuscript entitled 'Decision making measured by the Iowa Gambling Task in alcohol use disorder and gambling disorder: a systematic review and meta-analysis. Figshare Data. http://dx.doi.org/10.6084/m9.figshare.5426572. https://figshare.com/s/ 29 be6b60608b325a3544.

Kräplin, A., Bühringer, G., Oosterlaan, J., van den Brink, W., Goschke, T., Goudriaan, A.E., 2014. Dimensions and disorder specificity of impulsivity in pathological gambling. Addict. Behav. 39, 1646-1651. http://dx.doi.org/10.1016/j.addbeh.2014.05. 021.

Krishnan-Sarin, S., Reynolds, B., Duhig, A.M., Smith, A., Liss, T., McFetridge, A., Cavallo, D.A., Carroll, K.M., Potenza, M.N., 2007. Behavioral impulsivity predicts treatment outcome in a smoking cessation program for adolescent smokers. Drug Alcohol Depend. 88, 79-82. http://dx.doi.org/10.1016/j.drugalcdep.2006.09.006.

Lawrence, A.J., Luty, J., Bogdan, N.A., Sahakian, B.J., Clark, L., 2009a. Impulsivity and response inhibition in alcohol dependence and problem gambling. Psychopharmacology (Berl.) 207, 163-172. http://dx.doi.org/10.1007/s00213-0091645-x.

Lawrence, A.J., Luty, J., Bogdan, N.A., Sahakian, B.J., Clark, L., 2009b. Problem gamblers share deficits in impulsive decision-making with alcohol-dependent individuals. Addiction (Abingdon Engl.) 104, 1006-1015. http://dx.doi.org/10.1111/j.13600443.2009.02533.x.

Le Berre, A.-P., Rauchs, G., La Joie, R., Mézenge, F., Boudehent, C., Vabret, F., Segobin, S., Viader, F., Allain, P., Eustache, F., Pitel, A.-L., Beaunieux, H., 2014. Impaired decision-making and brain shrinkage in alcoholism. Eur. Psychiatry 29, 125-133. http:// dx.doi.org/10.1016/j.eurpsy.2012.10.002.

Ledgerwood, D.M., Petry, N.M., 2006. What do we know about relapse in pathological gambling? Clin. Psychol. Rev. 26, 216-228. http://dx.doi.org/10.1016/j.cpr.2005. 11.008.

Linnet, J., Røjskjaer, S., Nygaard, J., Maher, B.A., 2006. Episodic chasing in pathological gamblers using the Iowa gambling task. Scand. J. Psychol. 47, 43-49. http://dx.doi. $\operatorname{org} / 10.1111 / j .1467-9450.2006 .00491 . x$.

Lister, J.J., Milosevic, A., Ledgerwood, D.M., 2015. Psychological characteristics of problem gamblers with and without mood disorder. Can. J. Psychiatry Rev. Can. Psychiatr. 60, 369-376.

Markham, F., Young, M., Doran, B., 2012. The relationship between alcohol consumption, gambling behaviour and problem gambling during a single visit to a gambling venue. Drug Alcohol Rev. 31, 770-777. http://dx.doi.org/10.1111/j.1465-3362.2012. 00430.x.

Miranda, R., MacKillop, J., Meyerson, L.A., Justus, A., Lovallo, W.R., 2009. Influence of antisocial and psychopathic traits on decision-making biases in alcoholics. Alcohol. Clin. Exp. Res. 33, 817-825. http://dx.doi.org/10.1111/j.1530-0277.2009.00901.x.

Moeller, F.G., Dougherty, D.M., Barratt, E.S., Schmitz, J.M., Swann, A.C., Grabowski, J., 2001. The impact of impulsivity on cocaine use and retention in treatment. J. Subst. Abuse Treat. 21, 193-198.

Moher, D., Liberati, A., Tetzlaff, J., Altman, D.G., PRISMA Group, 2009. Preferred reporting items for systematic reviews and meta-analyses: the PRISMA statement. Ann. Intern. Med. 151, 264-269 (W64).

Morgan, M.J., Impallomeni, L.C., Pirona, A., Rogers, R.D., 2006. Elevated impulsivity and impaired decision-making in abstinent Ecstasy (MDMA) users compared to polydrug and drug-naïve controls. Neuropsychopharmacol 31, 1562-1573. http://dx.doi.org/ 10.1038/sj.npp.1300953.

Murray, D.E., Durazzo, T.C., Mon, A., Schmidt, T.P., Meyerhoff, D.J., 2015. Brain perfusion in polysubstance users: relationship to substance and tobacco use, cognition, and self-regulation. Drug Alcohol Depend. 150, 120-128. http://dx.doi.org/10.1016/ j.drugalcdep.2015.02.022.

Must, A., Horvath, S., Nemeth, V.L., Janka, Z., 2013. The Iowa Gambling Task in depression - What have we learned about sub-optimal decision-making strategies? Front. Psychol. 4, 732. http://dx.doi.org/10.3389/fpsyg.2013.00732.

Pedersen, A., Göder, R., Tomczyk, S., Ohrmann, P., 2017. Risky decision-making under risk in schizophrenia: a deliberate choice? J. Behav. Ther. Exp. Psychiatry 56, 57-64. http://dx.doi.org/10.1016/j.jbtep.2016.08.004.

Petry, N.M., Stinson, F.S., Grant, B.F., 2005. Comorbidity of DSM-IV pathological gambling and other psychiatric disorders: results from the national epidemiologic survey on alcohol and related conditions. J. Clin. Psychiatry 66, 564-574.

Petry, N.M., Blanco, C., Auriacombe, M., Borges, G., Bucholz, K., Crowley, T.J., Grant, B.F., Hasin, D.S., O'Brien, C., 2014. An overview of and rationale for changes proposed for pathological gambling in DSM-5. J. Gambl. Stud. 30, 493-502. http://dx. doi.org/10.1007/s10899-013-9370-0.

Potenza, M.N., 2001. The neurobiology of pathological gambling. Semin. Clin. Neuropsychiatry 6, 217-226.

Potenza, M.N., 2013. Neurobiology of gambling behaviors. Curr. Opin. Neurobiol. 23, 660-667. http://dx.doi.org/10.1016/j.conb.2013.03.004.

Power, Y., Goodyear, B., Crockford, D., 2012. Neural correlates of pathological gamblers preference for immediate rewards during the iowa gambling task: an fMRI study. J. Gambl. Stud. 28, 623-636. http://dx.doi.org/10.1007/s10899-011-9278-5.

Shiffler, R.E., 1988. Maximum z scores and outliers. Am. Stat. 42, 79-80. http://dx.doi. org/10.1080/00031305.1988.10475530.

Slutske, W.S., Caspi, A., Moffitt, T.E., Poulton, R., 2005. Personality and problem gambling: a prospective study of a birth cohort of young adults. Arch. Gen. Psychiatry 62, 769-775. http://dx.doi.org/10.1001/archpsyc.62.7.769.

Slutske, W.S., Zhu, G., Meier, M.H., Martin, N.G., 2010. Genetic and environmental influences on disordered gambling in men and women. Arch. Gen. Psychiatry 67, 624-630. http://dx.doi.org/10.1001/archgenpsychiatry.2010.51.

Sproston, K., Hing, N., Palankay, C., 2012. Prevalence of Gambling and Problem Gambling in New South Wale. Ogilvy Illumination, Sydney, Australia.

Sterne, J.A.C., Sutton, A.J., Ioannidis, J.P.A., Terrin, N., Jones, D.R., Lau, J., Carpenter, J., Rücker, G., Harbord, R.M., Schmid, C.H., Tetzlaff, J., Deeks, J.J., Peters, J., Macaskill, P., Schwarzer, G., Duval, S., Altman, D.G., Moher, D., Higgins, J.P.T., 2011. Recommendations for examining and interpreting funnel plot asymmetry in metaanalyses of randomised controlled trials. BMJ 343, d4002.

Stinchfield, R., Kushner, M.G., Winters, K.C., 2005. Alcohol use and prior substance abuse treatment in relation to gambling problem severity and gambling treatment outcome. J. Gambl. Stud. 21, 273-297. http://dx.doi.org/10.1007/s10899-005-3100-1.

Stoltenberg, S.F., Batien, B.D., Birgenheir, D.G., 2008. Does gender moderate associations among impulsivity and health-risk behaviors? Addict. Behav. 33, 252-265. http://dx. doi.org/10.1016/j.addbeh.2007.09.004.

Stroup, D.F., Berlin, J.A., Morton, S.C., Olkin, I., Williamson, G.D., Rennie, D., Moher, D., Becker, B.J., Sipe, T.A., Thacker, S.B., 2000. Meta-analysis of observational studies in epidemiology: a proposal for reporting: meta-analysis Of Observational Studies in Epidemiology (MOOSE) group. JAMA 283, 2008-2012.

Tomassini, A., Struglia, F., Spaziani, D., Pacifico, R., Stratta, P., Rossi, A., 2012. Decision making, impulsivity, and personality traits in alcohol-dependent subjects. Am. J. Addict. 21, 263-267. http://dx.doi.org/10.1111/j.1521-0391.2012.00225.x.

Verdejo-García, A., Bechara, A., Recknor, E.C., Pérez-García, M., 2007. Negative emotiondriven impulsivity predicts substance dependence problems. Drug Alcohol Depend. 91, 213-219. http://dx.doi.org/10.1016/j.drugalcdep.2007.05.025.

Verdejo-García, A., Lawrence, A.J., Clark, L., 2008. Impulsivity as a vulnerability marker for substance-use disorders: review of findings from high-risk research, problem gamblers and genetic association studies. Neurosci. Biobehav. Rev. 32, 777-810. http://dx.doi.org/10.1016/j.neubiorev.2007.11.003.

Welte, J., Barnes, G., Wieczorek, W., Tidwell, M.C., Parker, J., 2001. Alcohol and gambling pathology among U.S. adults: prevalence: demographic patterns and comorbidity. J. Stud. Alcohol 62, 706-712.

Wiley, 2017. Introduction to Meta-Analysis - Michael Borenstein. Larry V. Hedges, Julian P. T. Higgins [WWW Document], n.d. URL http://eu.wiley.com/WileyCDA/ WileyTitle/productCd-EHEP002313.html (Accessed 3 October 2016).

Wilsnack, R.W., Wilsnack, S.C., Kristjanson, A.F., Vogeltanz-Holm, N.D., Gmel, G., 2009. Gender and alcohol consumption: patterns from the multinational GENACIS project. Addiction (Abingdon Engl.) 104, 1487-1500. http://dx.doi.org/10.1111/j.1360 0443.2009.02696.x.

Zorlu, N., Gelal, F., Kuserli, A., Cenik, E., Durmaz, E., Saricicek, A., Gulseren, S., 2013. Abnormal white matter integrity and decision-making deficits in alcohol dependence. Psychiatry Res. 214, 382-388. http://dx.doi.org/10.1016/j.pscychresns.2013.06. 014.

Zorlu, N., Karavul Ucman, T., Gelal, F., Colak Kalayci, C., Polat, S., Saricicek, A., Kurtgöz Zorlu, P., Gulseren, S., 2014. Abnormal white matter integrity in long-term abstinent alcohol dependent patients. Psychiatry Res. 224, 42-48. http://dx.doi.org/10.1016/ j.pscychresns.2014.07.006.

de Castro, V., Fong, T., Rosenthal, R.J., Tavares, H., 2007. A comparison of craving and emotional states between pathological gamblers and alcoholics. Addict. Behav. 32, 1555-1564. http://dx.doi.org/10.1016/j.addbeh.2006.11.014. 
III. 


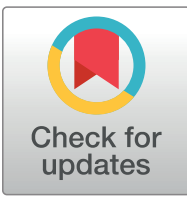

\section{G OPENACCESS}

Citation: Kovács I, Demeter I, Janka Z, Demetrovics Z, Maraz A, Andó B (2020) Different aspects of impulsivity in chronic alcohol use disorder with and without comorbid problem gambling. PLOS ONE 15(1): e0227645. https://doi. org/10.1371/journal.pone.0227645

Editor: Simone Rodda, University of Auckland, NEW ZEALAND

Received: August 24, 2019

Accepted: December 23, 2019

Published: January 30, 2020

Copyright: @ 2020 Kovács et al. This is an open access article distributed under the terms of the Creative Commons Attribution License, which permits unrestricted use, distribution, and reproduction in any medium, provided the original author and source are credited.

Data Availability Statement: The data underlying the results presented in the study are available from https://dx.doi.org/10.6084/m9.figshare. 11473296

Funding: The authors received no specific funding for this work.

Competing interests: NO authors have competing interests.
RESEARCH ARTICLE

\section{Different aspects of impulsivity in chronic alcohol use disorder with and without comorbid problem gambling}

\author{
Ildikó Kovács ${ }^{1}{ }^{*}$, Ildikó Demeter ${ }^{1}$, Zoltán Janka' ${ }^{1}$, Zsolt Demetrovics ${ }^{2}$, Aniko Maraz ${ }^{3 \odot}$, \\ Bálint Andó ${ }^{10}$
}

1 Department of Psychiatry, Faculty of Medicine, University of Szeged, Szeged, Hungary, 2 Institute of Psychology, Eötvös Loránd University, Budapest, Hungary, 3 Institute für Psychologie, Humboldt-Universität zu Berlin, Berlin, Germany

๑ These authors contributed equally to this work.

* kovacs.ildiko.1@med.u-szeged.hu

\section{Abstract}

\section{Background and aims}

Alcohol use disorder (AUD) and problem gambling are highly comorbid disorders. This study aims to explore the role of four aspects of impulsivity (trait concept of impulsivity, choice impulsivity, impulsive aggression and response inhibition/decision-making) in longterm chronic AUD patients with and without problem or pathological gambling symptoms.

\section{Methods}

Cognitively intact chronic AUD patients were enrolled with $(n=32)$ and without $(n=71)$ problem gambling symptoms in an inpatient clinic for chronic alcohol users. Multiple facets of impulsivity, cognitive ability, psychopathological symptoms, alcohol and gambling severity were measured.

\section{Results}

Chronic AUD patients with gambling disorder symptoms showed longer lifetime alcohol consumption, more severe alcohol use and higher psychopathological symptom severity than AUD patients without gambling symptoms. Gambling severity correlated with overall trait impulsivity, but not with choice impulsivity, impulsive aggression or cognitive impulsivity with controlling for lifetime alcohol consumption, lifetime alcohol use and psychopathological symptom severity. High trait impulsivity and non-planning was associated with comorbid gambling symptoms in AUD patients, which was independent of the level of intelligence, age and psychopathological symptoms.

\section{Conclusion}

Comorbid gambling disorder symptoms in chronic AUD was connected to more severe alcohol-related variables. Higher trait impulsivity was also linked with gambling disorder 
symptoms in patients with chronic AUD. This accents the need of special focus on comorbid GD symptoms in AUD, since prognosis and treatment for them may vary.

\section{Introduction}

Alcohol use disorder (AUD) is one of the most frequently occurring substance use disorder, and it exhibits exceptionally high lifetime prevalence rate (30.3\%) [1]. Chronic AUD is highly comorbid with many systemic diseases and is often present simultaneously with other mental disorders [2], from which the high co-occurrence of gambling disorder (GD) and AUD is well established. Studies have shown that AUD and GD are highly comorbid both in community $[3,4]$ and in treatment seeking samples [5,6]. In a nationally representative US study, almost three-quarters (73.2\%) of lifetime GD patients had AUD [7], while a population-based metaanalysis reported that $28 \%$ of lifetime GD patients report AUD as well [8], and other studies reported a $17-33 \%$ comorbidity of current GD in AUD patients [9,10]. AUD and GD share common symptomatology and demonstrate common underlying genetic vulnerabilities [11], from which impulsivity is considered to be an endophenotypic indicator in both disorders $[12,13]$. Moreover, there is evidence that higher impulsivity may not only be present for the clinical presentation of GD, but may also be present in case of milder, subclinical problem gambling $[3,14,15]$.

Impulsivity can be defined as a complex, multidimensional construct that is frequently described as the repetitive execution of maladaptive behaviours resulting in potential negative consequences. Hence, impulsive actions can be regarded as unplanned and rapid reactions to external or internal stimuli with the aim of obtaining immediate gratification and/or pleasure $[12,16]$. Contemporary models of impulsivity highlight the importance of not only behavioural aspects of impulsiveness, but also underlying neuropsychological components [17-19].

Impulsivity show complex neurobiological underpinnings, where the neurobiological and behavioural relationships between AUD, GD and impulsivity have been well documented $[20,21]$. The neurotoxic effects of chronic administration of alcohol and prolonged gambling behaviour are known to cause neural loss in "top-down" control regions of the brain, in the prefrontal cortex, the orbitofrontal cortex, the superior frontal association cortex, the supraoptic and paraventricular nuclei of the hypothalamus and the cerebellum, which have critical role in response inhibition, affective processing and decision-making, thus in impulsivity [22-24]. A diagnostic feature of both AUD and GD is the inability to abstain from the addictive behaviour even when facing severe negative consequences [25-27]. Such a failure in controlling one's actions indicates inadequate inhibitory control, in which patients are unable to suppress the undesired, maladaptive act of gambling or drinking behaviour. This impairment reflects on deteriorated inhibitory control and decision-making, which represent a form of impulsivity $[27,28]$.

Early impulsivity is proven to be a predictor of heavy drinking and also gambling behaviour in later life [29-31]. Moreover, there is evidence that the acute administration of alcohol and gambling activity induce impulsivity in humans $[27,32]$. This directly leads to impulsive behaviour evolving into compulsion that is linked to the development of the chronic forms of AUD and GD [33], where impulsivity has been frequently connected to poor clinical outcomes $[34,35]$ and is associated with negative concomitant features like increased relapse risk [36] or increased alcohol consumption and more severe gambling behaviour [37-39]. 
Extensive literature exists on either diagnosed AUD or GD and their relations to impulsivity compared with healthy control groups, but up to now, only few studies have examined and compared AUD and GD patients in the same study in terms of any facet of impulsivity. [40] compared the differences of cognitive impulsivity measured by 2 neuropsychological tasks of 21 non-treatment-seeking problem or pathological gamblers and 21 AUD outpatients with healthy controls. They found shared deficits in ventral prefrontal cortical functions, while in tasks loading on dorsolateral prefrontal cortical functions were only impaired in AUD patients, presumably as a consequence of long-term alcohol consumption. [41] examined the differences of 3 decision-making tasks in 48 GD and 46 AUD outpatients and found that AUD patients performed marginally worse than the GD group. [42] studied the differences of a selfreported and a cognitive impulsivity task of 75 AUD and 44 GD patients recruited from mixed inpatient and outpatient settings. They revealed similar patterns of impulsivity in AUD and GD patients. These studies examined single diagnosis of AUD or GD; however, we could not identify studies that examined the subclinical emergence of problem gambling in hospitalised chronic AUD patients and its relations to impulsivity utilizing a comprehensive assessment battery.

Since impulsivity is not only proven to be a diagnostic criterion and a risk factor for AUD and GD, but the long-term alcohol exposure and gambling behaviour might further result in the impairment of impulse control, which prompts the emergence of AUD and GD. Moreover, a recently published meta-analysis indicated that the impairment of some executive functions, particularly impulsive decision-making were even higher in patients with a non-substancerelated addictive disorder (GD) than in patients with the substance-related condition of AUD [43]. Based on these, it is paramount to explore the different aspects of impulsivity and their presentation in long-term AUD patients, and whether the existence of comorbid GD symptoms differentiate them in terms of impulsivity.

Due to the multidimensional nature of impulsivity, we aimed to explore it from a complex point of view, incorporating both objective and subjective measures of impulsiveness: i) traditional trait concept of impulsivity, which represents the execution of nonplanned actions and the engagement in maladaptive behaviours with disregarding potential future consequences $[44,45]$; ii) the inability of delaying gratifications or discarding rewards as a measure of choice impulsivity [46]; iii) impulsive aggression [47]; iv) deficits in response inhibition and decisionmaking $[48,49]$.

To our knowledge, this is the first study that explores the associations of different aspects of impulsivity in chronic AUD patients compared to chronic AUD patients with comorbid GD symptoms. We hypothesised that those AUD patients who exhibit comorbid GD symptoms are distinct from AUD patients without GD symptoms by expressing higher symptom severity of substance use and demonstrating higher levels of trait impulsivity, choice impulsivity, impulsive aggression and impulsive decision-making.

\section{Methods}

\section{Procedure}

A comprehensive research project was conducted at the Department of Psychiatry, Faculty of Medicine, University of Szeged, Hungary. Patients receiving inpatient treatment for chronic alcohol use disorder (AUD) were assessed for executive functions, personality traits, addiction characteristics, comorbid psychiatric conditions, addictive disorders and psychopathological symptom severity. In this part of the study, which focuses on the evaluation of objective and subjective measures of impulsivity, a total of 104 patients were enrolled. Patients who met the inclusion criteria of having an established DSM-5 diagnosis of AUD, who finished at least 
primary education and whose level of intelligence surpassed the level of intellectual disability (Fourth Edition of the Weschler Adult Intelligence Scale above 70) were included. Patients who had a history of any psychosis spectrum disorder, progressive neurodegenerative disorders, neurological diseases, diseases affecting their sight or reported acute alcohol abuse were excluded from this study. One recruited patient was excluded due to voluntary termination of inpatient treatment; thus, the final sample size was 103. Patients were classified into two groups based on the presence of comorbid GD symptoms (see Fig 1).

The study was conducted in accordance with the Declaration of Helsinki and was approved by the Human Investigation Review Board, University of Szeged (ethical approval number: 49/ B-53/2016KK). Written informed consent was obtained from each participant.

\section{Measures}

Barratt Impulsivity Scale (BIS). The Hungarian version of the BIS-11 is based on the original English version [45], which contains 30 items measuring three dimensions of impulsivity: motor impulsivity, attentional impulsivity and nonplanning. Items are measured on a scale ranging from 0 to 3; higher scores indicate higher impulsivity. The Hungarian version adapted by [50] showed good reliability in our sample: Cronbach's $\alpha=0.805$.

Buss-Perry Aggression Questionnaire (BPAQ). The Buss-Perry Aggression Questionnaire is a widely-used self-evaluation test for measuring aggressive impulses in 4 facets: physical and verbal aggression, hostility and anger [51]. The Hungarian version was adapted by [52], and showed good internal consistency and reliability (in our sample: Cronbach's $\alpha=0.879$ ).

Delay Discounting Task (DDT). In the Delay Discounting Task participants are presented with a series of monetary choices in which they have to decide between two different amounts of money, which they hypothetically receive in different time intervals. Once displayed, the rewards vary between 0HUF and 55,000HUF in 2,500HUF increments ( 1 EUR is about 320 HUF). The two choices differ in receival times, which vary in $0,1,14,60,180$ or 365 days; the receival of one amount being closer in time (e.g. "now") and the other being later ("in 2 weeks"). The task consists of 138 hypothetical questions that are presented in random order (i.e., Which of the two choices would you select? 10,000HUF now or 55,000HUF two weeks later?). Patients indicate their choices by a single click on their preferred selection, then they could continue the test by clicking on the 'Next question' button. The aim of the DDT is to determine the point at which the selection of the immediate reward was preferred over the delayed reward, which is known as the 'indifference point', and it can be computed for each period of delay. The participant selects the immediate available selection above this indifference point (which is given in HUF), while below the indifference point the participant chooses the option with delay.

Iowa Gambling Task (IGT). The Iowa Gambling Task is one of the most frequently used and ecologically valid assessment tools for measuring decision-making, in which participants are asked to choose 100 times from four decks of cards with different win/loss ratio to win as much money as they can. For this, participants have to abandon short-term advantageous choices that would result in immediate high rewards accompanied with more/higher losses and instead, they need to select from decks, which result in lower immediate rewards, but lower long-term losses as well, turning out to be long-term advantageous choices [26,53]. For data analysis, choices were divided into five blocks ( 20 selections in each block). The amount of money won, and the total net score calculated by subtracting the number of advantageous selections from disadvantageous choices were also compared.

Wisconsin Card Sorting Task (WCST). The WCST measures cognitive flexibility, executive functions and decision-making [54]. In this neuropsychological task, participants need to 


\section{PRISMA 2009 Flow Diagram}

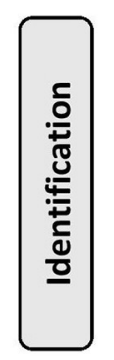

Patients receiving treatment for addictive disorders reviewed at the

Department of Psychiatry,

University of Szeged, Hungary

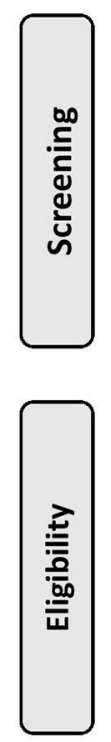

Inclusion criteria:

-DSM-5 diagnosis of AUD

-Finished primary education

-Level of intelligence above intellectual disability (WASI-IV $\mathrm{IQ}>70)$
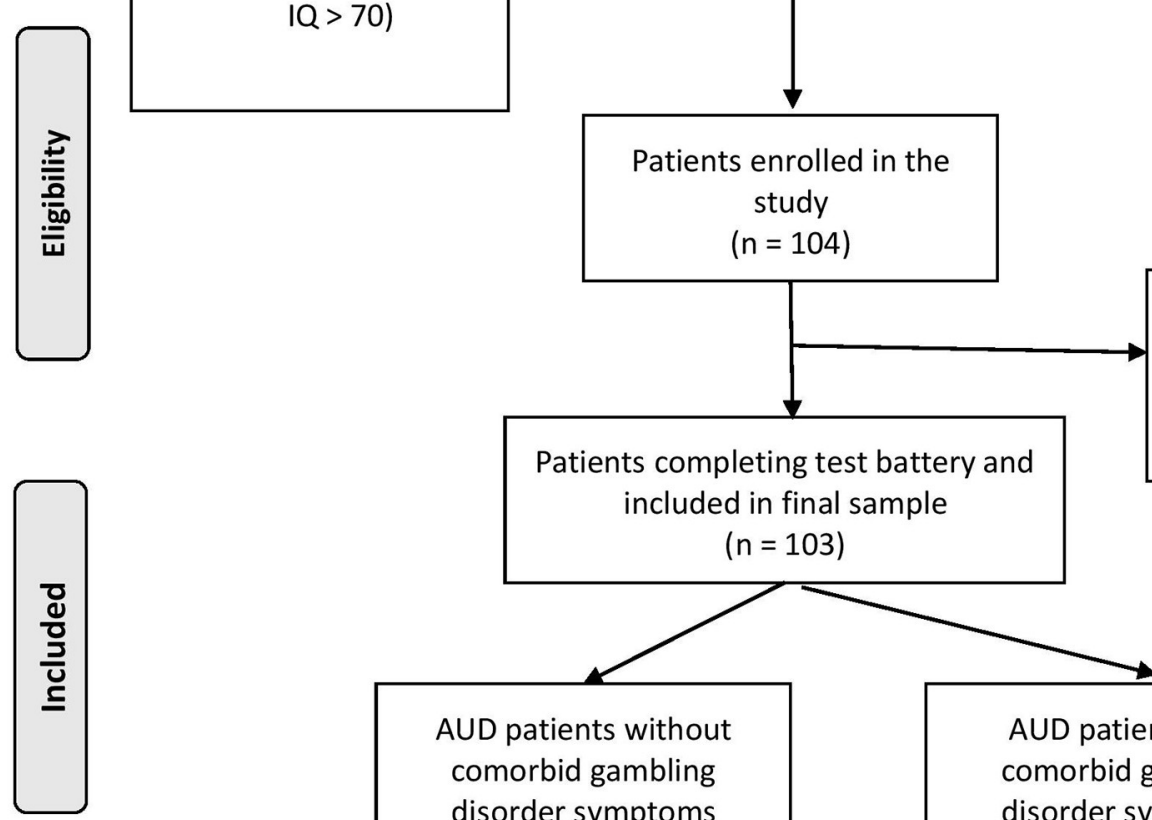

Patient excluded due to early termination of treatment $(n=1)$

Patients completing test battery and included in final sample

Exclusion criteria: -comorbid progressive neurodegenerative diseases, -comorbid neurological disorders -comorbid psychosis spectrum disorders -diseases affecting sight (e.g. dyschromatopsia)

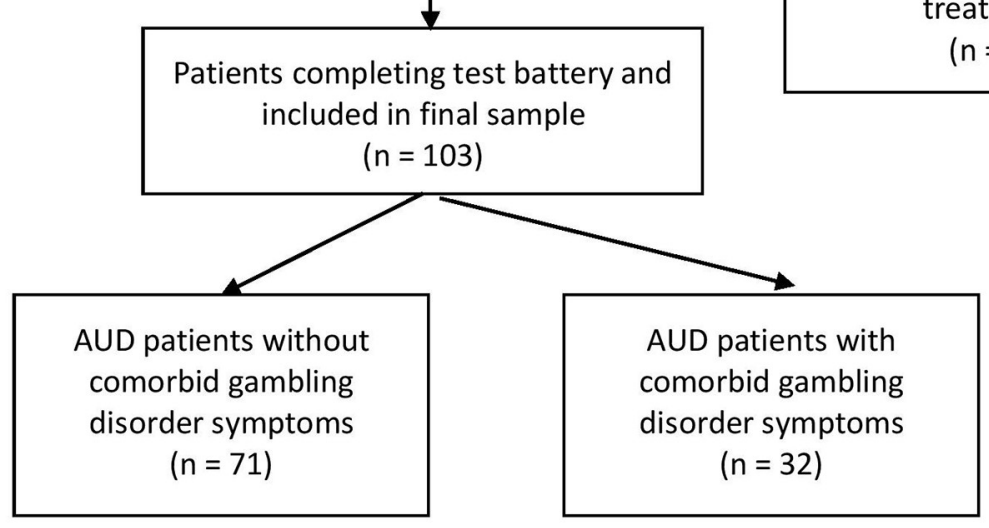

From: Moher D, Liberati A, Tetzlaff J, Altman DG, The PRISMA Group (2009). Preferred Reporting Items for Systematic Reviews and MetaAnalyses: The PRISMA Statement. PLoS Med 6(7): e1000097. doi:10.1371/journal.pmed1000097

For more information, visit www.prisma-statement.org.

Fig 1. PRISMA flowchart of selection procedure. DSM: The Diagnostic and Statistical Manual of Mental Disorders, Fifth Edition; AUD: alcohol use disorder; WAIS-IV: The Wechsler Adult Intelligence Scale, Fourth Edition.

https://doi.org/10.1371/journal.pone.0227645.g001 
sort cards according to various criteria with the only feedback of the classification being correct or incorrect. Four sample cards are presented differing in pattern, colour and number of patterns to which participants need to match newly appearing cards. Cards can be classified according to their colour, their patterns or the number of patterns on each card. The classification rule changes every ten cards, which implies that when the participant has figured out the classification rule, they would eventually start making mistakes when the rule changes, and consequently they need to adapt to the changing rules. In our study we used the PEBL's computerised version of card sorting task $[55,56]$. For data analysis, the number of correct responses, the number of incorrect responses and the number of perseverative errors were calculated.

Wechsler Adult Intelligence Scale (WAIS-IV). The WAIS-IV is the most widely used intelligence scale to measure cognitive ability. The test consists of 10 subtests and 5 supplementary tests, which measure 4 major components of intelligence: Verbal Comprehension Index (VCI), Perceptual Reasoning Index (PRI), Working Memory Index (WMI) and Processing Speed Index (PSI) [57]. The Hungarian standardization was made by [58]. In this study, we calculated the WAIS-IV total score, which is the combined performance of the VCI, PRI, WMI and PSI.

Addiction Severity Index (ASI). The ASI is a semi-structured interview, which covers 7 potential problematic areas (Medical, Employment/Support Status, Alcohol, Drug, Legal, Family/Social and Psychiatric) covering recent and lifetime substance-related problems [59]. The Hungarian adaptation was made by Rácz, Pogány \& Máthé-Árvay (2002) [60]. From the interview, the following variables were selected: start of alcohol misuse in years, lifetime alcohol consumption in years, and abstinence during last 30 days.

South Oaks Gambling Screen (SOGS). The South Oaks Gambling Screen is a 20-item questionnaire based on the DSM-III criteria of pathological gambling [61]. The Hungarian version was adapted by [62] and demonstrated good internal consistency. Scores between 1 and 4 show problematic gambling, while 5 or more points indicate probable pathological gambling.

Alcohol Use Disorders Identification Test (AUDIT). The AUDIT is a 10-item self-evaluation screening test for assessing the severity of alcohol use and its adverse consequences developed by the World Health Organization [63]. The Hungarian adaptation by Gerevich, Bácskai \& Rózsa (2006) [64] exhibited good validity and reliability (in our sample: Cronbach’s $\alpha=0.763)$.

Symptom Checklist-90-R. The Symptom Checklist-90-R is a 90-item self-report questionnaire for assessing a broad range of currently existing psychopathological symptoms [65]. Items are rated on a $0-4$ scale where more points indicate the presence of more severe symptoms during the past week. The test measures nine symptom dimensions, and one of its three global indices, the Global Severity Index (GSI) can be used as an indicator of the severity of psychopathological symptoms. The Hungarian version showed excellent internal consistency and reliability in our sample: Cronbach's $\alpha=0.953$ [66,67].

Data analysis. Data analysis was conducted with IBM SPSS Statistics 24.0 software [68]. Based on the results of the SOGS, we divided our sample into two groups: 1) AUD who scored 0 on the SOGS were categorised as AUD patients without gambling symptoms (AUD group) and 2) those patients who scored 1 or above were labelled as AUD patients with probable or problem gambling symptoms (AUD+Gambling group). The DDT value was computed in Microsoft Excel 2016 with a hyperbolic equation fitted for each participant's indifference point $[69,70]$ with the use of the Solver subroutine:

$$
V=\frac{S t d}{1+k X}
$$


where $V$ stands for the value of the indifference point, Std stands for the amount of money available (55,000HUF), $k$ is a fitted parameter which indexes the rate of discounting, and $X$ represents the length of delay. The steepness of the curve $(k)$ is fitted to the subjective value of each point of delay. When the curve is steeper (meaning that the $k$ value is closer to zero), the individual prefers immediate rewards over delayed ones, which represents more impulsive choices.

Independent-samples $t$-tests were used for determining the group differences for continuous variables and Chi-square test was used for categorical variables to compare demographic parameters. Partial correlation analysis was used to reveal the relationship between gambling symptom severity and different facets of impulsivity. Comparison of the two groups' performance on the IGT was determined by Repeated Measures ANOVA and Repeated Measures ANCOVA; due to the results of the Mauchly's Test of Sphericity, the Greenhouse-Geisser correction was applied. To examine the effect of demographic variables, psychopathology symptoms and measures of impulsivity on the likelihood that patients have problem gambling symptoms, binary logistic regressions were used with forward stepwise regression method [71].

Effect sizes were calculated using Cohen's $d$ [72], which is defined as the standardized difference between two means. According to [73], an effect size of $0.2-0.3$ is considered to be a "small" effect size, 0.5 is a "medium" effect and above 0.8 is a "large" effect size.

\section{Results}

\section{Sample characteristics}

More than two-third $(76 \%, \mathrm{n}=79$ out of 103) of the participants were male. The mean age of participants was 45.7 years $(S D=10.35$; age: $21-69)$. In total, $78.7 \%$ of the sample completed secondary education and $21.4 \%$ completed graduate education. Close to one third (31.1\%) of the sample $(\mathrm{n}=32)$ scored 1 or more points on the SOGS with scores ranging between 1 and 14 points (mean $=4.69, \mathrm{SD}=3.5) ; 18$ people categorised as problematic gamblers and 14 as probable pathological gamblers. The two groups did not differ in gender, age, education, IQ, start of alcohol consumption or abstinence during the last 30 days, but the AUD+Gambling group was characterised by more severe alcohol use and longer lifetime alcohol consumption (see Table 1).

Table 1. Demographic, alcohol and gambling related characteristics of the sample.

\begin{tabular}{|c|c|c|c|}
\hline & $\operatorname{AUD}(n=71)$ & AUD+Gambling $(\mathrm{n}=32)$ & \\
\hline Gender $(M \%)$ & $73.2 \%$ & $84.3 \%$ & $\left.X^{2}(1)=1.530, p=0.216\right)^{\mathrm{a}}$ \\
\hline Education\% (primary/secondary/higher) & $5.6 \% / 70.4 \% / 24 \%$ & $12.5 \% / 71.9 \% / 15.6 \%$ & $\left.X^{2}(2)=2.060, p=0.357\right)^{\mathrm{a}}$ \\
\hline Age $(S D)$ & $45.41(9.612)$ & $46.28(11.967)$ & $t(101)=-0.394, p=0.694^{\mathrm{b}}$ \\
\hline Start of alcohol misuse in years $(S D)$ & $25.50(9.337)$ & $22.34(11.449)$ & $t(100)=1.473, p=0.144^{\mathrm{b}}$ \\
\hline Lifetime alcohol consumption in years $(S D)$ & $16.88(9.856)$ & $21.63(11.935)$ & $t(100)=-2.109, p=0.037^{b}$ \\
\hline Abstinence duration during last 30 days $(S D)$ & $22.134(15.571)$ & $17.594(9.641)$ & $t(101)=0.521, p=0.131^{\mathrm{b}}$ \\
\hline WAIS-IV Ttl IQ $(S D)$ & $92.32(14.78)$ & $89.75(15.917)$ & $t(101)=0.798, p=0.427^{\mathrm{b}}$ \\
\hline AUDIT Total $(S D)$ & 23.62(7.316) & $27.48(6.961)$ & $t(100)=-2.489, p=0.014^{\mathrm{b}}$ \\
\hline SCL-90-R GSI (SD) & $0.083(0.064)$ & $0.110(0.074)$ & $t(101)=-1.856, p=0.066^{\mathrm{b}}$ \\
\hline
\end{tabular}

AUD: Alcohol use disorder patient group, AUD+Gambling: Alcohol use disorder patient group with problem or pathological gambling symptoms, WAIS Ttl IQ: Wechsler Adult Intelligence Scale IV total score

${ }^{\text {a }}$ Chi-square test

bIndependent sample $t$-test

https://doi.org/10.1371/journal.pone.0227645.t001 


\section{Exploratory correlation matrix and group differences between gambling symptom severity and demographic variables, psychopathology symptoms and measures of impulsivity}

Partial correlation with age, lifetime alcohol consumption and SCL-90-R GSI as covariates were conducted to explore the associations between these variables, where the severity of gambling symptoms (SOGS scores) showed significant correlation with the BIS Total Score $(\mathrm{r}=0.278, p=0.006)$, while Impulsive aggression measured with the BPAQ Total score $(\mathrm{r}=0.128, p=0.209)$, and neuropsychological measures of impulsivity, as the number of correct responses in the WCST $(r=-0.046, p=0.658)$, the number of total errors in the WCST $(\mathrm{r}=0.054, p=0.602)$, the number of perseverative errors in the WCST $(\mathrm{r}=-0.068, p=0.510)$, the DDT $(\mathrm{r}=-0.118, p=0.254)$, the total win on the IGT $(\mathrm{r}=-0.005, p=0.962)$, the number of advantageous choices on the IGT $(\mathrm{r}=0.065, p=0.529)$, the number of disadvantageous choices on the IGT $(r=-0.065, p=0.529)$ and the IGT net score $(r=0.065, p=0.529)$ did not show significant connection with the severity of gambling symptoms (see S1 Annex).

Based on the associations explored in the correlation matrix, independent sample $t$-tests were conducted to explore group differences in the subscales of the BIS. Fig 2 illustrates that the AUD+Gambling group had higher scores in the BIS Nonplanning $(t(100)=-3.024$, $p=0.003$, Cohen's $d=-0.634)$ and the BIS Total scores $(t(100)=-2.635, p=0.010$, Cohen's $d=$ $-0.555)$, and a tendency toward significance in the BIS Motor Impulsivity $(t(100)=-1.767$, $p=0.080$, Cohen's $d=-0.371$ ).

\section{The effect of demographic variables, psychopathology symptoms and measures of impulsivity on gambling symptoms}

To explore the effect of demographic variables, psychopathology symptoms and measures of impulsivity on gambling symptoms, we performed two binary logistic regressions with

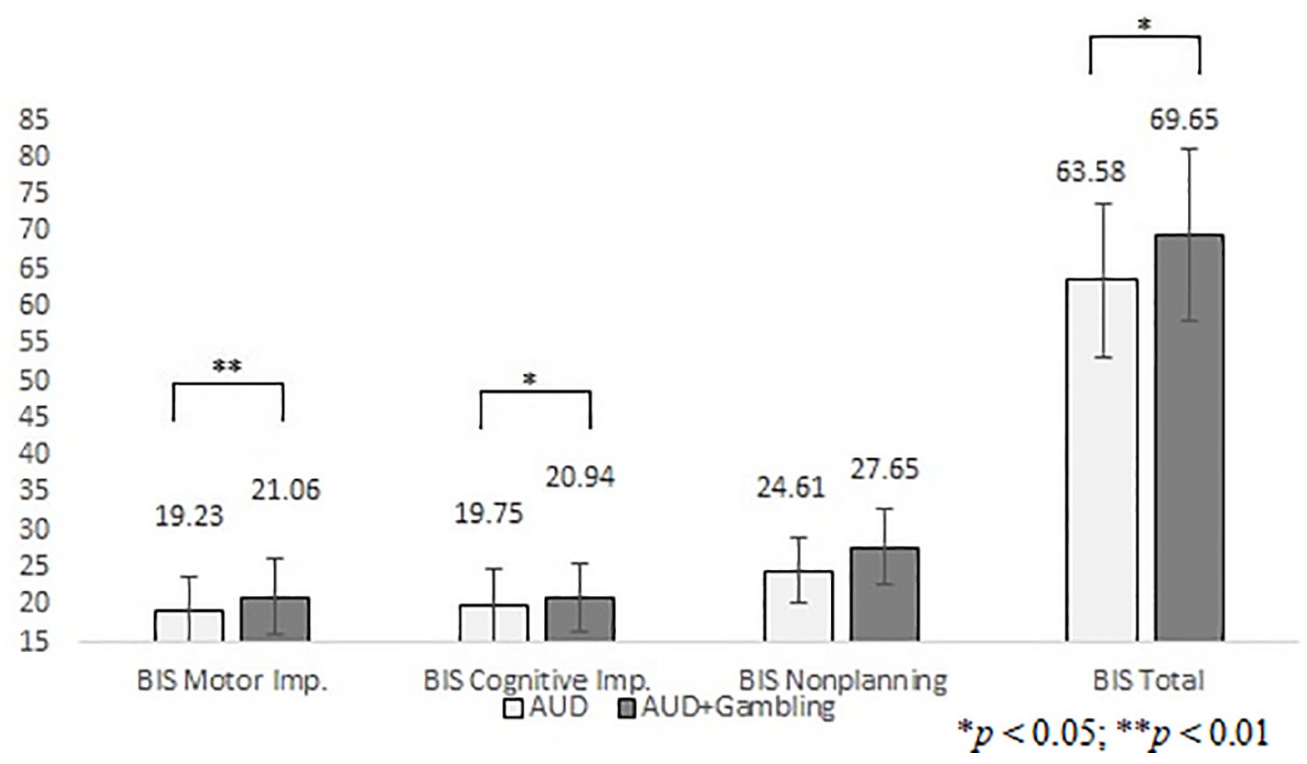

Fig 2. Group differences in Barratt Impulsivity Scale. AUD: chronic alcohol use disorder patients; AUD+Gambling: alcohol use disorder patients with problem or pathological gambling symptoms; BIS Motor Imp.: Barratt Impulsivity Scale Motor Impulsivity subscale; BIS Cognitive Imp.: Barratt Impulsivity Scale Cognitive Impulsivity subscale; BIS Nonplanning: Barratt Impulsivity Scale Nonplanning subscale; BIS Total: Barratt Impulsivity Scale Total score; the columns represent mean values, the error bars standard deviation.

https://doi.org/10.1371/journal.pone.0227645.g002 
forward stepwise regression method with AUD vs. AUD+Gambling as dependent variable. The first binary logistic regression was performed with age, gender, IQ measured by the WAIS-IV and SCL-90-R GSI as covariates. The BPAQ Total score, the BIS Total score, the number of correct responses in the WCST, the number of total errors in the WCST, the number of perseverative errors in the WCST, the DDT, the total win on the IGT, the number of advantageous choices on the IGT, the number of disadvantageous choices on the IGT and the IGT net score on the likelihood that patients have problem gambling symptoms were entered as predictors. Assumption of collinearity was tested and resulted in no indication of multicollinearity (Tolerance below 0.865 and VIF below 3.645 for every variable in the model). The baseline model $(\mathrm{B}=-0.895$, S.E. $=0.220$, Wald $\chi 2(1)=16.507, p \leq 0.001, \mathrm{OR}=0.408)$ had an accuracy of $71.0 \%$ overall percentage. The binary logistic regression model was statistically significant $\left(\chi 2(1)=7.324, p=0.007 ; \mathrm{R}^{2}=0.101\right.$; Hosmer-Lemeshow goodness-of-fit test: $\chi 2(8)=2.703$, $p=0.958)$. Increasing BIS Total score was associated with the increased likelihood of having problem gambling symptoms $(B=0.057$, S.E. $=0.022$, Wald $\chi 2(1)=6.631, p=0.010$, $\mathrm{OR}=1,059,95 \% \mathrm{CI}=1.014-1.105)$ while all the other variables had a non-significant effect in the final model.

In the second binary logistic regression the BIS and BPAQ subscales were also included besides the total scores, namely: BIS Motor Impulsivity Score, BIS Cognitive Impulsivity Score, BIS Nonplanning Score, BPAQ Verbal Aggression Score, BPAQ Physical Aggression, BPAQ Hostility score and BPAQ Anger score. Additionally, the number of correct responses in the WCST, the number of total errors in the WCST, the number of perseverative errors in the WCST, the DDT, the total win on the IGT, the number of advantageous choices on the IGT, the number of disadvantageous choices on the IGT and the IGT net score were included as predictors with age, gender, IQ measured by the WAIS-IV and SCL-90-R GSI as covariates. Assumption of collinearity was tested and resulted in no indication of multicollinearity (Tolerance below 0.819 and VIF below 3.808 for every variable in the model). The baseline model $(\mathrm{B}=-0.895$, S.E. $=0.220$, Wald $\chi 2(1)=16.507, p \leq 0.001, \mathrm{OR}=0.408)$ had an accuracy of $70.0 \%$ overall percentage. The binary logistic regression model was statistically significant $\left(\chi 2(1)=8.914, p=0.003 ; \mathrm{R}^{2}=0.122\right.$; Hosmer-Lemeshow goodness-of-fit test: $\chi 2(7)=9.121$, $p=0.244)$. Increasing BIS Nonplanning score was associated with the increased likelihood of having problem gambling symptoms $(B=0.143$, S.E. $=0.051$, Wald $\chi 2(1)=7.844, p=0.005$, $\mathrm{OR}=1,154,95 \% \mathrm{CI}=1.044-1.275)$, while all the other variables had a non-significant effect in the final model.

\section{Discussion}

Hospitalized patients with long-term chronic alcohol use disorder (AUD) with or without gambling disorder (GD) symptoms were compared on an extensive test battery that assessed four sub-dimensions of impulsivity. The traditional trait concept of impulsivity was measured by the Barratt Impulsivity Scale (BIS), which is the most commonly used internally consistent measure of trait impulsivity in clinical setting. The ability of postponing gratifications or delaying immediate rewards was assessed by the Delay Discounting Task (DDT), which is a widely accepted method for understanding impulsive choices. Impulsive aggression was examined with the Buss-Perry Aggression Questionnaire (BPAQ), and deficits of decision-making and response inhibition, as measurements of cognitive impulsivity, were assessed with the Iowa Gambling Task (IGT) and the Wisconsin Card Sorting Task (WCST).

In our sample, the concurrent AUD and problem or pathological gambling symptoms were associated with more severe alcohol use, longer lifetime alcohol consumption and higher levels of trait impulsivity measured by the BIS. When controlled for age, lifetime alcohol 
consumption and SCL-90-R GSI, GD symptom severity showed significant correlation with trait impulsivity, and only trait impulsivity was related to the increased likelihood of having GD symptoms. Overall, these findings were not due to the result of group differences in age, nor were they mediated by the measured differences in years of alcohol consumption or psychiatric symptom severity evaluated in this study.

Our results indicate that only higher trait impulsivity was associated with comorbid GD symptoms in chronic AUD patients, which was independent of intelligence, age, gender and psychopathological symptom severity. Moreover, the nonplanning aspect of trait impulsivity was associated with the occurrence of comorbid GD symptoms in chronic AUD. This link conforms to previous literature, since in functional imaging studies, the nonplanning dimension of impulsivity measured with the BIS correlated with volumes of the right middle cingulate gyrus, the left anterior cingulate gyrus, left middle frontal gyrus, left middle cingulate gyrus and right orbitofrontal gyrus [74]. Frontal lobe dysfunction is a leading symptom of the alcohol-related impairment in the brain that prolonged AUD causes [75], thus the risk of developing comorbid GD in chronic AUD is especially high.

In our sample of long-term chronic AUD patients, trait impulsivity proved to be a determinant factor, in which AUD patients with comorbid GD symptoms exhibited higher trait impulsivity than patients without them, and trait impulsivity was also associated with more severe substance use symptoms. There is mount evidence on the negative consequences of trait impulsivity in alcohol use and gambling as well, expressed both in clinical and subclinical forms. [76] examined the role of trait impulsivity measured with the BIS in excessive alcohol consumption and alcohol misuse and proved the role of trait impulsivity as a risk factor in alcohol misuse. Concerning diagnosed AUD, several epidemiological [77], cross-sectional $[36,41]$ and longitudinal studies $[78,79]$ thoroughly supported the maladaptive role of higher trait impulsivity in AUD patients. Similarly in GD, [80] compared non-problematic, at-risk and problem gamblers in terms of cognitive impulsivity and found that at-risk and problem gamblers also showed elevated BIS Motor and Attentional Impulsivity. Also in case of clinically diagnosed GD, several studies verified higher trait impulsivity compared to healthy controls [81,82].

Impulsive choice-making is a predominant feature both in AUD and GD. [83] showed a more rapid discounting of delayed rewards among AUD patients, while [25] indicated that GD symptom severity is associated with higher choice impulsivity in a delay discounting task. [84] examined substance abusers with and without problem gambling and indicated that substance abusers with GD symptoms discounted delayed rewards more rapidly than their patients without GD symptoms. Even though it has been previously verified that GD had an additive effect on delay discounting rates, in our study delay discounting was not associated with GD symptoms nor did it increase the likelihood of having GD symptoms in AUD patients. A reason for that may lie in the fact that patients suffering from addictive disorders with or without GD symptoms are documented to discount delayed rewards more rapidly than healthy controls, thus addictive disorders themselves are associated with higher discounting rates $[85,86]$.

Previous studies have explored that poor response inhibition - that may be related to impulsive aggression-is affected by acute alcohol consumption [87-89] and chronic alcohol abuse and dependence as well $[90,91]$. The control of response inhibition is mediated by prefrontal/orbito-frontal and limbic/thalamic cortical circuits, and the impairment of these interconnected circuitries may induce excessive aggressive responding, thus impulsive aggression $[92,93]$. In our study, we measured impulsive aggression with the BPAQ, which is a widely used self-evaluation test in clinical setting for assessing trait aggression. In our sample, BPAQ total scores correlated with gambling symptom severity, which conform to current scientific 
results. Similarly, growing number of studies have reported a link between gambling and aggressive behaviour [94]. While in a longitudinal study of males tested at age 12, 15 and 18, [95] found that early aggressive behaviour measured with the BPAQ leads to the increase of alcohol consumption, but they did not find that alcohol use have led to later aggressive behaviour. Similarly, the presence of aggressive impulses has been well-documented in clinical populations of AUD and GD as well [96,97].

Risky decision-making and response inhibition as forms of impulsivity have been hypothesised to play a central role in addictive processes. Gambling tasks with risks and rewards like the IGT and tasks measuring executive (frontal lobe) functions like the WCST have been widely used to assess decision-making capacities and deficits in response inhibition in individuals with AUD and GD. Compared to healthy controls, AUD and GD patients both exhibit deficits on the IGT, meaning that they more frequently choose the larger immediate reward despite the presence of a larger concomitant punishment [98-101]. Similarly, it has also been documented that in case of chronic long-term alcohol consumption the performance on executive function tests like the WCST deteriorated [102,103]; also a previous study indicated that GD patients had more perseverative errors on the WCST, which is another measure of cognitive flexibility [104]. Our results do not conform to these previous findings, since in our sample we could not identify differences on the IGT or the WCST between chronic AUD patients with or without GD symptoms, nor did these test results contribute to the likelihood of having GD symptoms. The reason behind the lack of difference between long-term AUD and AUD with comorbid GD symptoms might be reasoned with the effects of chronic alcohol consumption in those cortical regions that play essential role in response inhibition and decision-making $[41,105,106]$, which in this case did not result in the even higher deficit of the neurocognitive performance of AUD patients with symptoms of GD compared to patients with only AUD.

Regarding the lack of differences in other aspects of impulsivity measured in this study, meta-analyses $[18,19]$ indicate that impulsivity is not a unitary construct and it has different manifestations in AUD and GD compared to healthy populations. Ioannidis et al. (2019) argued that clinical and even subclinical GD is characterized by general disfunction in inhibitory control, thus impulsive cognitive disfunction, while another meta-analysis [71] established that both AUD and GD show impairment in cognitive impulsivity, GD patients exhibiting even higher impairment on impulsive decision-making.

However, a few limitations need to be taken into account when interpreting the results of this study. Since impulsivity is regarded as a complex and multifactorial phenomenon, there is no clear-cut consensus for defining and operationalizing each component of it, even the number of components and their separability are questioned. We operationalized impulsivity by neuropsychological and self-measurement tests assessing four domains: trait impulsivity, choice impulsivity, impulsive aggression and impulsive decision-making; thus, the present study is limited by this notion.

Additionally, in the present study, impulsive aggression was measured by the Buss-Perry Aggression Questionnaire (BPAQ), which is related to impulsiveness; however, it does not explicitly measure impulsivity, since it includes items of premeditated antisocial behaviour and hostility. Moreover, considering the cross-sectional nature of the current study, conclusions concerning causality between comorbid AUD and GD symptoms and distinct facets of impulsivity cannot be drawn. In this study, we could only establish a link between longer lifetime alcohol consumption, more severe alcohol consumption and heightened trait impulsivity in AUD patients with comorbid GD symptoms compared to sole AUD. Since the prolonged misuse of alcohol leads to impulsive actions across one's life course, and this influence both objective and subjective measures of impulsivity. Future research would benefit from the 
longitudinal evaluation of the different aspects of impulsivity in chronic AUD populations. Taking into consideration its different presentations in AUD comorbid with GD symptoms may contribute to clearing directions for providing target-specific and effective treatment approaches.

Supplementary information for this manuscript can be found online: https://dx.doi.org/10. 6084/m9.figshare.11473296

\section{Supporting information}

S1 Annex. Correlation matrix for study variables.

(DOCX)

\section{Acknowledgments}

Zsolt Demetrovics was supported by the Hungarian National Research, Development and Innovation Office (NKFIH-1157-8/2019-DT, KKP126835).

Bálint Andó was supported by the Geza Hetenyi Grant (Grant Number: SZTE-ÁOK-KKA2019-HG).

Special thanks to Sándor Rózsa for providing the WAIS-IV assessment tool and the certification for its application.

\section{Author Contributions}

Conceptualization: Ildikó Kovács, Ildikó Demeter, Zoltán Janka, Zsolt Demetrovics, Bálint Andó.

Data curation: Ildikó Kovács.

Formal analysis: Ildikó Kovács, Zsolt Demetrovics, Aniko Maraz, Bálint Andó.

Investigation: Ildikó Kovács, Ildikó Demeter, Bálint Andó.

Methodology: Ildikó Kovács, Ildikó Demeter, Zoltán Janka, Zsolt Demetrovics, Aniko Maraz, Bálint Andó.

Project administration: Zoltán Janka, Aniko Maraz, Bálint Andó.

Software: Ildikó Kovács.

Supervision: Ildikó Demeter, Zoltán Janka, Zsolt Demetrovics, Aniko Maraz, Bálint Andó.

Writing - original draft: Ildikó Kovács, Zsolt Demetrovics, Aniko Maraz, Bálint Andó.

Writing - review \& editing: Ildikó Kovács, Ildikó Demeter, Zoltán Janka, Zsolt Demetrovics, Aniko Maraz, Bálint Andó.

\section{References}

1. Hasin DS, Grant BF. The National Epidemiologic Survey on Alcohol and Related Conditions (NESARC) Waves 1 and 2: review and summary of findings. Soc Psychiatry Psychiatr Epidemiol. 2015; 50(11):1609-40. https://doi.org/10.1007/s00127-015-1088-0 PMID: 26210739

2. World Health Organization, Management of Substance Abuse Team, World Health Organization. Global status report on alcohol and health 2018. [Internet]. 2018 [cited 2018 Nov 15]. Available from: http://www.who.int/substance_abuse/publications/global_alcohol_report/en/

3. Cunningham-Williams RM, Cottler LB, Compton WM, Spitznagel EL. Taking chances: problem gamblers and mental health disorders-results from the St. Louis Epidemiologic Catchment Area Study. Am J Public Health. 1998; 88(7):1093-6. https://doi.org/10.2105/ajph.88.7.1093 PMID: 9663161 
4. Manning V, Dowling NA, Lee S, Rodda S, Garfield JBB, Volberg R, et al. Problem gambling and substance use in patients attending community mental health services. J Behav Addict. 2017; 6(4):67888. https://doi.org/10.1556/2006.6.2017.077 PMID: 29254361

5. Feigelman W, Wallisch LS, Lesieur HR. Problem gamblers, problem substance users, and dual-problem individuals: An epidemiological study. Am J Public Health. 1998; 88(3):467-70. https://doi.org/10. 2105/ajph.88.3.467 PMID: 9518986

6. Stinchfield R, Kushner MG, Winters KC. Alcohol use and prior substance abuse treatment in relation to gambling problem severity and gambling treatment outcome. J Gambl Stud. 2005; 21(3):273-97. https://doi.org/10.1007/s10899-005-3100-1 PMID: 16134009

7. Petry NM, Stinson FS, Grant BF. Comorbidity of DSM-IV pathological gambling and other psychiatric disorders: results from the National Epidemiologic Survey on Alcohol and Related Conditions. J Clin Psychiatry. 2005; 66(5):564-74. https://doi.org/10.4088/jcp.v66n0504 PMID: 15889941

8. Lorains FK, Cowlishaw S, Thomas SA. Prevalence of comorbid disorders in problem and pathological gambling: systematic review and meta-analysis of population surveys. Addict Abingdon Engl. 2011; 106(3):490-8.

9. Daghestani AN, Elenz E, Crayton JW. Pathological gambling in hospitalized substance abusing veterans. J Clin Psychiatry. 1996; 57(8):360-3. PMID: 8752019

10. Lesieur HR, Rosenthal RJ. Pathological gambling: A review of the literature (prepared for the American Psychiatric Association task force on DSM-IV committee on disorders of impulse control not elsewhere classified). J Gambl Stud. 1991; 7(1):5-39. https://doi.org/10.1007/BF01019763 PMID: 24242968

11. Slutske WS, Eisen S, True WR, Lyons MJ, Goldberg J, Tsuang M. Common genetic vulnerability for pathological gambling and alcohol dependence in men. Arch Gen Psychiatry. 2000; 57(7):666-73. https://doi.org/10.1001/archpsyc.57.7.666 PMID: 10891037

12. Bottesi G, Ghisi M. Pathological gambling: Compulsive -impulsive spectrum disorder, behavioural addiction or both? Phenotypic and endophenotypic evidence. Psychopathol Rev. 2014; 1(1):2-25.

13. Salvatore JE, Gottesman II, Dick DM. Endophenotypes for alcohol use disorder: An update on the field. Curr Addict Rep. 2015; 2(1):76-90. https://doi.org/10.1007/s40429-015-0046-y PMID: 26236574

14. Buja A, Lion C, Scioni M, Vian $P$, Genetti B, Vittadello $F$, et al. SOGS-RA gambling scores and substance use in adolescents. J Behav Addict. 2017; 6(3):425-33. https://doi.org/10.1556/2006.6.2017. 043 PMID: 28783970

15. Vitaro F, Arseneault L, Tremblay RE. Impulsivity predicts problem gambling in low SES adolescent males. Addict Abingdon Engl. 1999; 94(4):565-75.

16. Verdejo-García A, Lawrence AJ, Clark L. Impulsivity as a vulnerability marker for substance-use disorders: review of findings from high-risk research, problem gamblers and genetic association studies. Neurosci Biobehav Rev. 2008; 32(4):777-810. https://doi.org/10.1016/j.neubiorev.2007.11.003 PMID: 18295884

17. Rochat L, Billieux J, Gagnon J, Van der Linden M. A multifactorial and integrative approach to impulsivity in neuropsychology: insights from the UPPS model of impulsivity. J Clin Exp Neuropsychol. 2018; 40(1):45-61. https://doi.org/10.1080/13803395.2017.1313393 PMID: 28398126

18. Stephan RA, Alhassoon OM, Allen KE, Wollman SC, Hall M, Thomas WJ, et al. Meta-analyses of clinical neuropsychological tests of executive dysfunction and impulsivity in alcohol use disorder. Am J Drug Alcohol Abuse. 2017; 43(1):24-43. https://doi.org/10.1080/00952990.2016.1206113 PMID: 27712350

19. Ioannidis K, Hook R, Wickham K, Grant JE, Chamberlain SR. Impulsivity in gambling disorder and problem gambling: A meta-analysis. Am J Drug Alcohol Abuse. 2019; 43(1):24-43.

20. Mitchell MR, Potenza MN. Addictions and personality traits: Impulsivity and related constructs. Curr Behav Neurosci Rep. 2014; 1(1):1-12. https://doi.org/10.1007/s40473-013-0001-y PMID: 24772382

21. Perry JL, Carroll ME. The role of impulsive behavior in drug abuse. Psychopharmacology (Berl). 2008; 200(1):1-26.

22. Everitt BJ, Robbins TW. Neural systems of reinforcement for drug addiction: from actions to habits to compulsion. Nat Neurosci. 2005; 8(11):1481-9. https://doi.org/10.1038/nn1579 PMID: 16251991

23. Fein G, Bachman L, Fisher S, Davenport L. Cognitive impairments in abstinent alcoholics. West J Med. 1990; 152(5):531-7. PMID: 2190421

24. Harding AJ, Wong A, Svoboda M, Kril JJ, Halliday GM. Chronic alcohol consumption does not cause hippocampal neuron loss in humans. Hippocampus. 1997; 7(1):78-87. https://doi.org/10.1002/(SICl) 1098-1063(1997)7:1<78::AID-HIPO8>3.0.CO;2-3 PMID: 9138671 
25. Alessi SM, Petry NM. Pathological gambling severity is associated with impulsivity in a delay discounting procedure. Behav Processes. 2003; 64(3):345-54. https://doi.org/10.1016/s0376-6357(03)001505 PMID: 14580703

26. Bechara A, Damasio AR, Damasio H, Anderson SW. Insensitivity to future consequences following damage to human prefrontal cortex. Cognition. 1994; 50(1-3):7-15. https://doi.org/10.1016/00100277(94)90018-3 PMID: 8039375

27. Hodgins DC, Holub A. Components of impulsivity in gambling disorder. Int J Ment Health Addict. 2015; 13(6):699-711. https://doi.org/10.1007/s11469-015-9572-z PMID: 26568706

28. Mitchell JM, Fields HL, D'Esposito M, Boettiger CA. Impulsive responding in alcoholics. Alcohol Clin Exp Res. 2005; 29(12):2158-69. https://doi.org/10.1097/01.alc.0000191755.63639.4a PMID: 16385186

29. Dussault F, Brendgen M, Vitaro F, Wanner B, Tremblay RE. Longitudinal links between impulsivity, gambling problems and depressive symptoms: a transactional model from adolescence to early adulthood. J Child Psychol Psychiatry. 2011; 52(2):130-8. https://doi.org/10.1111/j.1469-7610.2010. 02313.x PMID: 20854365

30. Hentges RF, Shaw DS, Wang M-T. Early childhood parenting and child impulsivity as precursors to aggression, substance use, and risky sexual behavior in adolescence and early adulthood. Dev Psychopathol. 2018; 30(4):1305-19. https://doi.org/10.1017/S0954579417001596 PMID: 29151377

31. Jacob L, Haro JM, Koyanagi A. Relationship between attention-deficit hyperactivity disorder symptoms and problem gambling: A mediation analysis of influential factors among 7,403 individuals from the UK. J Behav Addict. 2018; 7(3):781-91. https://doi.org/10.1556/2006.7.2018.72 PMID: 30238788

32. McCarthy DM, Niculete ME, Treloar HR, Morris DH, Bartholow BD. Acute alcohol effects on impulsivity: Associations with drinking and driving behavior. Addict Abingdon Engl. 2012; 107(12):2109-14.

33. Berlin HA, Hollander E. Understanding the differences between impulsivity and compulsivity. Psychiatr Times. 2008; 25(8):58.

34. Charney DA, Zikos E, Gill KJ. Early recovery from alcohol dependence: Factors that promote or impede abstinence. J Subst Abuse Treat. 2010; 38(1):42-50. https://doi.org/10.1016/j.jsat.2009.06. 002 PMID: 19632079

35. Moeller FG, Barratt ES, Dougherty DM, Schmitz JM, Swann AC. Psychiatric Aspects of Impulsivity. Am J Psychiatry [Internet]. 2001 Nov 1 [cited 2018 Dec 18]; Available from: https://ajp. psychiatryonline.org/doi/abs/10.1176/appi.ajp.158.11.1783

36. Evren C, Durkaya M, Evren B, Dalbudak E, Cetin R. Relationship of relapse with impulsivity, novelty seeking and craving in male alcohol-dependent inpatients. Drug Alcohol Rev. 2012; 31(1):81-90. https://doi.org/10.1111/j.1465-3362.2011.00303.x PMID: 21450046

37. Aragay N, Barrios M, Ramirez-Gendrau I, Garcia-Caballero A, Garrido G, Ramos-Grille I, et al. Impulsivity profiles in pathological slot machine gamblers. Compr Psychiatry. 2018; 83:79-83. https://doi. org/10.1016/j.comppsych.2018.03.008 PMID: 29625378

38. Stevens AK, Littlefield AK, Talley AE, Brown JL. Do individuals higher in impulsivity drink more impulsively? A pilot study within a high risk sample of young adults. Addict Behav. 2017; 65:147-53. https:// doi.org/10.1016/j.addbeh.2016.10.026 PMID: 27816040

39. Yakovenko I, Fortgang R, Prentice J, Hoff RA, Potenza MN. Correlates of frequent gambling and gambling-related chasing behaviors in individuals with schizophrenia-spectrum disorders. J Behav Addict. 2018; 7(2):375-83. https://doi.org/10.1556/2006.7.2018.31 PMID: 29788756

40. Lawrence AJ, Luty J, Bogdan NA, Sahakian BJ, Clark L. Problem gamblers share deficits in impulsive decision-making with alcohol-dependent individuals. Addict Abingdon Engl. 2009; 104(6):1006-15.

41. Goudriaan AE, Oosterlaan J, de Beurs $E$, van den Brink W. Decision making in pathological gambling: A comparison between pathological gamblers, alcohol dependents, persons with Tourette syndrome, and normal controls. Cogn Brain Res. 2005; 23(1):137-51.

42. Bottesi G, Ghisi M, Ouimet AJ, Tira MD, Sanavio E. Compulsivity and impulsivity in pathological gambling: Does a dimensional-transdiagnostic approach add clinical utility to DSM-5 classification? J Gambl Stud. 2015; 31(3):825-47. https://doi.org/10.1007/s10899-014-9470-5 PMID: 24863627

43. Kovács I, Richman MJ, Janka Z, Maraz A, Andó B. Decision making measured by the lowa Gambling Task in alcohol use disorder and gambling disorder: a systematic review and meta-analysis. Drug Alcohol Depend. 2017; 181:152-61. https://doi.org/10.1016/j.drugalcdep.2017.09.023 PMID: 29055269

44. Eysenck SBG, Pearson PR, Easting G, Allsopp JF. Age norms for impulsiveness, venturesomeness and empathy in adults. Personal Individ Differ. 1985; 6(5):613-9. 
45. Patton JH, Stanford MS, Barratt ES. Factor structure of the Barratt Impulsiveness Scale. J Clin Psychol. 1995; 51(6):768-74. https://doi.org/10.1002/1097-4679(199511)51:6<768::aidjclp2270510607>3.0.co;2-1 PMID: 8778124

46. Ainslie G. Specious reward: A behavioral theory of impulsiveness and impulse control. Psychol Bull. 1975; 82(4):463-96. https://doi.org/10.1037/h0076860 PMID: 1099599

47. Blair RJR. The neurobiology of impulsive aggression. J Child Adolesc Psychopharmacol. 2016; 26 (1):4-9. https://doi.org/10.1089/cap.2015.0088 PMID: 26465707

48. Franken IHA, van Strien JW, Nijs I, Muris P. Impulsivity is associated with behavioral decision-making deficits. Psychiatry Res. 2008; 158(2):155-63. https://doi.org/10.1016/j.psychres.2007.06.002 PMID: 18215765

49. Logan GD. On the ability to inhibit thought and action: A users' guide to the stop signal paradigm. Inhibitory processes in attention, memory, and language. Abil Inhib Thought Action Users Guide Stop Signal Paradigm. 1994;189-239.

50. Paksi B, Demetrovics Z, Magi A, Felvinczi K. [The methodology and sample description of the National Survey on Addiction Problems in Hungary 2015 (NSAPH 2015)]. Neuropsychopharmacol Hung. 2017; 19(2):55-85. PMID: 28918416

51. Buss AH, Perry M. The aggression questionnaire. J Pers Soc Psychol. 1992; 63(3):452-9. https://doi. org/10.1037//0022-3514.63.3.452 PMID: 1403624

52. Gerevich J, Bácskai E, Czobor $P$. The generalizability of the Buss-Perry Aggression Questionnaire. Int J Methods Psychiatr Res. 2007; 16(3):124-36. https://doi.org/10.1002/mpr.221 PMID: 17849418

53. Bechara A, Damasio H, Tranel D, Damasio AR. Deciding advantageously before knowing the advantageous strategy. Science. 1997; 275(5304):1293-5. https://doi.org/10.1126/science.275.5304.1293 PMID: 9036851

54. Grant DA, Berg EA. A behavioral analysis of degree of reinforcement and ease of shifting to new responses in a Weigl-type card-sorting problem. J Exp Psychol. 1948; 38(4):404-11. https://doi.org/ 10.1037/h0059831 PMID: 18874598

55. Berg EA. A simple objective technique for measuring flexibility in thinking. J Gen Psychol. 1948; 39:15-22. https://doi.org/10.1080/00221309.1948.9918159 PMID: 18889466

56. Piper BJ, Mueller ST, Geerken AR, Dixon KL, Kroliczak G, Olsen RHJ, et al. Reliability and validity of neurobehavioral function on the Psychology Experimental Building Language test battery in young adults. PeerJ. 2015; 3:e1460. https://doi.org/10.7717/peerj.1460 PMID: 26713233

57. Wechsler D. Wechsler Adult Intelligence Scale ( 4th ed.). San Antonio, TX: Psychological Corporation; 2008.

58. Rózsa S, Kő N. A Wechsler intelligenciateszttel szerzett nemzetközi eredmények áttekintése. In: A WISC-IV gyermek intelligenciateszt magyar kézikönyve Hazai tapasztalatok, vizsgálati eredmények és normák. Budapest: OS Hungary Tesztfejlesztő Kft.; 2008. p. 9-16.

59. Butler SF, Budman SH, Goldman RJ, Newman FL, Beckley KE, Trottier D, et al. Initial validation of a computer-administered Addiction Severity Index: the ASI-MV. Psychol Addict Behav J Soc Psychol Addict Behav. 2001; 15(1):4-12.

60. Rácz J, Pogány C, Máthé-Árvay N. Az EuropASI (Addikció Súlyossági Index) magyar nyelvű változatának reliabilitás- és validitásvizsgálata. Magy Pszichol Szle. 2002; 57(4):587-603.

61. Lesieur HR, Blume SB. The South Oaks Gambling Screen (SOGS): a new instrument for the identification of pathological gamblers. Am J Psychiatry. 1987; 144(9):1184-8. https://doi.org/10.1176/ajp. 144.9.1184 PMID: 3631315

62. Gyollai $A$, Urbán $R$, Kun $B$, Paksi $B$, Arnold $P$, Balázs $H$, et al. Problémás és patológiás szerencsejáték Magyarországon: a South Oaks szerencsejáték kérdoiv magyar verziójának (SOGS-HU) hazai alkalmazása. Psychiatr Hung. 2011; 26(4):230-40. PMID: 22058255

63. Saunders JB, Aasland OG, Babor TF, de la Fuente JR, Grant M. Development of the Alcohol Use Disorders Identification Test (AUDIT): WHO Collaborative Project on Early Detection of Persons with Harmful Alcohol Consumption—II. Addict Abingdon Engl. 1993; 88(6):791-804.

64. Gerevich J, Bácskai E, Rózsa S. Prevalence of hazardous alcohol use. Psychiatr Hung. 2006; 21 (1):45-56. PMID: 16783031

65. Derogatis LR. SCL-90-R Administration, Scoring and Procedures Manual II for the Revised Version and Other Instruments of the Psychopathology Rating Scale Series. Towson, MD: Clinical Psychometric Research; 1986. 61 p.

66. Urbán R, Arrindell WA, Demetrovics Z, Unoka Z, Timman R. Cross-cultural confirmation of bi-factor models of a symptom distress measure: Symptom Checklist-90-Revised in clinical samples. Psychiatry Res. 2016; 239:265-74. https://doi.org/10.1016/j.psychres.2016.03.039 PMID: 27039011 
67. Urbán R, Kun B, Farkas J, Paksi B, Kökönyei G, Unoka Z, et al. Bifactor structural model of symptom checklists: SCL-90-R and Brief Symptom Inventory (BSI) in a non-clinical community sample. Psychiatry Res. 2014; 216(1):146-54. https://doi.org/10.1016/j.psychres.2014.01.027 PMID: 24524946

68. Corp IBM. IBM SPSS Statistics for Windows. Armonk, NY: IBM Corp.; 2016.

69. Mazur JE. An adjusting procedure for studying delayed reinforcement. In: The effect of delay and of intervening events on reinforcement value. Hillsdale, NJ, US: Lawrence Erlbaum Associates, Inc; 1987. p. 55-73. (Quantitative analyses of behavior, Vol. 5.).

70. Mitchell SH. Measures of impulsivity in cigarette smokers and non-smokers. Psychopharmacology (Berl). 1999; 146(4):455-64.

71. Kovács I, Demeter I, Janka Z, Demetrovics Z, Maraz A, Andó B. Dataset for manuscript entitled 'Different aspects of impulsivity in chronic alcohol use disorder with and without comorbid problem gambling' [Internet]. 2019 [cited 2019 Aug 24]. Available from: https://dx.doi.org/10.6084/m9.figshare.11473296

72. Rosnow RL, Rosenthal R, Rubin DB. Contrasts and correlations in effect-size estimation. Psychol Sci. 2000; 11(6):446-53. https://doi.org/10.1111/1467-9280.00287 PMID: 11202488

73. Cohen J. Statistical power analysis for the behavioral sciences. Hillsdale, N.J.: L. Erlbaum Associates; 1988.

74. Cho SS, Pellecchia G, Aminian K, Ray N, Segura B, Obeso I, et al. Morphometric correlation of impulsivity in medial prefrontal cortex. Brain Topogr. 2013; 26(3):479-87. https://doi.org/10.1007/s10548012-0270-x PMID: 23274773

75. Sullivan EV, Harris RA, Pfefferbaum A. Alcohol's effects on brain and behavior. Alcohol Res Health. 2010; 33(1-2):127-43. PMID: 23579943

76. Keough MT O'Connor RM. Interactive Effects of the BIS and the BAS on trajectories of alcohol misuse after university graduation. Subst Abuse Res Treat. 2016; 9(Suppl 1):33-40.

77. Johnson SL, Turner RJ, Iwata N. BIS/BAS Levels and psychiatric disorder: An epidemiological study. J Psychopathol Behav Assess. 2003; 25(1):25-36.

78. Evren C, Yilmaz A, Can Y, Bozkurt M, Evren B. EPA-0489-Status of impulsivity in 12 month followup among male alcohol dependent inpatients. Eur Psychiatry. 2014; 29:1. https://doi.org/10.1016/j. eurpsy.2013.08.001

79. Rubio G, Jiménez M, Rodríguez-Jiménez R, Martínez I, Ávila C, Ferre F, et al. The role of behavioral impulsivity in the development of alcohol dependence: A 4-Year Follow-Up Study. Alcohol Clin Exp Res. 2008; 32(9):1681-7. https://doi.org/10.1111/j.1530-0277.2008.00746.x PMID: 18631324

80. Yan W-S, Zhang R-R, Lan Y, Li Y-H, Sui N. Comparison of impulsivity in non-problem, at-risk and problem gamblers. Sci Rep [Internet]. 2016 Dec 15 [cited 2018 Dec 20];6. Available from: https://www. ncbi.nlm.nih.gov/pmc/articles/PMC5156948/

81. Choi J-S, Kim HS, Kim G-Y, Jeon Y, Park SM, Lee J-Y, et al. Similarities and differences among Internet gaming disorder, gambling disorder and alcohol use disorder: A focus on impulsivity and compulsivity. J Behav Addict. 2014; 3(4):246-53. https://doi.org/10.1556/JBA.3.2014.4.6 PMID: 25592310

82. Lee JY, Park SM, Kim YJ, Kim DJ, Choi S-W, Kwon JS, et al. Resting-state EEG activity related to impulsivity in gambling disorder. J Behav Addict. 2017; 6(3):387-95. https://doi.org/10.1556/2006.6 2017.055 PMID: 28856896

83. Petry NM. Delay discounting of money and alcohol in actively using alcoholics, currently abstinent alcoholics, and controls. Psychopharmacology (Berl). 2001; 154(3):243-50.

84. Petry NM, Casarella $T$. Excessive discounting of delayed rewards in substance abusers with gambling problems. Drug Alcohol Depend. 1999; 56(1):25-32. https://doi.org/10.1016/s0376-8716(99)00010-1 PMID: 10462089

85. Kirby KN, Petry NM, Bickel WK. Heroin addicts have higher discount rates for delayed rewards than non-drug-using controls. J Exp Psychol Gen. 1999; 128(1):78-87. https://doi.org/10.1037//0096-3445. 128.1.78 PMID: 10100392

86. Madden GJ, Petry NM, Badger GJ, Bickel WK. Impulsive and self-control choices in opioid-dependent patients and non-drug-using control participants: drug and monetary rewards. Exp Clin Psychopharmacol. 1997; 5(3):256-62. https://doi.org/10.1037//1064-1297.5.3.256 PMID: 9260073

87. Fillmore MT, Blackburn J. Compensating for alcohol-induced impairment: alcohol expectancies and behavioral disinhibition. J Stud Alcohol. 2002; 63(2):237-46. https://doi.org/10.15288/jsa.2002.63.237 PMID: 12033701

88. Fillmore MT, Marczinski CA, Bowman AM. Acute tolerance to alcohol effects on inhibitory and activational mechanisms of behavioral control. J Stud Alcohol. 2005; 66(5):663-72. https://doi.org/10. 15288/jsa.2005.66.663 PMID: 16331852 
89. Marczinski CA, Fillmore MT. Compensating for alcohol-induced impairment of control: effects on inhibition and activation of behavior. Psychopharmacology (Berl). 2005; 181(2):337-46.

90. Hildebrandt $\mathrm{H}$, Brokate $\mathrm{B}$, Eling $\mathrm{P}$, Lanz $\mathrm{M}$. Response shifting and inhibition, but not working memory, are impaired after long-term heavy alcohol consumption. Neuropsychology. 2004; 18(2):203-11. https://doi.org/10.1037/0894-4105.18.2.203 PMID: 15099142

91. Kamarajan C, Porjesz B, Jones KA, Choi K, Chorlian DB, Padmanabhapillai A, et al. Alcoholism is a disinhibitory disorder: neurophysiological evidence from a Go/No-Go task. Biol Psychol. 2005; 69 (3):353-73. https://doi.org/10.1016/j.biopsycho.2004.08.004 PMID: 15925035

92. Kringelbach ML. The human orbitofrontal cortex: linking reward to hedonic experience. Nat Rev Neurosci. 2005; 6(9):691-702. https://doi.org/10.1038/nrn1747 PMID: 16136173

93. Metzger CD, Eckert U, Steiner J, Sartorius A, Buchmann JE, Stadler J, et al. High field FMRI reveals thalamocortical integration of segregated cognitive and emotional processing in mediodorsal and intralaminar thalamic nuclei. Front Neuroanat. 2010; 4:138. https://doi.org/10.3389/fnana.2010.00138 PMID: 21088699

94. Parke A, Griffiths MD. Aggressive behaviour in adult slot machine gamblers: A qualitative observational study. Int J Ment Health Addict. 2005; 2(50-58).

95. White HR, Brick J, Hansell S. A longitudinal investigation of alcohol use and aggression in adolescence. J Stud Alcohol Suppl. 1993; 11:62-77. https://doi.org/10.15288/jsas.1993.s11.62 PMID: 8410965

96. Korman L, Collins J, Littman-Sharp N, Skinner W, McMain S, Mercado V. Randomized control trial of an integrated therapy for comorbid anger and gambling. Psychother Res J Soc Psychother Res. 2008; 18(4):454-65.

97. McPherson A, Martin C. A contemporary review of the alcohol/aggression relationship and the BussPerry Aggression Questionnaire for use in an alcohol dependent population. J Aggress Confl Peace Res. 2010; 2(1):45-56.

98. Cavedini P, Riboldi G, Keller R, D'Annucci A, Bellodi L. Frontal lobe dysfunction in pathological gambling patients. Biol Psychiatry. 2002; 51(4):334-41. https://doi.org/10.1016/s0006-3223(01)01227-6 PMID: 11958785

99. Cordovil De Sousa Uva M, Luminet O, Cortesi M, Constant E, Derely M, De Timary P. Distinct effects of protracted withdrawal on affect, craving, selective attention and executive functions among alcoholdependent patients. Alcohol Alcohol Oxf Oxfs. 2010; 45(3):241-6.

100. Forbush KT, Shaw M, Graeber MA, Hovick L, Meyer VJ, Moser DJ, et al. Neuropsychological characteristics and personality traits in pathological gambling. CNS Spectr. 2008; 13(4):306-15. https://doi. org/10.1017/s1092852900016424 PMID: 18408650

101. Murray DE, Durazzo TC, Mon A, Schmidt TP, Meyerhoff DJ. Brain perfusion in polysubstance users: relationship to substance and tobacco use, cognition, and self-regulation. Drug Alcohol Depend. 2015; 150:120-8. https://doi.org/10.1016/j.drugalcdep.2015.02.022 PMID: 25772434

102. Guillot CR, Fanning JR, Bullock JS, McCloskey MS, Berman ME. Effects of alcohol on tests of executive functioning in men and women: A dose response examination. Exp Clin Psychopharmacol. 2010; 18(5):409-17. https://doi.org/10.1037/a0021053 PMID: 20939644

103. Houston RJ, Derrick J, Leonard K, Testa M, Quigley B, Kubiak A. Effects of heavy drinking on executive cognitive functioning in a community sample. Addict Behav. 2014; 39(1):345-9. https://doi.org/10. 1016/j.addbeh.2013.09.032 PMID: 24459697

104. Potenza MN, Kosten TR, Rounsaville BJ. Pathological gambling. JAMA. 2001; 286(2):141-4. https:// doi.org/10.1001/jama.286.2.141 PMID: 11448261

105. Lawrence AJ, Luty J, Bogdan NA, Sahakian BJ, Clark L. Impulsivity and response inhibition in alcohol dependence and problem gambling. Psychopharmacology (Berl). 2009; 207(1):163-72.

106. Mackey S, Allgaier N, Chaarani B, Spechler P, Orr C, Bunn J, et al. Mega-analysis of gray matter volume in substance dependence: General and substance-specific regional effects. Am J Psychiatry. 2018;appiajp201817040415. 